\title{
Conspicuous Invisibility \\ Votive Offerings from Female Dedicators on the Athenian Acropolis
}

Stacey Wellington

A thesis submitted to the Victoria University of Wellington in fulfilment of the requirements for the degree of Master of Arts in Classical Studies

Victoria University of Wellington

2018 



\section{Contents}

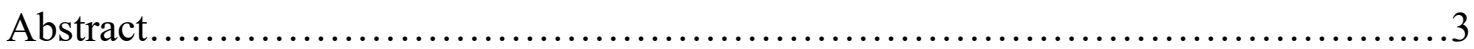

Acknowledgements.......................................................... 5

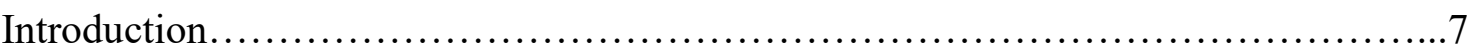

Chapter One: The context and evidence

1.1 Some issues with studying women in antiquity......................... 9

1.1.1 Status and 'respectability'...................................11

1.1.2 Public and private spheres....................................13

1.2 The nature of votive offerings..................................... 18

1.3 The evidence....................................................... 1

Chapter Two: The andronymic as a statement of female citizenship

2.1 Naming Athenian women........................................... 28

2.2 Questions of demographic............................................. 31

2.3 Possible motivations for using the andronymic...........................38

2.3.1 Adherence to ideology........................................ 38

2.3.2 Identification.............................................. 40

2.3.3 Increased value of female citizenship.........................44

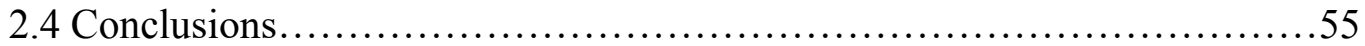

Chapter Three: Veiled control over resources

3.1 More than just "transmitters of property" ..............................56

3.2 Legal restrictions...................................................5

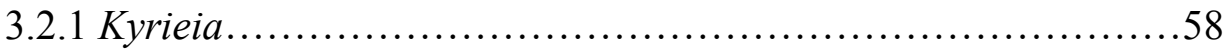

3.2.2 Disposal..................................................61

3.3 Concepts of ownership...........................................63

3.4 Means of income and dedications as disposal............................66

3.4.1. 'Feminine' property: the dowry and pherne ...................67

3.4.2 Paid work and priesthoods................................... 70

3.4.3 Paid work continued: first-offerings..........................78

3.5 Conclusions..................................................... 84

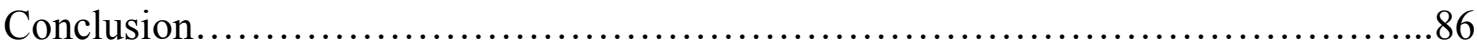

Catalogue A. Surviving votive offerings from female dedicators.....................89

Catalogue B. Temple inventory entries attesting votive offerings from female

Dedicators.............................................................. 97

Works Cited................................................................ 103 


\begin{abstract}
The mechanics of Athenian society in many ways empowered citizen women as essential components of their community. This reality, being at odds with Athens' pervasive patriarchal ideology, was obscured by men anxious to affirm the status quo, but also by women who sought to represent themselves as 'ideal' examples of their sex. Using the votive offerings dedicated by women to Athena on the Athenian Acropolis in the Archaic and Classical periods as a basis, this thesis explores such tensions between the implicit value of Athenian women, which prompted them to engage meaningfully with their wider community, and the ideological edict for their invisibility. This discussion is based primarily on two points: firstly, that the naming of a male family member in votive inscriptions denotes female citizen status, thus articulating citizen women's independent value and prestige within the polis; and secondly that the ubiquity of working women among the dedicators, and value of the offerings themselves, reveals women as controlling financial resources to a more significant extent than other sources would have us believe. In both cases, the actual value and authority of the female dedicators is concealed as the women aimed for a perception of conspicuous invisibility to legitimise their engagement with the public sphere.
\end{abstract}




\section{Acknowledgements}

First and greatest thanks go to my supervisor, Diana Burton, for her suggestions, support, and initial direction toward votive offerings as a potentially interesting topic. As always, she has been kind, generous in her time, and helpful in her comments. Thanks also to James Kierstead for his willingness to answer supplementary questions and recommend sources, to James Hugman for checking translations and to Michael Vermeulen for proofreading.

I am also grateful for having been funded in this project by the Victoria Master's by Thesis Scholarship.

Finally, thanks to my parents for their support. 


\section{Introduction}

The reality of ancient women's lives is difficult for modern scholars to glimpse. Ideologically, the model Athenian woman was domestic and publicly invisible, which deterred overt female engagement in the public sphere in any context other than those few otherwise sanctioned by their gender role. This desire to appear absent from public life means that authentic female experience is also all but invisible in our surviving sources. Indeed, where women are visible to us, it is typically at the hand of male artists and writers, resulting in a biased account that tells us more of how men thought women should be than how they actually were. In this difficult context, the present thesis aims to shed some light on the actual lived experience of ancient Athenian women by examining the votive offerings dedicated to Athena by female worshippers on the Athenian Acropolis in the late-Archaic and Classical periods. Votive offerings provide unique insight into the lives of women, as religion was the primary forum in which women could appropriately engage with the public sphere. The appropriately-feminine context of religion joined with the community-facing nature of dedications to allow women the rare opportunity to publicly express their personal identity. Although women never dedicated in numbers as high as men, ${ }^{1}$ this exception to the general rule of masked female identity is not only fruitful in affording us (relatively) unmediated contact with the women themselves, but also provides insight into the tensions underpinning Athenian gender ideology. Indeed, as their choices around dedication make clear, just as women were obliged to outwardly suppress the ways in which they engaged with the wider community, they too were undeniably valued members of the polis, whose independent wealth and status was something worth prompting. In the coming pages I hope to build a view of women's appearance in our sources as conspicuously invisible - that is, self-conscious of the need to appear disengaged from the public sphere - and that this active desire to mask public activity obscured the true extent of women's agency within their household and wider community.

The first chapter will lay the groundwork for my discussion. Firstly, it will place this thesis within its scholarly context, belonging at the end of a string of feminist works

\footnotetext{
${ }^{1}$ Just under ten per cent of all Greek votive offerings are attributed to women by Lazzarini (1976, $169 \mathrm{nn}$. 1-2, cited by Dillon 2002, 9).
} 
instigated by Sarah Pomeroy's foundational 1975 text. Then, it will provide a framework for my approach to some of the issues involved with the study of women in Athens namely the nebulous nature of status and 'respectability' - and the need to reconcile pervasive concepts of public and private with the more flexible reality of gendered behaviour. Finally, this chapter will introduce the evidence and explain my parameters. The second chapter will explore possible reasons for a change in naming patterns between the Archaic and Classical periods, as female dedicators began to regularly identify themselves in conjunction with a male family member. Here, I conclude that this shift reflects citizen women's desire to advertise their status as a result of the growing prestige attached to being an Athenian in the fifth and fourth centuries, as well as the increased emphasis on women's role within the polis at this time. Finally, my third chapter posits votive offerings as evidence for a higher degree of control over material resources than is traditionally ascribed to women. This is based on the position that women's engagement with property was pervasive, but hidden from public view through being conducted via domestic, customary, or 'off the books' channels that did not overtly challenge women's ideological exclusion from the public sphere. Ultimately, I conclude that, while women's lives were certainly limited by the legal and ideological pressures that excluded them from public life, this limitation was largely about appearance, with women in fact having value within their communities and behaving much more freely than male sources espousing ideology - or indeed, the women themselves - would like them to appear. 


\section{Chapter One: The context and evidence}

\subsection{Some issues with studying women in antiquity}

The study of women in antiquity has historically been hampered by the difficulty of interpreting available evidence. The most obvious hurdle is the lack of primary evidence from women in all media, but particularly in that traditionally prised by scholars: literature. Literacy levels were never high for Greek women, but female writers did exist, as attested by the much-studied works of Sappho. ${ }^{2}$ The public nature of her writing and her notoriety as a poet (which allowed her work to be preserved) was however an anomaly in the Archaic and Classical periods, with her still relatively modest body of public work the largest left by any female Greek author. ${ }^{3}$ This lack of female sources has historically been exacerbated by the tendency towards a targeted approach that limits available evidence further by focusing on a particular medium, as well as by an emphasis on upperclass women to the detriment of understanding the broad range of female experiences. ${ }^{4}$ Also impeding the study of women has been a willingness on the part of scholars, in the absence of female evidence, to accept the male view, steeped in ideology, as a reflection of reality. As no scholar can entirely escape the context in which he or she writes, such disinterest in working towards a more authentic version of the lived reality for women has historically reflected contemporary views. ${ }^{5}$ To give an example, the elision of the ancient and modern approaches to gender is evident in Arnold Gomme's troubling suggestion that the values of his day (early-twentieth-century England) might be used in a common-sense way to extrapolate Athenian gender ideology:

I consider it very doubtful if Greek theory and practice differed fundamentally from the average, say, prevailing in medieval and modern Europe. When Theognis said, "I hate a woman who gads about and neglects her home," I think he expressed a sentiment common to most people of all ages ... After all, a great deal of Greek literature deals with the relations between the sexes in one form or another; and it would have died long ago if Greek sentiments had been radically opposed to ours. ${ }^{6}$

\footnotetext{
${ }^{2}$ Literacy: Fantham et al. 1994, 106; Blundell 1995, 132.

${ }^{3}$ On women writers: Rayo 1991.

${ }^{4}$ Richter 1971, 1; Pomeroy 1975, xvi; Gould 1980, 39; Goff 2004, 13.

${ }^{5}$ Pomeroy 1975, 60.

${ }^{6}$ Gomme 1925, 25; criticised by Cohen $(1989,4)$.
} 
More earnest enquiries into the lives of women have become possible due to the advent of modern feminism. Feminist works that foregrounded authentic, subjective female experience, such as Pomeroy's ground-breaking Goddesses, Whores, Wives, and Slaves: Women in Classical Antiquity (1975), heralded a new interest in, and approach to, women in the Classics. Since Pomeroy, there has been a 'boom' of texts on women John Gould in 1980 even describes the subject of his article on women in Classical Athens as "positively trendy"; and it is items from this school that make up much of my bibliography. ${ }^{7}$ The contemporary approach to women attempts to avoid their historic mistreatment by directly engaging with the issues surrounding female evidence, and has the specific aim of accessing a reality for women that is obscured by a surface view of the patriarchal society that they inhabited. ${ }^{8}$ This includes a broad approach that maximises available evidence by including all types and media (sometimes, across vast time periods) $;{ }^{9}$ emphasis on the previously under-utilised fields of archaeology and religion where much of the surviving female evidence exists; ${ }^{10}$ and heightened consciousness of ideological biases present in some sources, and how this interacts with, but does not necessarily prescribe all aspects of reality. While in-depth engagement with methodology is not the purpose of this thesis, I will say that I find Barbara Goff's practical reconciliation of the structuralist and humanist approaches appealing, whereby she views women as complicit to the limitations under which they lived, having the agency to make choices regarding their behaviour, but doing so under the influence of social pressures that rewarded and punished adherences to and subversions of ideology respectively. ${ }^{11}$ Indeed, her suggestion that, "for Greek women, ritual practice is the primary arena in which are staged these various negotiations between 'ideology' and 'agency'” holds true for my purposes, as votive offerings were a forum in which both women's independent agency and their desire to appear to be adhering to ideology are at once manifested. ${ }^{12}$

\footnotetext{
${ }^{7}$ Gould 1980, 39. For example: Pomeroy 1975; Cohen 1989; Fantham et al. 1994; Blundell 1995; Dillon 2002; Goff 2004; Connelly 2007.

${ }^{8}$ This aim, and the contemporary value of recovering "alternative female 'truth'," is nicely laid out by Blundell $(1995,11)$.

${ }^{9}$ Self-consciously broad approach: Fantham et al. 1994, 7; Goff 2004, 22-23; James and Dillon 2012, 1.

${ }^{10}$ For example: Dillon 2002; Goff 2004; Connelly 2007; Kaltsas and Shapiro 2008.

${ }^{11}$ Goff 2004, 9-14.

12 Goff 2004, 14.
} 
While bearing in mind the dangers of directly applying contemporary values to an ancient context, this thesis firmly belongs to the feminist tradition - spearheaded by Pomeroy - that provides my secondary source material. But it aims to follow previous feminist scholars in: remaining objective (so far as is possible) by taking from the broader feminist social movement the aim of uncovering the reality of female experience while being conscious not to manipulate the evidence to find agency similar to that enjoyed by modern women where it did not exist; focusing on evidence directly from women, but being broadly open to supplementary media where relevant; and being alive to the interaction between reality and ideology.

\subsubsection{Status and 'respectability'}

Studies of women must begin from a position of recognising that 'women' is not a cohesive group, with individuals who fall under this umbrella experiencing life in vastly different ways according to status, wealth, and personal circumstances. But concurrently, as is evident in the context of votive offerings, while social factors (most notably for my purposes citizen status) shape women's social choices and identity in different ways, social status was a multifaceted spectrum rather than a series of categorisations, with the vast majority of women in Athens being to us indistinguishable from one another, despite technically belonging to different groups. In many cases, an Athenian citizen would present similarly to a metic woman; they dressed the same, often bore the same names, engaged in the same sort of activities, and were ultimately bound by the same gender ideals. ${ }^{13}$ Thus, although citizenship was ideologically significant, and a status that increasingly attracted social (and legal) scrutiny in the Classical period, other factors, such as genos, wealth, family circumstances and personality also contributed to a woman's behaviour.

Recent scholarship has begun to unpack the vast spectrum of female experiences that existed in ancient Athens, based on the matrix of social factors that contributed to a woman's status and acceptable behaviour. However, the concept of 'respectability' remains a pervasive, and somewhat problematic, means of distinguishing between upper

\footnotetext{
${ }^{13}$ Clothing: Kosmopoulou 2001, 305-6. Names: Kennedy 2014, 67; also see Chapter Two. Citizen and non-citizen workers: see Chapter Three. Gender as the defining status for both metic and citizen women: Kennedy 2014, 39.
} 
and lower class Athenian women, appearing even in texts that are otherwise alive to the complex nature of the female experience. ${ }^{14}$ For my purposes, the term 'respectable' is useful only in denoting a woman who is of a status that may (although did not necessarily) compel her to act in a way that adheres to the ideal for her gender, as much as was possible given her circumstances, in order to protect her reputation. This cannot denote any particular class, given that the desire to protect one's reputation, aside from being felt differently by each individual, may result from a complex tapestry of social factors. As shown by Rebecca Kennedy, metic women might seek to fulfil the feminine ideal as much as a citizen, and Against Euboulides (Dem. 57.30-36) shows us that even poor citizen women who engaged in disreputable behaviour (paid work) might have their citizen status and reputation defended through evidence of other citizen-like behaviour. ${ }^{15}$ Only the absolute elite - that is, the wealthiest of citizens from prestigious families - would almost certainly have had both the inclination to safeguard their prestigious position by protecting their reputation, as well as the means to conform to the social ideal. Similarly, only the lowest of women who engaged in the most socially stigmatised behaviours, such as prostitution, could be safely assumed to have had little ideologically sanctioned reputation left to protect. Between these two extremes would have existed the majority of women who may not have been able to conform to all aspects of the feminine ideal, but still had an interest in being viewed positively by their community. My use of the term 'respectable' does not aim to distinguish citizen from non-citizen or rich from poor, but rather to denote women who had an interest in adhering to social expectations in regard to gender ideology (which would comprise the majority of the population), as opposed those who had already violated proper feminine behaviour to the extent that they did not. Within this vast spectrum of 'respectable' women, I opt to use the phrases upper and lower class where generally varying levels of social prestige according to wealth, social position, and heritage must be acknowledged (although, given the nebulous nature of class, these terms are still not precise). ${ }^{16}$ It should also be noted here that, while I

\footnotetext{
${ }^{14}$ To name a few: Richter 1971, 5; Schaps 1977, 329; Gould's 1980, 45; Foxhall 1989, 33; Brock 1994, 339 n. 16; Kosmopoulou 2001, 289; Goff 2004, 61; Sommerstein 2009, 43; Levick 2012, 105; and Omitowoju 2016, 117.

${ }^{15}$ Kennedy 2014, 1-2 and 26 ff. On Dem. 57 see Chapter Two. Unless otherwise stated, all primary texts have been read in translation from the Loeb Classical Library.

${ }^{16}$ I chose upper class as opposed to terms such as elite or aristocratic since the latter are more restrictive and prescriptive; I find the more fluid term is more useful for the purposes of this essay.
} 
acknowledge the complex nature of class, in the absence of positive evidence for dedications from slaves, I have limited my sociological discussion to the lives of free women, given the strong distinction in Athenian thought between free and un-free.

\subsubsection{Public and private spheres}

Further complexity is added by the need to navigate Athenian concepts of public and private in a way that both acknowledges the deep ideological roots of this polarity, but also attempts to move past this in order to uncover the lived reality of women for whom it was, in practical terms, almost impossible to adhere to a strict public/private binary. The traditional understanding of Greek spaces as strictly separated into the masculine 'public' and the feminine 'private' has recently, and I think convincingly, been challenged. This is founded in part on recognition of a strict public/private opposition as reflecting Enlightenment ideals contemporary to the theory's development, rather than embodying the Greek context in which it was often difficult to define an act as wholly public or wholly private. ${ }^{17}$ The loosening of approaches to public and private has also been facilitated by a trend away from strict interpretive adherence to ideology as inherited via male sources, and toward pursuit of a more likely reality in which men sometimes appropriately existed within the oikos and women sometimes appropriately left the house and engaged directly with the polis. ${ }^{18}$ A more functional understanding of women's engagement with the public sphere is particularly necessary in studies of women's religion, where public female agency is at its most visible; indeed, women's participation in dedication was just one of many religious activities that prompted Athenian women of all classes to leave the oikos and be seen by the wider community.

To be clear, an individual would usually be understood as aligned with the 'private' sphere if he or she were primarily occupied by non-commercial household tasks that were in the interest of the immediate family group only, and interacted almost exclusively with the members of his or her own, or adjacent, households. Conversely, an individual would be aligned with the 'public' sphere if he or she took part in the formal mechanisms of the community that function in the interests of the wider group as a whole

\footnotetext{
${ }^{17}$ On the Enlightenment origins: Katz 1992, 80 ff.; Wagner-Hasel 2003, 243-5; Evans 2004, 8-9. One example of deme religion as at once public and private: Humphreys 2004, 130-1.

${ }^{18}$ Reliance on ideology criticised by: Cohen 1989, 4; Nevett 2011, 590.
} 
(legally, politically, and militarily), and routinely engaged socially with community members beyond his or her immediate friends and family. Each sphere is associated with particular physical areas - the private sphere with the enclosed, family-oriented space of the oikos where domestic labour took place, and the public sphere with the (often openair) spaces in which the non-kin members of the community might encounter one another (such as the agora), and, even more acutely, the spaces where the formal social mechanisms of the community were administered (such as the Pnyx and Areopagos). Such concepts of public and private cannot be abandoned entirely, as there remains an undeniable equivalence of the private, domestic sphere with women, and the public, communal sphere with men in Athenian thought. This can be seen in the women depicted undertaking the quintessentially feminine domestic task of wool working on a lekythos of the Amasis Painter; ${ }^{19}$ in the women who sit rooted in klismoi on red-figure vases - a sash or mirror on the wall, or loom in the background, to denote the scene as recognisably interior and domestic - while their husbands stand at the door, dressed for the outside world, ${ }^{20}$ in Penelope's virtuous commitment to domestic labour in the Odyssey or Andromache's exemplary willingness to remain inside the house in Euripides' Trojan Women (644-56); and even in the relative colours of male and female flesh in vasepainting, with white reflecting women's time spent indoors, while brown recalls the hours men spent exposed to the elements. ${ }^{21}$ Men who stayed indoors were considered effeminate, ${ }^{22}$ while women who moved freely in the exterior world were seen as sexually permissive. ${ }^{23}$ Besides the exterior world being a place where prostitutes could openly move about, the interior is strongly associated with female chastity. ${ }^{24}$

\footnotetext{
${ }^{19}$ Attic black-figure lekythos by the Amasis Painter showing wool working, c. 540 BC. New York, Metropolitan Museum: 31.11.10. BAPD 310485. Image: Lefkowitz and Fant 1982, fig. 9; also see fig. 3 for another wool-working scene.

${ }^{20}$ Such as the Attic red-figure hydria showing a seated wife working wool before her standing husband, c. 440 BC. London, British Museum: E215. BAPD 214529. Image: Beard 1991, fig. 4. See: Reeder 1990, 123-297 and Beard 1991, 12-26.

${ }^{21}$ On the male and female body (including variation in skin colour) as a means of mapping space: Davidson 2011, 609.

22 Such as the unmanly Aigisthos whose negative characterisation in the Oresteia is heightened by spending time indoors with Clytemnestra (Aes. Ag. 1625-6, cited by Davidson 2011, 600); also Xen. Oec. 7.30.

${ }^{23}$ Cohen 1989, 6.

${ }^{24}$ Davidson $(2011,602-3)$ uses the concept of moicheia to demonstrate that for women sexual violation was ideologically linked to penetration of the physical houses they occupied.
} 
However, even on an ideological level, men were not strictly excluded from the oikos, nor women from the exterior world; some domestic tasks were considered the domain of men, and some public tasks that of women. It was men who took up the most senior position within the household, often acting on behalf of the oikos. ${ }^{25}$ For instance, dedication to Zeus Herkeios, although concerning the oikos and thus pertaining to the private, domestic sphere, was carried out by the kyrios and inherently masculine in nature. Indeed, this act performed by the kyrios on behalf of his household was so socially significant that candidates for the archonships would be asked to confirm that their house contained a shrine to Zeus Herkeios (and Apollo Patroos) ([Aristotle] Athenaion Politeia 55.3). ${ }^{26}$ Further, it is just one example of men's natural role within the oikos, with another found in the Amphidromia, during which the father exercised authority even in the overtly feminine context of child-rearing by formally accepting a child into his oikos. Men not only acted on behalf of and within the oikos through the tasks ideologically prescribed to their gender, but also comfortably existed within its physical limits. Beate Wagner-Hasel interprets Xenophon's Oeconomicus as showing that the oikos is the domain of both men and women, with masculine and feminine objects named as existing together under its roof. ${ }^{27}$ Indeed, the symposium - participation in which was an essential marker of the male citizen - took place within the house in the andron. In the same vein, women could exist comfortably in the public sphere. Some instances were motivated by necessity, such as the practical need for less wealthy women to leave the house and personally collect water from a spring or fountain, or supplement household income by working outside the home. ${ }^{28}$ Most significantly, religion provided a platform from which women could not only enter the public sphere, but also have significant authority within it. ${ }^{29}$ Priestesses were genuine public figures whose influence could be profound. For example, Herodotus tells us of one priestess of Athena Polias who directly confronted the Spartan King Kleomenes (Hdt. 5.72), and another who influenced the community's decision to flee Athens during the Persian invasion (Hdt. 8.41). ${ }^{30}$ Only very few women were able to fill

\footnotetext{
${ }^{25}$ Male dominated oikos: Sourvinou-Inwood 1995. Cf. Foxhall $(1989,23)$ who views men and women as a cohesive social unit within oikos, but "separate, opposing and unequal" outside of it.

${ }^{26}$ Garland 1992, 13. Also on masculine nature of dedication to Zeus Herkeios: Avramidou 2015, 8-9.

${ }^{27}$ Wagner-Hasel 2003, 248-9.

${ }^{28}$ Cohen 1989, 7-9. For more on working women see Chapter Three.

${ }^{29}$ Sourvinou-Inwood 1995, 112.

${ }^{30}$ Discussed by Connelly 2007, 61 .
} 
these prestigious religious roles, with old priesthoods reserved for women from elite families - the priestess of Athena Polias, for instance, was drawn from the Eteoboutadai. ${ }^{31}$ But even the average citizen woman found public significance through religion, with female festivals such as the Thesmophoria being vital to the wellbeing of the community as a whole. ${ }^{32}$ Yet, similarly to men's natural position as leaders of the oikos being sanctioned by, rather than a subversion of, ideology, women's engagement in public religion as priestesses and festival-goers was not a violation of ideal behaviour made tolerable by practical need, but rather an engrained, socially sanctioned component of women's gendered role. Indeed, religion as a natural component of women's gender role can be seen in an often-cited fragment of Euripides' Melanippe Captive (frag. 494 K), where Melanippe states that: "in matters concerning the gods, for I consider these matters to be the most important, we [women] have the greatest share."33

Thus, it is not right to say that the private sphere was strictly ideologically feminine, while the public was strictly masculine. Rather, each sphere was subdivided into masculine and feminine areas and tasks. A man could engage with the oikos in a way appropriate to his gender by sacrificing on behalf of the family or dining with his peers within the house, while a woman could leave the oikos to perform tasks in support of her household, and even engage with the welfare of the polis through religious activity. The major division was not between public and private, but between masculine and feminine, with the two sets being loosely, but not absolutely, aligned. This reflects David Cohen's widely accepted approach of viewing the general separation of gender spheres - rather than the strict association of women with the private sphere (specifically, their physical seclusion within the house) and men with the public - as more accurately reflecting Athenian attitudes and lived reality for women. ${ }^{34}$ In this reading, women may sometimes exist in public without damage to their reputations, and men sometimes in private, so long as each gender adheres to their broader ideological role. The primacy of the gender binary in Athenian thought, and its association with, but not equivalence to, the public and

\footnotetext{
${ }^{31}$ Connelly 2007, 44-45.

${ }^{32}$ See Chapter Two.

33 Trans. Dillon 2002, 1.

${ }^{34}$ Cohen 1989, passim.
} 
private is laid out by Lin Foxhall, who describes gender as "probably the most vigorous expression of meaning available to ancient Greek culture." 35

Thus, in order to reconcile women's routine engagement with activities outside the oikos with the general view of them as most appropriately existing in a domestic context, a series of legitimising and mitigating factors based on other elements of the female gender role were utilised. ${ }^{36}$ The need for a legitimate motivation to leave the house is shown by Cohen, using the example of the husbands who in Aristophanes' Ecclesiazusae (520, 1008) and Thesmophoriazusae (414, 519, 783 ff.) are displeased to discover their wives are not at home: "The husbands know that they [their wives] go out, but they should not be found to have been out, particularly not at an inappropriate time or without a legitimate purpose..." ${ }^{37}$ In order to legitimise a woman's public activities, she should ideally be motivated by some other part of her ideologically prescribed gender role. The extensive public agency and notoriety of priestesses, for example, was legitimised by the context of religion, which sat within the natural role prescribed to women; hence it was this context that legitimised female dedicators leaving the house in order to deposit votive offerings. Domestic tasks on behalf of the household, such as fetching water, also appropriately brought many women outside of the house. ${ }^{38}$ Even activities stigmatised for women, such as paid work outside the home, were made more legitimate by female professions generally being founded on domestic tasks associated with women's natural role. ${ }^{39}$ Further, even if a woman acted for a legitimate purpose or in a feminine way, her physical existence in the public sphere still needed to be softened by various mitigating factors. Lloyd Llewellyn-Jones has suggested that the widespread veiling of women in public by pulling exterior clothing over the head and face did just this, as did the possible chaperoning of citizen women. ${ }^{40}$ Indeed, we can even see mitigating behaviour in female dedicatory patterns on the Acropolis.

This thesis will continue to draw on concepts of public and private, and to use these terms, as there is an evident need to acknowledge this opposition as it existed in

\footnotetext{
${ }^{35}$ Foxhall 1989, 23.

${ }^{36}$ Cohen 1989,11 .

${ }^{37}$ Cohen 1989, 12

${ }^{38}$ Cohen 1989, 7.

${ }^{39}$ See Chapter Three.

${ }^{40}$ Veiling: Llewellyn-Jones 2007, 256. Chaperoning: Nevett 2011, 589.
} 
Athenian ideology. The terms also provide a framework to describe how and where Athenian men and women would have been imagined to exist most naturally, where they did not need legitimising or mitigating behaviour in order to maintain propriety. ${ }^{41}$ However, in doing so, I recognise the following: that Athenian concepts of public and private do not align exactly with our modern understanding of the terms; that 'public' is not strictly synonymous with 'masculine', nor 'private' with 'feminine'; and that the boundary between public and private could be readily crossed so long as overarching gender ideals were adhered to. ${ }^{42}$

\subsection{The nature of votive offerings}

Greek religion was based on a perpetual cycle of giving and receiving between gods and mortals in an interdependent relationship called charis. ${ }^{43}$ The gods provided the basic conditions for life - the changing of the seasons, germination of crops, knowledge of craft, and so on - as well as granting occasional instances of personal favour, such as facilitating a successful commercial enterprise or delivering an individual from danger. In return, humans gave the gods gifts, either in the form of sacrifice or votive offerings. ${ }^{44}$ These votive offerings were exceptionally diverse in nature. They could be retrospective, giving thanks for favour already granted, or prospective, looking hopefully forward to future prosperity. They could be deposited privately by an individual or small kin group, or communally by a polis. A broad range of circumstances could prompt an offering, with an individual or group generally dedicating whenever they felt necessary. ${ }^{45}$ The type of object deposited was likewise variable - practically anything could serve as a gift for the gods, with offerings ranging from ostentatious artworks commissioned for the purpose, to everyday objects such as clothing, work tools or human hair. ${ }^{46}$ The god to whom a particular offering should be directed also seldom followed set rules. A dedicator may in some instances select a deity whose sphere of influence was particularly relevant to their

\footnotetext{
${ }^{41}$ We should bear in mind that not all women sought to maintain propriety, with the severity of pressure to adhere to ideology varying according to the status and circumstances of each woman.

${ }^{42}$ Even boundaries regarding gendered tasks and spaces were not totally impermeable. See: Nevett 2011, 589-90 and Avramidou 2015, 8-9.

${ }^{43}$ Jim 2014, 66-68.

${ }^{44}$ Parker (in Boardman et al. 2004, 270) describes choruses as the third major component of Greek religion, although prayer was not a 'gift' in the same way sacrifice and dedication were.

${ }^{45}$ For a concise, comprehensive list of reasons for dedication see ThesCRA (Boardman et al. 2004, 278280) or van Straten 1981, $88 \mathrm{ff}$.

${ }^{46}$ For breadth of objects dedicated see ThesCRA (Boardman et al. 2004, 293 ff.).
} 
reason for deposition. For example, Asklepios commonly received offerings related to recovery from illness, while Athena attracted offerings from craftspeople. ${ }^{47}$ Or, specific gods or goddesses may receive particular objects in the course of ritual attached to certain life events, such as Athenian girls upon marriage ritually dedicating their toys to Artemis, who would then also receive their clothes after childbirth. ${ }^{48}$ Often, however, a dedicator did not need to select the divine recipient based on their area of influence, with the majority of worshippers dedicating locally out of convenience. ${ }^{49}$ The type of person who could dedicate was likewise broad, with (for the Acropolis at least) a diverse mix of ethnicities, classes and genders being represented (notwithstanding the fact that the Acropolis was primarily a local sanctuary used by those living in Attica). ${ }^{50}$ The poor were not excluded from dedication, with the vast majority of deposits made from cheap materials such as wood or repurposed pottery - an old roof-tile in one instance being transformed into an offering. ${ }^{51}$ Indeed, we must remember that the often opulent offerings that survive in fact represent only a small portion of the dedications originally deposited, the majority of which were inexpensive and made from perishable material; thus what evidence we have is skewed falsely towards elite dedicators.

Once the recipient had been selected and the object deposited, votive offerings, unlike sacrifices, were (semi-)permanent fixtures of the physical environment of the sanctuary. The object, as the property of the god, was customarily inalienable once dedicated. While practical necessity sometimes required the movement or transformation of offerings to maintain the functionality of a site, precautions were taken to preserve the original spirit of the dedication. Older inexpensive items, when cleared away to make room for new offerings, were typically deposited in pits within the temenos boundary, and where metal dedications were melted down, the original details (dedicator and item deposited) were preserved via inscriptions. ${ }^{52}$ Such mitigating behaviour, though primarily motivated by a desire not to deprive the god of their property, also reveals the relationship

\footnotetext{
${ }^{47}$ Offerings to Asklepios see Aleshire 1989, passim; also the catalogue of anatomical votives, van Straten (1981, 105-151). Craftsmen dedicating to Athena as patron: Keesling 2003, 75.

48 Toys: Anth. Pal. 6.280, cited by Dillon 2002, 215. Clothing evident in inventory lists at Brauron, $I G \mathrm{II}^{2}$ 1514 , cited by Goff 2004, 29.

${ }^{49}$ Boardman et al. 2004, 317.

${ }^{50}$ For a comprehensive view of dedicators see catalogue in Raubitschek 1949.

${ }^{51}$ Wooden pinakes: Wagner 2001, 96-97. Repurposed tile: Jim 2014, 159.

52 van Straten 1981, 80; Boardman et al. 2004, 280-1. Inscriptions: IG II/III ${ }^{2}$ 839-840; IG VII 303.
} 
that dedications had with the wider community who were witnesses of the dedicator's wealth and piety. As put by François De Polignac:

Offerings to the gods are at the heart of a triangular relation: between dedicator and deity, whether the former is asking for or reciprocating a favour; between dedicator and community, since the offering said something about his identity, status and role in this community; and also between god and community, when the latter could recognize in the wealth and fame of its sanctuary a sign of its close relation with the deity. ${ }^{53}$

Thus, a person whose offering was melted down might feel deprived of the social prestige afforded by an impressive dedication if the inscription did not maintain the community's capacity to appreciate the value of the original offering. ${ }^{54}$ Indeed, dedicators were conscious of their offerings' visibility within the community and utilised this platform to assert their personal identity. De Polignac goes so far as to phrase this self-identification in terms of competition (the agon) as fundamental to Greek culture - prestigious votive offerings aimed not just to impress one's peers, but to outdo them. ${ }^{55}$ People dedicating in the open air would vie to place their offerings as close to the prestigious or frequented areas of the sanctuary as possible (particularly the temple or major thoroughfares), to the extent that such jostling - when combined with the massive volume of items being deposited - in some instances required intervention by sanctuary officials. ${ }^{56}$ Further, those who had the means to do so used the sanctuary as a forum in which to display the extent of their resources, as can be seen in the large commissioned marble monuments and objects made from precious metals attested on the Acropolis. ${ }^{57}$ In addition to the splendour of the offering itself, a dedicator might add self-affirming information to the inscription, naming a prestigious family member or the famous artist responsible for the piece, or noting that it was deposited in celebration of serving an honorific office. ${ }^{58}$ Further, overt self-praise was not beyond the scope of votive offerings, as can be seen in an offering dedicated by Melinna, who lauds her own abilities as an artisan and

\footnotetext{
${ }^{53}$ De Polignac 2009, 441.

54 The moral obligation to preserve the original dedication details - for the god the god and the dedicator

- is explicit in Dem. 24, 180-2.

${ }^{55}$ De Polignac 2009, 439-442.

${ }^{56}$ An inscription from the Asklepieion at Rhodes establishes an offering-free zone at the lower part of the sanctuary, and prohibits deposition of any object that would "prevent people walking past;" another from Melitus asks dedicators not to attach offerings to the woodwork of "the new stoa" (LSS 107 and 123; cited by van Straten 2001, 213-14).

${ }^{57}$ See catalogues: the majority of items included are expensive.

${ }^{58}$ Family member: Cat. B5. Artist: Cats. A4 and A28. Honorific office: Cats. B23 and B25.
} 
businesswoman. ${ }^{59}$ Despite the discomfort that these dual purposes of piety and self-praise arouse in modern sensibilities, which prize the separation of sacred and secular, this duality was natural and unproblematic for the Athenians, who "constantly and without embarrassment" used votive offering to advertise their own achievements. ${ }^{60}$ Indeed, it is votive offerings' position at the junction between sacred object and secular affirmation of personal identity that makes them valuable as evidence for Athenian social history, particularly for women who were otherwise all but invisible in public life.

\subsection{The evidence}

The evidence for this thesis is comprised of two main types. The first are the surviving offerings dedicated in the open air on the Acropolis, complied in Catalogue A. Many of these have been lifted from Antony Raubitschek's catalogue of monumental stone offerings from the Athenian Acropolis. ${ }^{61}$ In addition to Raubitschek, ThesCRA and books on women in religion have been somewhat fruitful in turning up more recent or nonmonumental offerings, but these sources are ultimately incomplete given that neither set out to provide an exhaustive catalogue of female offerings. ${ }^{62}$ The surveys of votive offerings from all over Greece by William Rouse and Folkert van Straten also supplement my corpus, but only in a limited way given the small portion of words that each devotes to Athens, and even smaller portion to offerings from women. ${ }^{63}$ Amalia Avramidou's article on family-oriented dedications provides an impressively comprehensive catalogue of named female dedicators, although even this is not totally complete. ${ }^{64}$ Accordingly, my method for amassing this type of evidence has unfortunately but necessarily been somewhat ad hoc, simply adding items as I came across them.

The second type of evidence is the inventories that list precious items, now lost, that were held inside Athena's temples on the Acropolis, complied in Catalogue B. These inventory lists have been comprehensively redacted and set out in Diane Harris'

\footnotetext{
${ }^{59}$ Cat. A31.

${ }^{60}$ Boardman et al. 2004, 270.

${ }^{61}$ Raubitschek 1949.

62 Boardman et al. 2004, 281-318. Women and religion: Dillon 2002; Kaltsas and Shapiro 2008, 31-76. Also Jim 2014.

${ }^{63}$ Rouse 1902; van Straten 1981, 65-151.

${ }^{64}$ Avramidou 2015, Table One. I have excluded items from Avramidou that compromise the agency of the female dedicator by the object being deposited by another on her behalf (Cats. 23 and 25), and also for being dedicated to a god other than Athena (Cat. 14).
} 
monograph. ${ }^{65}$ In total, I have collected thirty-eight examples of surviving items dedicated by women, and lifted from Harris' catalogue twenty-five female offerings recorded in the temple inventories. A third female dedicator is also named in the inventories, but details of the objects deposited are lost. ${ }^{66}$ Accordingly, I have excluded this entry from my catalogue - as Harris also does, not assigning Sostrate a catalogue number and only identifying her in the list of dedicants near the end of her monograph. ${ }^{67}$

For an item to be included in my catalogue, there must be firm evidence that the dedicator was female. The firmest indication is provided by a votive inscription that includes a complete female name, or the latter section of a name with a feminine ending, and this is the test that affirms that female status for most of the items in my catalogue. There are two instances where the dedicator's personal name could be either male or female: Kapanis and Kalis. ${ }^{68}$ I have, however, opted to include these, along with a third dedication where the name may be reconstructed as either male or female (Philea or Phileas), with the caveat that these items are uncertain. ${ }^{69}$ Instances where a woman's personal name is not provided, but the dedicator is referred to as the gyne of a named male, are also obviously female and so included in this thesis. ${ }^{70} \mathrm{I}$ have found no criteria besides a female name or label of gyne to be a satisfactory indicator of gender due to the difficulty of interpreting other features of votive offerings. Representation of a woman on the offering itself, for instance, is not enough to indicate a female dedicator. This is demonstrated by Archaic korai, which are possibly the most studied type of female representation on the Acropolis. Although this category of statue always took the form of a maiden, they were regularly dedicated on the Acropolis by men (in fact, only male dedicators have thus far been identified where the gender is discernible), so, in these instances, the female figure could not have reflected the identity of the dedicant. ${ }^{71}$ The type of item dedicated on the Acropolis is also not enough to infer a dedicator's gender, as even items associated with women and given by them in high numbers, such as silver

\footnotetext{
${ }^{65}$ Harris 1995. Note: Harris later publishes under the name Harris-Cline.

${ }^{66}$ Sostrate: $I G I^{2} 1419$, line 5.

${ }^{67}$ Harris 1995, 225.

${ }^{68}$ Cats. A10 and A12.

${ }^{69}$ Cat. A9.

${ }^{70}$ Cats. A29-30 and B15.

${ }^{71}$ Keesling 2003, 115-118 and 97 ff. See also Raubitschek 1949, 465; Dillon 2002, 12.
} 
phialai, were also dedicated regularly by men. ${ }^{72}$ Traditionally feminine objects, such as belts, mirrors and clothing, have been associated with woman dedicators due to their gendered use in secular contexts. ${ }^{73}$ The exclusive association of feminine personal items with women, while it is common-sense, is still speculative (except in situations where a female dedicator is supported by ritual contexts evidenced in other media, such as clothing at Brauron). ${ }^{74}$ For this reason, and to limit the scope of this thesis, these items have been excluded from my study unless a female dedicator is named. ${ }^{75}$ Because the vast majority of dedications do not include an inscription at all, the need for a female name or title of gyne to determine gender means that there were a great many more dedications made by women that we have no way of identifying. But this limitation is, unfortunately, unavoidable.

The need for a female name also limits the type of object that is included in my survey. Vast numbers of terracotta plates and pinakes were dedicated on the Acropolis. ${ }^{76}$ Where these did include an inscription (which was not often), the text generally followed pottery conventions (descriptive labels, kalos inscriptions, and so on) rather than the formulae that are typically found in votive inscriptions where the item is identified as a votive and the dedicator named, possibly along with other information (such as details identifying the worshipper or the reason for dedicating) ${ }^{77}$ It has been argued that women (and other poor, socially marginal groups) made up a large number of the dedicators depositing this type of offering because it was the more affordable alternative to expensive marble or metal items. ${ }^{78}$ However this hypothesis is based on a lack of access to resources for women, a point on which I do not agree, ${ }^{79}$ as well as the assumption that inexpensive offerings were only dedicated by the poor, while the rich always dedicated grand offerings that were as expensive as they could afford - something that Kyriaki

\footnotetext{
${ }^{72}$ Men and women dedicating the same types of objects: Raubitschek 1949, 465-6; Ridgway 1987, 402; Karoglou 2001, 52. Phialai associated with women: Dillon 2002, 18. Freedmen (and possibly male metics) as dedicators of silver phialai: Hurwit 1999, 60; Harris 1995, 114; Meyer 2010, passim.

${ }^{73}$ Dillon 2002, 13; Ridgway 1987, 402.

${ }^{74}$ Ridgway $(1987,402)$ says “objects of personal adornment...must have been made primarily for women, and were dedicated by them in numbers" simply because of the objects' feminine connotations.

${ }^{75}$ My catalogue includes only one mirror dedicated by a named woman (Cat. A23).

${ }^{76}$ Wagner 2001, 95-104; Karoglou 2010, passim.

${ }^{77}$ Karoglou 2010, 40-3. On votive formulae see ThesCRA (Boardman et al. 2004, 274-78).

${ }^{78}$ Kron 1996, 159.

${ }^{79}$ See Chapter Three.
} 
Karoglou and Catherine Keesling argue was not true. ${ }^{80}$ Indeed, as is generally the case for all types of offerings, there is no discernible distinction along gender lines for pinakes. ${ }^{81}$

Again partly for the sake of scope, I have opted to exclude votive reliefs, despite this being a medium in which the women depicted are more likely to represent the dedicators. ${ }^{82}$ However, votive reliefs, where they do depict female dedicators, tend to represent them within family groups, and not always in a position that suggests the women have agency over the offerings; that is, the group is most often led by a man, presumably the leader of the household. ${ }^{83}$ Such family-oriented items, which are not clearly dedicated primarily by the woman, do not aid the purpose of this thesis. My catalogue does include two instances where a female dedicator mentions children - in one case depositing on their behalf, and in the other identifying them as benefiting from her successful career as well as four instances where multiple women dedicate together. ${ }^{84}$ In these cases, however, the votive inscription makes clear that it is this woman (or women) who has agency over the offering by naming her as the dedicator.

Where a female dedicator is identifiable in an inscription, I assume that the offering was commissioned to her specifications and dedicated by her personally, rather than commissioned or deposited by a man on her behalf as has sometimes been suggested. ${ }^{85}$ There is no reason to believe that female dedicators could not have exercised control over the dedication process. This is supported by scholarship's recent rejection of the traditional view that women were strictly secluded within the oikos, as well as evidence for women having access to property and so having the means to independently dedicate. ${ }^{86}$ More importantly, the common practice of explicitly stating when a dedication was made on behalf of another person speaks against any temptation to read male agency into offerings that do not overtly identify a surrogate dedicator; indeed, we can even point

\footnotetext{
${ }^{80}$ Karglou 2010, 49-50; Keesling 1995, 395.

${ }^{81}$ Karoglou 2010, 50-54.

82 van Straten 2000, 216.

${ }^{83}$ See Dillon (2002, 31-3) for discussion of an example from the Acropolis where the adult woman is placed at the back of the group (Athens, Acropolis Museum: 581).

${ }^{84}$ Mention children: Cats. A28 and A31. Joint female dedicators: Cats. A17, A24, A27, and B5.

${ }^{85}$ Harris-Cline $(2003,6)$ argues that items other than those that were already the personal property of the woman could be dedicated "only with her husband or father's express permission."

${ }^{86}$ Seclusion as unrealistic for most women: Cohen 1989, passim; Brock 1994, 346; also see Chapter One. For discussion of women's property see Chapter Three.
} 
to specific gendered examples of votive inscriptions that expressly acknowledge a male dedicator has deposited on behalf of a woman. ${ }^{87}$

The earliest item in Catalogue A dates to c. $550 \mathrm{BC}$, and the latest to just after the end of the Classical period. I have opted to exclude the plentiful Hellenistic examples of female dedications in order to maintain a level of social cohesion throughout my research - that is, avoiding the vast change in context between Archaic and Classical poleis and Hellenistic kingships. Similarly, I have limited evidence to dedications from the Athenian Acropolis in order to avoid disparities between the gender values of different poleis, and to offerings made to Athena to avoid difference between cults. As a result of this, I have excluded two inventory entries that Harris identifies as naming offerings from women because the inscription states that they were dedicated to Artemis, not Athena. ${ }^{88}$ I hope that limiting the scope of this project will result in a more focused view of Athenian women's lives.

With these parameters having been set, the type of surviving offerings that appear most often in Catalogue A are large monuments - namely marble basins or statues placed on stone pillars, columns or low bases - and small bronze vessels, often in shapes associated with ritual. In addition to these are some unique objects that remind us of the breadth of items that could be deposited, including a miniature bronze shield bearing a gorgon head dedicated by Phrygia (cover image) ${ }^{89}$ On the other hand, the inventory items compiled in Catalogue B are generally small, valuable objects, such as jewellery, vessels made from precious metals, precious stones, ivory items, and even pieces of gold.

The majority of the physical remains within my time period are clustered around the late-sixth and early-fifth centuries (see Catalogue A). Twenty-eight items date between 550-480 BC (inclusive), while only ten date from after $480 \mathrm{BC}$ to shortly after $350 \mathrm{BC}$. Yet further, only two of these later ten date after $420 \mathrm{BC}$. It has been suggested by Raubitschek that this clustering was a result of the opening up of the Acropolis to traditionally non-elite people - particularly craftspeople - which occurred after the fall of

\footnotetext{
${ }^{87}$ E.g.: DAA $79\left(I G \mathrm{I}^{3} 745\right)$, where a father dedicates in fulfilment of his daughter's vow.

88 V.138 and V.151.

${ }^{89}$ Phrygia: Cat. A8. Other stand-alone objects include: a black-figure plate (Cat. A1), bronze cymbal (Cat. A20), bronze mirror handle (Cat. A23), small decorated base (Cat. A24), and bronze statue of Athena (Cat. A26).
} 
the Peisistratids who monopolised this space by using it as a private residence. ${ }^{90}$ However, it is not certain that the Peisistratids did live on the Acropolis, and Keesling and Theodora Jim suggest that Raubitschek overstates craftspeople's presence in the offerings of this time. ${ }^{91}$ Chronological and ideological inconsistencies also make correlation between the advent of democracy and increased dedication dubious; indeed, the 'boom' in votive offerings began before the advent of democracy, and continued long after its initial conception. ${ }^{92}$ This increase of offerings was more likely the realisation of a slow increase in emphasis on the Acropolis as the major religious site in Athens over the course of the sixth century. ${ }^{93}$ Ultimately, the abundance of late-Archaic offering may be purely an archaeological coincidence; it was those items deposited just before, or soon after, the Persian destruction of the Acropolis in $480 \mathrm{BC}$ that were preserved in the foundations of subsequent buildings and thus have been inherited by modern scholars. ${ }^{94}$ Finally, as will be discussed in Chapter Two, developing pressures on women to adhere to gender ideology may have contributed to the decrease in female offerings deposited in the open air, as offerings from men continued when women's disappeared. ${ }^{95}$

Indeed, physical remains from female dedications drop off around the mid-fifth century, leaving a void until they again appear in surviving temple inventories. Women are attested in the inventories between 406 and $307 \mathrm{BC} .{ }^{96}$ But, the nature of the inventories, in that the same offerings were recorded year after year, means that the first surviving entry for a certain item may not represent the year that it was initially dedicated. This is made clear by two instances where the inscription indicates an early date of dedication. ${ }^{97}$ For this reason, I have chosen to include all inventory entries that name a

\footnotetext{
${ }^{90}$ Raubitschek 1949, 465; also: Hurwitt 1999, 126-129.

${ }^{91}$ Against Acropolis as Peisistratid residence: Hurwitt 1999, 118; Keesling 2003, 40. Raubitschek overstating craftspeople: Keesling 2003, 71-74 and Jim 2014, 137 and 168.

${ }^{92}$ Keesling 2003, 36-62.

${ }^{93}$ Laid out by Hurwitt (1999, 67-137).

${ }^{94}$ Keesling (2003, 49-50) argues that a terminus ante quem of $480 \mathrm{BC}$ for does not hold up for most of the Perserchutt deposits on the Acropolis, indicating that there was an the interval of some years between destruction and deposition of remains, as well as the possibility that items were selectively destroyed rather than universally razed. Also: Ridgway 1987, 401.

${ }^{95}$ Men's offerings continuing: Dillon 2002, 17. For a comprehensive overview of monumental offerings from men (and women) on the Acropolis, see: Raubitschek 1949 and Keesling 2003.

96 There are no attested Archaic inventories of dedications in Greece, although they may have existed on perishable material or as memorised hexameter catalogues (de Polignac 2009, 441-2).

${ }^{97}$ Cats. B21 and B23.
} 
female dedicator, even those which first appear in the early Hellenistic period, and thus technically fall outside of my time-frame (though never by more than two decades). ${ }^{98}$

Due to the limitation of relying on a relatively small corpus of published pieces from an incomprehensive variety of sources - as well as the structural restrictions that I have imposed for the sake of scope and consistency - I have opted against extensive statistical analysis, as a few overlooked items in a sample size this small could skew interpretation quite significantly. Rather, my argument for the extensive, though veiled, agency of Athenian women will be supported by three major trends: firstly, that women move from identifying themselves by their personal name alone to additionally including the name of a male family member; secondly that women move from dedicating items in the open air to almost exclusively dedicating within the temples of Athena; and thirdly, that a substantial number of the physical remains (almost half) identify themselves as a tithe or first-offering. I feel comfortable making these observations from my, I'm sure incomplete, dataset as these trends are obvious and overarching, and, in the first two instances, have also been identified by previous scholars. ${ }^{99}$

\footnotetext{
${ }^{98}$ The exception to this is a gold rhyton dedicated by Alexander's wife, Roxane, as this was very likely dedicated after 323 BC (Dillon 2002, 18-9).

${ }_{99}$ Andronymic: Raubitschek 1949, 465; Harris 1995, 237; Dillon 2002, 17-8; Keesling 2003, 75-77.

Temple offerings: Keesling 2003, 77.
} 


\section{Chapter Two: The andronymic as a statement of female citizenship}

\subsection{Naming Athenian women}

The avoidance of disseminating 'respectable' Athenian women's names in public has traditionally been emphasised in studies of women. ${ }^{100}$ Indeed, suppression of independent female identity can be seen in overt affirmations of ideology, such as Perikles' Funerary Oration - which urges woman to avoid being spoken of in public, either positively or negatively (Thucydides 2.45.2) ${ }^{101}$ - as well as the tendency for citizen men to avoid mentioning 'respectable' women by name in formal public contexts, such as legal speeches or even staged comedy. ${ }^{102}$ But, most obviously, it is demonstrated by the lack of named female individuals who survive in the historic record, with the names of eminent women eluding even ancient historians. ${ }^{103}$ It is striking that in votive inscriptions where a female dedicator identifies herself, she almost universally provides her personal name. The only other acceptable context for publicly naming 'respectable' women was funerary monuments, with taboos surrounding public identification of women relaxing after the individual's death, so allowing her name to be displayed in the cemetery. ${ }^{104}$ This makes votive offerings exceptional in their capacity to display and preserve women's personal names in the public sphere, as they were the only vehicle through which a woman who was (presumably) living at the time of deposition could permanently publicise her name. $^{105}$

\footnotetext{
${ }^{100}$ Per Chapter One, it should be noted with caution that ideas of respectability have traditionally underpinned discussions of naming women: see Gould's 1980, 45; Schaps 1977, 329; Sommerstein 2009, 43. I retain the phrasing here to preserve the understanding of name suppression as aligning women with the ideal of invisibility (and thus being concerned with reputation), but still resist the term 'respectable' as denoting only upper-class citizen women.

${ }^{101}$ Often cited as evidence for the ideal of the silent and invisible woman. For example: Fantham et al. 1994, 79; Just 1989, 9; Kamen 2013, 95; Schaps 1977, 323; Harris 1995, 237.

${ }^{102}$ Legal speeches: Schaps 1977. Omitowoju (2016, passim) also notes that acts of violence against women are themselves minimised and androcentric in Athenian legal speeches, with naming of a woman or description of her bodily injuries avoided. Comedy: Sommerstein 2009, 43-69; cf. Schaps $(1977,329)$ who says that women were named freely in Athenian drama.

${ }^{103}$ Bremmer $(1981,425-6)$ notes Plutarch's frustration at his inability to name the mothers of prominent Athenian men.

${ }^{104}$ Relaxing of the taboo after death in grave-markers: Osborne 1997, 29-30. Also in legal speeches: Schaps 1977, 326-8.

${ }^{105}$ There are instances of dedications made on behalf of deceased women, notably the practice of dedicating the clothes of women who died in childbirth to Iphigeneia at Brauron (Eur., Iphigeneia in Tauros, 1462-67), and the general practice of dedicating on behalf of another if they are themselves unable to fulfil an oath. But, as stated in Chapter One, without evidence to the contrary, I will assume that the dedication was deposited by the (living) named female dedicator.
} 
Although female names undeniably do not survive to the same extent that male ones do, scholars have recently begun to re-evaluate women's anonymity within their communities. It is clear from votive offerings (and grave markers) that women did have public personas which they were in certain circumstances able to publicise. ${ }^{106}$ Much of the evidence for silent women, and their exclusion from the formal documents through which male identity is typically preserved, reflects ideology rather than the reality of the extent to which women were publicly known. Thucydides' passage may not reflect the words of Perikles, nor the standard of behaviour to which all women were in reality expected to adhere. ${ }^{107}$ Rosanna Omitowoju demonstrates that the law courts, in which women's names were muted, were a constructed setting that, while not "self-consciously fictional," does not reflect reality. ${ }^{108}$ Finally, while women typically are not recorded as historic figures, the names of some eminent women do survive, particularly in the context of religion. When Joan Connelly says that muting of female names has been "overstated" in scholarship (citing David Schaps), she refers to the broad dissemination of priestesses' names within the community. ${ }^{109}$ Indeed, priestesses were so well-known that Aristophanes' Lysistrata is possibly named after a contemporary priestess of Athena Polias, Lysimache, and Thucydides in one instance uses the tenure of a priestess of Hera at Argos to date the beginning of the Peloponnesian war. ${ }^{110}$ The legitimising context of religion allowed all types of living women - not just the elite who were eligible for priesthoods - to be known within their communities. In discussing the anomaly of women's names on dedications, Harris describes the sanctuary as holding a special ideological position that blurs the boundary between public and private, being a public space that was also a forum for activities within women's ideological role. ${ }^{111}$ Yet further, Christiane Sourvinou-Inwood is generally sceptical of women as publicly anonymous, citing grave monuments that praise women as having eukleia (good fame) - an attribute

\footnotetext{
${ }^{106}$ The phrase "public persona" is adapted from Sourvinou-Inwood's use of "social persona" to describe women's public identity in her argument for women as having a presence in the public sphere through religion (Sourvinou-Inwood 1995, 118).

${ }^{107}$ Kallet-Marx $(1993,133-34$; cited by Sourvinou-Inwood 1995, 117) suggests that this is directed to war widows only, so reflects tighter than usual social restrictions. Richter $(1971,3)$ claims the passage is not the words of Perikles but Thucydides, who was prejudiced against women.

${ }^{108}$ Omitowoju 2016, 113-4 and $128 \mathrm{n}$. 41. For more on law being unable to give a complete view of reality see Chapter Three.

${ }^{109}$ Connelly 2007, 57. Although, Schaps $(1977,329)$ does argue for freer naming of women in everyday life than in courts.

${ }^{110}$ Lysimache: Lewis 1955, 6-8. Priestess of Hera: Thuc. 2.2.1, cited by Connelly 2007, 57.

${ }^{111}$ Harris 1995, 237.
} 
predicated on the individual being known by her peers. ${ }^{112}$ However, she concedes that: "If it is correct that 'respectable' women were not named in public, such prohibition was not valid in the sphere of religion." 113 Religion as a forum for the public articulation of female identity is certainly evident in the naming of female dedicators in the votive offerings of the Acropolis. What is more, in keeping with the function of offerings - that is, both to please the deity and praise the dedicator - women used this platform as a means to advertise their social status. Increasingly throughout the course of the Classical period, the most valuable status that dedicants wished to publicise was their stake in the polis as citizens. We can see this interest in declaring one's citizenship in the increased use of the andronymic from the beginning of the Classical period as female dedicators began to regularly display the major pre-requisite for citizenship: citizen parents.

While the unabashed display of female personal names was itself limited in Archaic and Classical Athens, yet more surprising to a view of women as publicly unknown is that women sometimes dedicate in their name alone, without associating themselves with a named male family member. The andronymic, which may name a father, husband, or more rarely a son, does not appear in female votive offerings with any regularity until the advent of the Classical period. ${ }^{114}$ Before c. $480 \mathrm{BC}$ (inclusive), there are only two possible instances of the andronymic out of a total of twenty-eight dedications - and even these two are not totally certain. ${ }^{115}$ Naming a male family member never became a ubiquitous practice, but its frequency did increase after $480 \mathrm{BC}$, appearing on roughly half of surviving dedications after this point (four out of ten) and also just over half of female inventory entries (fourteen out of twenty-five). ${ }^{116}$ I argue that this change

\footnotetext{
112 Sourvinou-Inwood 1995, 117-8.

113 Sourvinou-Inwood 1995, 118.

${ }^{114}$ Umbrella term "andronymic" (cf. patronymic as limited to the father) adapted from Harris's (1995, 237) use of the term "andronym."

${ }^{115}$ Cat. A6: the andronymic itself does not survive, but its existence is almost certain given that, with women not technically deme members, demotics always agreed with the name of a male family member (Gould 1980, 45). Cat. A9: where the dedicator is reconstructed as a woman, the male name is interpreted as a patronymic, i.e. "Philea, daughter of Chairedemos" (Boardman et al. 2004, 277); but this inscription has also been reconstructed as a joint dedication by two men i.e. "Phileas and Chairedemos," or by a single man i.e. "Chairedemos, son of Phileas" (Raubitschek 1949, 226-7).

${ }^{116}$ Cats. A25, A27, A29-30, B2-9, B15-6, B19-21 and B23. 480 BC is the turning point established by Raubitschek (1949, 465-466), although he merely observes the trend without much comment and seems to use this date out of convenience, being the junction between the Archaic and Classical periods; this has been carried through in Dillon (2002, $14 \mathrm{ff}$.). I have also adopted this turning-point out of convenience, but am aware that the dataset is small and the increase at the beginning of the Classical period only slight;
} 
in how women chose to identify themselves was a response to the increasing value of citizenship in the fifth and fourth centuries, as women began to advertise this source of social prestige. This demonstrates the importance of women within their communities, and their willingness to assert their identity within the public sphere - albeit in a way that allowed them to be perceived as appropriately invisible.

\subsection{Questions of demographic}

In interpreting this shift, it must first be established whether the same type of women were choosing to identify themselves differently in the Archaic and Classical periods, or if the demographic of dedicators changed - that is, whether lower class women (particularly non-citizens, who have been viewed as less socially obliged to name a male family member), comprised a larger portion of female dedicators in the Archaic period, with citizen women only beginning to dedicate often in the Classical period. ${ }^{117}$ Any attempt to analyse demographic is unfortunately hampered by the general difficulty of determining the status of any particular woman. The offerings themselves give us some hints, but, in part due to their fragmentary nature, are very limited in the information they can provide.

We can assume something of a dedicator's prosperity from the type of offering she dedicated, with a small terracotta plaque obviously being worth less than a large column monument commissioned from a famous sculptor. ${ }^{118}$ However, as mentioned in Chapter One, the value of an offering did not always directly correlate to the wealth of the dedicator given that, while only the rich could afford extremely expensive dedications, inexpensive offerings were not given only by the poor, as a worshipper would not always dedicate the most elaborate item that their means would allow. ${ }^{119}$ We should also remember at this point that the demographic represented in surviving offerings to Athena on the Acropolis is skewed towards the elite, with many of the offerings dedicated by lower classes made from perishable materials, and being too insignificant to be kept in Athena's temples or recorded. Thus, even the small bronze items in my catalogue, which

\footnotetext{
to suggest a sharp increase after the pin-pointed date of $480 \mathrm{BC}$ would be an exaggeration, with the increase in the andronymic rather being slow and inconsistent.

${ }^{117}$ Non-citizen as more likely to exclude andronymic: Dillon 2002, 18.

${ }^{118}$ Cat. A1, for example, being worth much less than cat. A4, or indeed any of the elite inventory items.

119 Karglou 2010, 49-50; Keesling 1995, 395.
} 
seem less prestigious than the large marble monuments or gold jewellery, still do not represent the lowest class of dedicant.

The offerings in most cases do not provide a dependable way to determine a woman's ethnicity and citizen status. Where an inscription provides a male family member's demotic we can be almost certain that the dedicator, as his kin, was a citizen, given that membership in a deme was perhaps the most rigorous proof of a man's citizen status. ${ }^{120}$ Similarly, an inscription that includes a non-Athenian or non-Greek ethnic associated with either the dedicator herself or a male family member likely marks the dedicator as a non-citizen. ${ }^{121}$ This sort of additional identifying information is, unfortunately, rarely included (as demonstrated by only seven items from my catalogue of sixty three offerings including these community markers). The personal name itself is of limited interpretive use as to citizen status. This is in part because there was no cohesive group of names reserved for Athenian citizens. Some names can be identified as common among Athenian citizens or in Attica (such as Timagora), or uncommon within Attica (such as Iphidike), but personal names are on the whole so flexible that such generalisations cannot be taken as authoritative. ${ }^{122}$ Kostas Vlassopoulos, in his article comparing the names of Athenian slaves and citizens, demonstrates that there can be significant cross-over between vastly different social groups. ${ }^{123} \mathrm{He}$ finds that over half (fifty-three per cent) of known names used by slaves, freedmen and "possible slaves" in the Archaic and Classical periods are attested as also having been used by citizens. ${ }^{124}$ As well as significant cross-over between free and non-free - something that, as Vlassopoulos notes, is surprising given that most Athenian slaves were foreigners - there was also intersection between different areas of Greece. ${ }^{125}$ Thus, while the common usage of a personal name by a certain demographic may give some indication as to the status of individuals who bear that name, I have opted against relying on such inferences, which would be uncertain and require an in-depth analysis of female personal names something that is outside the scope of the this thesis.

\footnotetext{
${ }^{120}$ Demotics: Cats. A6, A9, A29, B7, B21.

${ }^{121}$ Ethnics: Cat. A8 (Phrygia) and Cat. A27 (Aristomarche and Charikleia, daughters of Glaukinos the Argive).

122 Kaltsas and Shapiro 2008, 52 and 59.

${ }^{123}$ Vlassopoulos 2010, passim.

${ }^{124}$ Vlassopoulos 2010, 118.

${ }^{125}$ Vlassopoulos 2010, 118.
} 
The andronymic itself also cannot be read confidently as an indicator of status, despite having associations with citizenship. Matthew Dillon suggests that in the Archaic and early-Classical periods, exclusion of the andronymic does not preclude a dedicator from being an Athenian citizen. ${ }^{126}$ However, he makes a distinction between its use in the physical remains and the late-Classical inventories, suggesting that by the fourth century a woman identifying herself by her name alone should be read as foreign or lower class and those who included the andronymic were "elite." ${ }^{127}$ Dillon's argument builds on that of Harris, who also suggests that women may in the inventories have excluded the andronymic because they were "working-class" - although she is less firm on this hypothesis, also positing that women might be identified by their name alone because they were well-known. ${ }^{128}$ Contra Dillon, she also does not see the association between the andronymic and upper-class women as specific to the period of the inventories, citing as evidence sixth-century bronze fragments from working women who identify themselves by their first name alone. ${ }^{129}$ This distinction between elite and non-elite is difficult to apply to citizenship, as a woman could at once be lower class - taking part in ideologically base activities, such as paid work - and also a citizen (something that Dillon himself acknowledges in respect to the earlier surviving dedication). ${ }^{130}$ Furthermore, while I agree that the inclusion of the andronymic became an important marker of citizen status in the Classical period (see below), I am sceptical of an absolute equation between the lack of a named male relative and a generally lower class (although not necessarily non-citizen) dedicator in any period. Firstly, it seems likely that poor citizens might seek to elevate themselves by advertising their status via the andronymic. An analogy can perhaps be found in the adoption of the demotic by citizen men: while the elite tended to cling to the patronymic, which distinguished them by birth, less socially advantaged citizen were eager to adopt the demotic as, coming from insignificant families, belonging to the polis was their biggest source of social prestige. ${ }^{131}$ Thus, given their otherwise limited social capital, we might expect that at least some lower class citizen women would

\footnotetext{
${ }^{126}$ Dillon 2002, 17.

127 Dillon 2002, 17-18.

${ }^{128}$ Harris 1995, 237.

${ }^{129} I G \mathrm{II}^{2} 401-62$.

${ }^{130}$ Dillon 2002, 17. It should be reiterated that citizenship was just one of many factors contributing to whether a woman might be considered "elite."

${ }^{131}$ Whitehead 1986, 71. More on demotic below.
} 
opt to exploit the continuing prestige associated with Athenian citizenship in the fourth century. Secondly, strict interpretation of the andronymic would be risky for the temple inventories, as we cannot be certain that the exclusion of the andronymic in the surviving inventories reflects its absence in the original votive inscription. ${ }^{132}$ A gold wreath dedicated by Kallikleia, for example, names her husband, Thoukydides, in some entries but not others. ${ }^{133}$ Further, a woman whose name is partially lost is identified as a priestess, but is not named in conjunction with a male relative; as priesthoods were generally reserved for elite citizens, this speaks strongly against a strict interpretation of the lack of an andronymic as marking a woman as lower class in the inventories. ${ }^{134}$ I favour the view of Keesling, who rejects the lack of an andronymic as a tool for determining status altogether, stating:

Although we can determine next to nothing about these women from their dedications alone, I think it is safe to say that women, like men, included their name alone on their $D A A$ dedications with some frequency and for no particular, identifiable reason. ${ }^{135}$

To be clear, the inverse - that is, the inclusion of a named male family member - did have significance as to a woman's identity, increasingly acting as a marker of citizen status in the Classical period. But, at no stage can the absence of the andronymic definitively speak against citizenship.

The question of demographic is again complicated by the slightly different contexts of the two types of evidence. The surviving remains consist mostly of the large stone monuments and smaller bronze objects, all of which were deposited in the open air. The inventory items, on the other hand, were kept inside the sacred buildings on the Acropolis and only periodically extracted for cult use. Although the items themselves were out of sight, their existence was constantly advertised to the public via the inventory lists inscribed on stelai and displayed on the Acropolis. The inventory items are also more

\footnotetext{
132 This is in addition to the pervasive issue of crucial details lost to the fragmentary nature of inscriptions (both those from surviving offerings and the inventory stelai).

${ }^{133}$ Cat. B19 (see Harris VI.66 for all $I G$ entries).

134 Cat. B25.

${ }^{135}$ Keesling 1995, 392; following Aleshire's $(1989,67)$ rejection the assumption that women who did not name a male family member should be understood as courtesans. In her subsequent book on the same subject, Keesling $(2003,76)$ presents a slightly weakened stance, identifying the erratic andronymic as "a persistent epigraphical problem" in interpreting status, and again citing Aleshire, but not going so far as to say there was no reason for its inclusion or exclusion. $D A A$ refers to Raubitschek 1949.
} 
elite in nature than offerings deposited in the open air, and so naturally may have represented higher numbers of citizen dedicators. For one thing, they are exclusively made from valuable materials such as gold, silver, ivory and precious gems (see Catalogue B), indicating that all dedicators named in the treasuries were wealthy. Philto's contribution of an unfired gold nugget emphasises that the most important criterion for inventory offerings - before form, art, or relevance to a particular deity or occasion - was that it be valuable. ${ }^{136}$ This emphasis on value is again apparent in the weights of items made from precious metals being included in many of the inventory entries; it seems to have been imperative that the extent of an item's value was not lost on a viewer who could not see the object itself. ${ }^{137}$ As well as demonstrating elitism through expensive materials, a prestigious level of intimacy with the divine is evident in having one's offering kept inside Athena's temples - especially if we bear in mind that those dedicating in the open air would vie to deposit their offering near a god's temple. The honour of having one's offering subsequently used in state cult, paraded at the Panathenaic procession and so on, is also evident. ${ }^{138}$ Furthermore, the inventory offerings seem to have been at least sometimes associated with undertaking prestigious religious positions that were reserved for elite citizen women. The parthenoi who wove Athena's peplos for the Panathenaia, for example, are said to have dedicated a silver phiale to her temple to mark the end of their service; and indeed, phialai, most often silver but sometimes gold, are the most frequently occurring type of offering from women in the inventories. ${ }^{139}$ There are also two examples of women who identify themselves as priestesses - the most prestigious public position available to women, and typically limited not only to citizens, but specific aristocratic genoi. ${ }^{140}$ Both are quite late, sitting at the cusp of the Classical and Hellenistic periods, so perhaps look forward to the Hellenistic tradition of offerings that explicitly celebrate the tenure of a priesthood. ${ }^{141}$ But these dedications' proximity to the Classical period, and the trend of other sacred duties (such as serving as a parthenos) being celebrated by temple offerings, allow us to speculate that priestesses may have been

\footnotetext{
136 Cat. B13

${ }^{137}$ This desire to preserve an item's value for public appreciation is reflected in the practice of recording the weights of offerings that were melted down (see Chapter One).

138 Treasuries and Panathenaia: Harris 1995, 8-10.

${ }^{139}$ Kaltsas and Shapiro 2008, 36. Phialai: Cats. B1, B8, B10, B15, B16, B17, B18, B20, B21, B24, B25.

${ }^{140}$ Cats. B23 and B25. For more on priestesses see Chapter One.

${ }^{141}$ Connelly 2007, 135-36.
} 
common contributors to temple treasuries throughout the fourth century. There is at least one dedicator recorded in the inventories who is demonstrably elite: Kleito names not only her husband, but also her husband's father and, most impressively, his grandfather - the eminent fifth-century politician and strategos, Kimon. ${ }^{142}$ Conversely, there are also no demonstrably working class or foreign women in the inventory lists (apart from Alexander's wife, Roxane, which is outside of my period), in comparison to the surviving offerings where several women are identifiable as metics or professionals. ${ }^{143}$ Given that inventory items seem to have been skewed towards elite citizen dedicators, we should be alive to the possibility that these women might have chosen to identify themselves differently, being more inclined to put emphasis on their status by including the andronymic.

However, the difference between the surviving and inventory items is not so great that they cannot be approached as a cohesive group. Firstly, there is no positive evidence that allows us to conclusively say that no workers or non-citizens dedicated inside Athena's temples. The surviving offerings make clear that foreign and working-class women could have the means to make elaborate and expensive dedications, so very possibly could have been represented in the inventories. ${ }^{144}$ Indeed, as noted, all of the items in my catalogue skew towards the elite (not necessarily in terms of citizenship, but in having the means to make an expensive offering). We certainly cannot say that grand dedications were exclusive to the inventories, with many of the items deposited in the open air being monumental and ostentatiously expensive. ${ }^{145}$ Large marble monuments were costly - made from a valuable material, requiring intensive labour, and being difficult and expensive to transport. Furthermore, value could be added by highlighting the commissioning process: Iphidike's offering serves as an example of a self-consciously expensive open-air dedication, with the dedicator emphasising in the votive inscription that she commissioned the monumental marble offering from the famous Chian sculptor

\footnotetext{
142 Cat. B5.

${ }^{143}$ Roxane: V358. Metics: Cats. A8 and A27. Professionals: Cats. A8 and A18. Also see Chapter Three on first-offerings as denoting paid work.

${ }^{144}$ For more on possibility of worker in the inventories see Chapter Three.

${ }^{145} \mathrm{Cat}$. A1 is the exception to this, with pinakes being relatively inexpensive.
} 
Archermos. ${ }^{146}$ Bronze items were also inherently valuable due to their material although, admittedly, not valuable to the extent of their gold and silver equivalents in the inventories. Still, bronze items' worth is evident in the instances where they were melted down and repurposed - as opposed to offerings from cheaper materials that were merely deposited in pits. ${ }^{147}$ In addition to the value of surviving items being roughly comparable to those in the inventories, the dedicators in both contexts also behave similarly, with the trend towards the inclusion of the andronymic had already began in the physical remains of the early-mid Classical period. ${ }^{148}$ I think that these two factors allow us to see the inventory items as a slightly differentiated (that is, somewhat more prestigious) continuation of the physical remains, rather than a distinct group.

Finally, a continuous demographic is more appealing simply on the basis that it seems very unlikely that the two women who named a male family member in the Archaic period were the only citizens to dedicate on the Acropolis before $480 \mathrm{BC}$ - even accounting for the evidenced participation of socially marginalised groups on the Acropolis at this time. This is especially true seeing as these two instances of the andronymic (both of which also include the male relative's demotic, so were beyond doubt dedicated by citizens) demonstrate that it was permissible for wealthy citizen women to dedicate on the Acropolis at this time. Given this permissibility, we would perhaps expect the elite to welcome the opportunity to publicly display their wealth and social standing - after all, they, more than any other group, possessed sufficient resources and prestige to successfully engage in the one-upmanship inherent in votive offerings.

In sum, due to similarities between the two types of evidence and the absence of positive evidence for a break in demographic, we can assume that the demographic of dedicators remained generally constant between the surviving items and inventory lists, with a range of women - both citizen and non-citizen - dedicating throughout the period that this thesis covers.

\footnotetext{
${ }^{146}$ Iphidike: Cat. A4. Cat. A5 also names the artist, now unknown but presumably prestigious in antiquity. Dillon $(2002,15)$ in particular reads the naming of an artist as advertising that an item was "specially commissioned and expensive."

${ }^{147}$ See Chapter One.

148 Cats. A25, A27, A29 and A30.
} 
2.3 Possible motivations for using the andronymic

We must now turn to why female dedicators, who always included citizens and noncitizens, began to identify themselves by the andronymic regularly only at the advent of the Classical period. There are, in my view, three possible reasons for an Athenian woman to include her andronymic: firstly, so that she might represent herself as appropriately dominated by the authority of her kyrios and obscure her own independent identity, the unabashed disclosure of which would stain her good reputation; secondly, so that she might be identified in the public sphere from which she was personally excluded, but where her male family members would have been well-known; or thirdly, to be elevated, in her own right, by asserting her citizen status, as evidenced by a citizen father or husband. While the first two of these may have contributed to the desirability of including an andronymic, I argue that female dedicants were primarily motivated by a desire to advertise citizenship as the value of this status increased with the rise of the Athenian 'empire.'

\subsubsection{Adherence to ideology}

The first contributing factor, the subordinating effect of the andronymic, has been given the most weight by scholars. Harris sees the practice as reflecting the androcentric nature of Classical society, in which men were the sole figures of public importance. ${ }^{149}$ Indeed, we cannot deny that an Athenian woman's public identity was often tethered to that of a man, while a man is never identified by his relationship with a woman. ${ }^{150}$ Dillon goes further to interpret the increased use of the andronymic not just as a general symptom of male-centric Athenian society, but rather a sign of tightened restrictions placed on women's lives and the erosion of independent female identity in the Classical period. ${ }^{151}$ This builds on the traditional view of the Classical period as being more restrictive for women; the advent of democracy in particular has been interpreted as having disempowered Athenian women by shifting social authority from being founded on prominent $o i k o i$, in which they played a key role, to the polis, which gave precedence to

\footnotetext{
149 Harris 1995, 237.

${ }^{150}$ Sommerstein $(2009,46)$ notes a passage of Ar. Thesm. (603 ff.) where the questions 'Who are you?' and 'Who is your husband?' appear to be interchangeable.

${ }^{151}$ Dillon 2002, 15.
} 
the active male citizen. ${ }^{152}$ However, the democracy concurrently elevated citizen women just as it made their position more restricted. Perikles' citizenship law of $451 \mathrm{BC}$, which required a citizen to possess both an Athenian mother and father, in effect codified the privileged position of citizen women within the community. However, it has also - I think accurately - been seen as increasing pressure on women to protect their reputation by conforming to gender ideology. ${ }^{153}$ With women excluded from official registration in the formal institutions of democratic Athens - the phratry and the deme - it was difficult for a woman to prove that she was a citizen; the only means left to her were to demonstrate it, apart from proving citizen parentage, was to boast a reputation for having acted in a citizen-like way. ${ }^{154}$ Thus, the andronymic allowed a female dedicator to publicly align herself with the ideological model of the submissive, male-dependant woman. The andronymic is not the only aspect of Classical dedications to indicate a desire for women to appear appropriately invisible. Keesling has identified a simultaneous shift away from monumental dedications deposited in the open air towards smaller, less visible offerings deposited in Athena's temples, which she sees as a tightening of etiquette surrounding ostentatious statements of female identity. ${ }^{155}$ As well as inventory items being less overtly visible to the general public, the temple itself may have been considered a feminine space - making it an even more appealing dedicatory space for women interested in being seen as behaving in an appropriately feminine way. ${ }^{156}$

Despite this increased interest in appearing subordinate and invisible, I think that both Harris and Dillon overstate the minimisation of independent female identity in Classical dedications. Firstly, this shift reflects a trend that permeates my thesis: women's behaviour was focused as much on the appearance of adhering to ideology as the genuine restriction of their activities; this is not to say that there were no genuine restrictions on women, but merely that their actual behaviour was much freer than even they themselves

\footnotetext{
152 Pomeroy 1975, 78; Cohen 1989, 3 and 13 n. 1; Fantham et al. 1994, 39 and 74-5. Blundell 1995, 129; Raaflaub 1998, 33-4; van Wees 2003, passim. Cf. Sourvinou-Inwood (1995, 112) who argues for women's subordination within the oikos.

${ }^{153}$ Raaflaub 1998, 36.

${ }^{154}$ Sealey 1990, 14; Raaflaub 1998, 36; Cohen 1998, 60-1.

${ }^{155}$ Keesling 2003, 77. Dillon (2002, 17-8) also notes that dedications from women become "less public in nature" by moving to the inventories, in contrast to those from men, which continue to be dedicated in the open-air.

${ }^{156}$ The temple as a feminine space is perhaps reflected in female deities having temples erected before their male equivalents, with the latter's early sanctuaries consisting of an altar in the open-air (Davidson 2011, 610).
} 
wanted it to appear. Although motivated by increasing pressure to act in a 'respectable' way, the inclusion of the andronymic and moving of offerings inside the temples marginalised independent female identity in appearance only. The real value of independent identity actually increased for citizen women in the Classical period as an inadvertent result of Perikles' law, with the woman's status being something that that votive offerings celebrated (as will be discussed below). There was also little real restriction on Classical women's ability to dedicate. Women could still make grand offerings of valuable objects and advertise prestigious aspects of their personal identity through inscription (such as Kleito's naming of her husband's famous grandfather, or the two priestesses' mention of their esteemed religious positions), ${ }^{157}$ they were merely compelled to begin doing so in a more discreet way, with their piety and wealth communicated to the public through the more austere and less immediate inventory lists. Secondly, the Athenians had no qualms with omitting a woman's personal name altogether, and, as noted above, this was in fact the norm for most public references to living 'respectable' women. If Classical votive offerings aimed to indicate that a female dedicator was invisible, unimportant, and had no identity independent of her father or husband, we might expect that the andronymic would replace the female personal name entirely. But, there are only three examples of identifiably female dedications where the woman's personal name is unknown, and in two of these instances it is only because this crucial part of the inscription has been lost. ${ }^{158}$ While perhaps a contributing factor, marginalisation of independent female identity in order to make a dedicator appear more 'respectable' is unlikely to have been the primary aim of the andronymic, even if only because it is not effective in achieving this goal.

\subsubsection{Identification}

This brings us to the second possible motivator - that a male name was necessary for identification. This section should be prefaced with the acknowledgement that literacy was never widespread in Athens, so identification of a dedicator via an inscription was never universal. But, where a dedicator is named, their personal identity was an important

${ }^{157}$ Cats. B5, B23 and B25.

${ }^{158}$ Name excluded: Cat. B15. Name lost: Cat. A29 and A30. 
component of votive offerings. ${ }^{159}$ Keesling notes a tendency to place personal names at the beginning of votive inscriptions from monumental offerings, or to formulate them in a way that allowed a reader to pull the name out of the text at a glance, emphasising identification of a named individual as the votive inscription's key function. ${ }^{160}$ While women's naming of men had an ideological component, the need for identification was also practical - indeed, men similarly included the patronymic as an identifier with some regularity. ${ }^{161}$ While the strict physical seclusion of women within the oikos has been rejected, scholars tend to agree that separation of the sexes was fundamental to Athenian society. ${ }^{162}$ This ideal of separation meant that (at least in theory) there would have been few opportunities for 'respectable' women to engage socially with, or even be seen by, men. And in practice, this was often the case, as even a cursory look at the separate progressions of boys and girls through to adolescence and adult life will testify. Thus, we might be tempted to conclude that women needed to name a male family member because they would not be known to non-kin men by their personal name alone. This is something that Schaps suggests in his discussion of the identification of women in the law courts, saying: "...if she was a proper woman, the jurors would not be expected to know her, but would be expected to know her kyrios." 163 However, Schaps' statement is steeped in ideology, indicating that women should not be known, rather than that they in practice were not: "It is clear that the orators are not calling the women by their customary names, but avoiding them, when they tell us whom they married."164 In line with Schaps' qualification, I argue that that Athenian woman in many cases could be recognised by her personal name alone, as, contrary to ideology, women did have an independent presence in the public sphere.

The exceptional case of priestesses, grave-markers, and votive offerings themselves have already been discussed as evidence of recognisable independent female

\footnotetext{
${ }^{159}$ An offering did not need to include an inscription or name the dedicator; it seems that the god would know from whom the gift was given regardless.

${ }^{160}$ Keesling 2003, 32-4.

${ }^{161}$ See below for more on male naming patterns.

${ }^{162}$ See Chapter One.

${ }^{163}$ Schaps 1977, 330. Also, Sommerstein $(2009,48)$ : "A woman was supposed to have, in her own right, no public role and no public personality."

${ }^{164}$ Schaps $(1977,329)$. Cf. Sommerstein $(2009,62)$ who sees restrictions in the use of the personal name as applicable to life generally: "In the streets as much as in the courts, before one's neighbour as much as before a jury, to name such a woman in public, without pressing necessity, was to degrade and dishonour her."
} 
identity. Additionally, the reality of regular contact between women and members of the wider community (both male and female) speaks for women's personal names as having the ability to identify an individual. The existence of social networks between women is widely accepted - from the fountain or spring being a hub of communal gossip, to the custom of aiding one another during what Goff terms as "crises of the oikos" (that is, death, childbirth, and illness), or feasting and performing ritual together during womenonly religious festivals. ${ }^{165}$ Indeed, Alan Sommerstein notes that in comedy women freely use the personal names of female peers (even when in the company of men), suggesting that it was ordinary for women to be aware of and use other women's personal names. ${ }^{166}$ It is also possible that women's personal names may have been known to non-kin men within their immediate community. The most obvious instance of women regularly engaging with members of the opposite sex can be found in those who worked outside the home. Roger Brock suggests that there was no physical separation between genders in marketplace or workshop, citing the saleswomen of Aristophanes' Wasps (493-9) and Lysistrata (555-64) who appear to engage freely with men in the agora. ${ }^{167}$ This leads us to think that the working women represented on the Acropolis - such as Phrygia and Smikythe - may have excluded the andronymic simply because, having engaged openly with both sexes in the course of their trade, it was not needed for identification (and, indeed, their profession may have been more publicly recognisable than their father or husband's name). ${ }^{168}$ Beyond this, even upper class women's personal names could have been known by non-kin men. Likely (though contested) is the regular introduction of citizen wives to their husband's phratries as part of the legitimisation of a citizen marriage at the Gamelia, as well as daughters' introduction to their father's phratries (although, the latter appears to have occurred only in select phratries and where the daughter was destined to be become an epikleros). ${ }^{169}$ Given the little surviving evidence regarding this process, we cannot know whether the bride was introduced by her own name or that of her father. ${ }^{170}$ Pomeroy, for instance, suggests that, even if women were introduced (which

\footnotetext{
${ }^{165}$ Women's communal activities: Gould 1980, 49; Cohen 1989, 7; Fantham et al. 1994, 109-11; Blundell 1995, 137-8; Burton 1998, 150 ff.; Goff 2004, 26-69.

166 Sommerstein 2009, 44.

${ }_{167}$ Brock 1994, 345-6.

${ }^{168}$ Cats. A8 and A18.

169 Women and girls' involvement in phratries summarised in Lambert 1993, 36-7 and 178-188.

${ }^{170}$ For primary sources see: Lambert 1993, 182-3.
} 
she contests), their names would not have been given, citing a decree of the Demotionid phratry that advises against the mother being named when boys are introduced, instead prescribing that the name and demotic of the mother's father be given. ${ }^{171}$ But the function of presenting a bride at the Gamelia - that is, to safeguard citizenship by confirming the status of a potential mother of citizens - foregrounds female identity in a way that might allow us to reasonably believe women's personal names were given. Perhaps comparable is the naming of both the father and mother during the formal examination of candidates for the nine archonships; here, as the scrutiny is again designed to confirm an individual's citizen status, the name of the mother, as well as the name and deme of her father, are required. ${ }^{172}$ If nothing else, as Raphael Sealey notes, refusal to use the female personal name in official contexts such as these has the potential to cause "infinite regress," as male family members of increasingly distant relation are cited to affirm citizen status (the grandfather to affirm a mother's status, the great-grandfather to affirm the grandmother's status and so on). ${ }^{173}$ What is more, ritual provided a forum for women to be known within their communities, with prestigious religious roles (such as priesthoods, but also the arrephoroi, parthenoi, and kanephoroi), performing in choruses, and dining at feasts providing opportunities for women to be displayed as individuals before the wider community. The latter two have even been viewed by scholars as socially significant, being events that allowed socially sanctioned mixing of the sexes and so facilitated courtship. ${ }^{174}$ Thus, while recorded female personal names are absent from most nonreligious contexts, it seems likely that these were known by at least a reasonable portion of the community but merely withheld. ${ }^{175}$ Indeed, the possibility for women to be personally known by their non-kin contemporaries is acknowledged by Harris, who suggests that "well-known" women might not need the andronymic in order to be recognised. ${ }^{176}$

\footnotetext{
${ }^{171}$ Pomeroy 1995, 118: IG $\mathrm{II}^{2}$ 1237, lines 119-20.

172 Sealey 1990, 13, citing Ath. Pol. 55.3.

173 Sealey 1990, 14.

${ }^{174}$ Courtship at feasts: Evans 2004, 15. Choruses as displaying girls of marriageable age: Goff 2004, 85 ff.

175 Sommerstein $(2009,61)$ suggests that withholding the personal name "was waived where the naming of the woman was essential to establish her identity or status or that of a child of hers." This is in the context of comedy, but Sommerstein generally applies his findings more broadly to Athenian life.

176 Harris 1995, 237. Connelly 1996, passim.
} 
Having said this, I must be careful not to overemphasise the notoriety of the average Athenian woman. With stigmas deterring women from allowing themselves to appear well-known, diverging life-patterns separating men and women, and men's natural position being outside the home while women's was inside it, it is certain that men were known more widely in the public context than women. Although it would have been possible for women to be identified by their personal names alone, it may have been more desirable for votive offerings to identify female dedicators to as wide an audience as possible by including the name of a man who had a broader social reach than herself. But, given women did not need the andronymic for identification, this slight increase in accessibility does not seem strong enough to be the primary motivator towards its adoption. Indeed, if it did aid identification, the question would remain as to why the andronymic came into wide usage only in the Classical period; surely an Archaic dedicator would be as eager to receive credit for an impressive offering as a Classical one. An answer may perhaps be found in the general confidence of the mid- to late-Classical period, which led to more emboldened interactions between the Athenians and their gods. Eugenia Vikela, for example, argues that the increased religious confidence of Classical Athens can be seen in a lack of reverence shown by the relative depictions of mortals and gods in votive reliefs, with one Classical example representing the humans as standing very close, and being of a similar size, to Athena while making sacrifice. ${ }^{177}$ If the dedicator did loom larger in the minds of Classical worshippers than she had previously, this could explain an invigorated emphasis on identification of the dedicator. But, still, this alone does not seem compelling enough to be the sole driving force behind the emergence of the andronymic. Instead, increased identification was rather a happy result of, or, like the desire for apparent invisibility, worked in tandem with, what I see as the most forceful motivator toward the andronymic: the increased value of female citizenship in Classical Athens.

\subsubsection{Increased value of female citizenship}

To explore this final factor we must establish that Athenian women enjoyed independent citizenship in their own right, rather than quasi-citizenship dependant on the status of her father or husband. The traditional view, still held by some scholars, is that, to the

177 Vikela 2005, 93-5 and 156-9, cited by Avramidou 2016, 17. Athens' theophilia: Garland 1992, 11. 
Athenians, full citizenship was reserved for adult men who were eligible to participate in the political, legal and military workings of the polis. ${ }^{178}$ This assumption is formed in part due to the liberal application of Aristotle's Politics (1275b19-21), written in the late fourth century, to the Archaic and Classical periods. ${ }^{179}$ In this text, political agency is foregrounded as a pre-requisite of citizenship, with a citizen defined as: "He who has the power to take part in the deliberative or judicial administration of any state is said by us to be a citizen of that state." 180 An increased emphasis placed on the active male citizen, or polites, in Athenian thought from the mid-fifth century onward has been interpreted as supporting an Aristotelian reading, as has a perceived lack of vocabulary for female citizens. ${ }^{181}$ Other scholars have acknowledged the centrality of Athenian women to the polis, despite their lack of political agency, by attributing to them citizen status that is "passive" or "latent". ${ }^{182}$ This accounts for women's role as passive conduits of citizenship, being the bearers of male citizen children, as well as the active citizenship that women sometimes exhibited in a special circumstances, namely when participating in state religion. ${ }^{183}$ However, I follow Josine Blok and Cynthia Patterson who assert that Athenian women would have been understood as holding full, independent citizenship that was analogous, though different, to that of men. ${ }^{184}$ This position is based on three main points: firstly, that it is inaccurate to retroactively apply Aristotle's formula to sixth, fifth, and even early-to-mid fourth century concepts of citizenship; secondly, that the contemporary vocabulary of citizenship had the capacity to include women; and thirdly, that women were able to meet the actual conditions of citizenship - legitimate parentage

\footnotetext{
${ }^{178}$ Complete denial of female citizenship: Loraux 1993, 116-23. Formal exclusion from citizenship due to pre-requisite of political agency, but acknowledgement of women's centrality to polis: Whitehead 1986, 77-81 and 258; Just 1989, 23; Raaflaub 1998, 32-3.

${ }^{179}$ For reliance on Aristotle: Patterson 2005, 267-268; Blok 2005, 8 n. 7.

180 Trans.: Patterson 2005, 267.

${ }^{181}$ Loraux (1993, 116 and 119) asserts that "the word for 'female Athenian' does not exist" and subsequently, that "...there is no such thing as a 'female citizen,' any more than there is a 'female Athenian'.” Cf. Patterson and Blok (see below). For further comprehensive overview of scholarship's emphasis on political rights (and further bibliography): Blok 2017, 30-6.

182 "Passive": Sourvinou-Inwood 1988, 112. "Latent": Sealey 1990, 14; Goff 2004, 164. Limited (i.e., non-political) citizenship: Todd 1993, 201; Fantham 1994, 74; Blundell 1995, 128-9.

${ }^{183}$ Sourvinou-Inwood $(1988,112)$ describes female citizenship as passive because it was only available during cult; Goff (2004, 164, adapting Sealey 1990, 14 and Detienne 1989) sees it as active but latent, because, although women only engaged with the state in the contexts of cult and legitimate childbirth, the potential to act as citizens in this way was always there.

${ }^{184}$ Patterson 1981, 151-174 and 2005, passim; Blok 2005, passim, 2009, 158 ff. and 2017, 3. Explicitly following Patterson and Blok: Cohen 2015, 175-7; Borgers 2008, 73; Kamen 2013, 89-97 (also, I think, implicitly those above who argue for non-political female citizenship).
} 
and exercising one's share in the polis along gender appropriate lines (which for women, meant taking part in state ritual).

Beginning with the issue of Politics, this text was not a targeted analysis of Athens' political history. Rather, it was a philosophical exercise that laid out Aristotle's political theory, with the aim of identifying an ideal political system that might be able to respond to the upheaval he experienced during his life at the cusp of the Classical and Hellenistic periods. ${ }^{185}$ In addition to never being intended as a historical account of Athenian history, the work was written in the late fourth century, so temporally removed from - and thus unlikely to reflect - the Archaic and Classical periods during which the concept of citizenship was being constructed and adapted, often in a nebulous and loosely-codified way. ${ }^{186}$ Indeed, contemporary evidence reveals an understanding of citizenship that could include women, even as it increasingly distinguished between the practical manifestation of the male and female citizen.

We can see concepts of what it meant to be Athenian emerging as early as Solon's laws, which afforded special benefits to those who belonged to the polis - namely that they could not be enslaved against their debt and had the right to recourse in the law courts. ${ }^{187}$ The lack of clarity in early concepts of citizenship is already evident, as, despite the practical need to define 'Athenian' in order to determine who enjoyed the privileges laid out by Solon, pre-requisites of citizenship were not formally established at this time; we can, however, infer that Solonian citizenship included women, as neither an Athenian man nor woman could be enslaved. ${ }^{188}$ Even Kleisthenes, when he established the deme system in $508 \mathrm{BC}$ and set in motion the mechanics of democracy, did not codify any qualifiers for citizenship. ${ }^{189} \mathrm{We}$ can perhaps see the emergence of a gender divide in terms of civic participation at this point, with men officially enrolled in deme lists while women were not; and this divide grew even further with Ephialtes' reforms of $462 \mathrm{BC}$, which extended the capacity of male citizens to actively participate in the assembly and law courts. ${ }^{190}$ Still, as I will argue below, this increased awareness of what it meant to be a

\footnotetext{
185 Blok 2005, 31-35 and 2017, 13-21.

186 Patterson 2005, 268.

187 Patterson 2005, 271-2.

188 Patterson 2005, 272-3.

189 The default criteria seem to have been citizen parentage and residence in Attica at the time of the reform, but, again, this was not formally stated. Block 2005, 278; Patterson 2005, 278.

190 Patterson 2005, 278; Rhodes 1981, 304-18.
} 
male citizen does not in itself undercut the status of women as citizens. Perikles' citizenship law of $451 \mathrm{BC}$ is the first instance of any pre-requisite of citizenship being laid down in law: that a person must have two citizen parents - or two astoi, as it is phrased in the Athenaion Politeia (26.3). ${ }^{191}$ This criterion of descent certainly has the capacity to include women, and the language of the law seems to equate the statuses of the mother and father by requiring two astoi, rather than using different terms to distinguish between a citizen man and merely geographically or genetically local woman. Perikles' law was later loosened during the final years of the Peloponnesian War, when adult male citizens where scarce; in what was likely a broader practice, Perikles, having lost his legitimate sons, successfully made an illegitimate son his heir, and there is some evidence (though questionable) of a law that allowed citizen men to have legitimate children with citizen women other than their wives. ${ }^{192}$ But, in 403 BC, after the Thirty Tyrants had been expelled from Athens, the criteria of two (married) citizen parents was reasserted for children born after that date. ${ }^{193}$ Thus, it is evident that what it meant to be a citizen fluctuated during the period covered by this thesis, and so cannot be restricted to Aristotle's retroactive and prescriptive definition. More immediate contemporary evidence in fact indicates that even the very first concepts of what it meant to be Athenian included women, as Blok observes that citizenship was based on the pre-requisite of descent and amplified by appropriate participation in the polis (which meant religious activity for all, in addition to political engagement for men). ${ }^{194}$

Indeed, women's status as citizens only grew stronger and more explicitly articulated throughout the Classical period. In a context of increasing emphasis placed on the active male citizen, Perikles' law had a balancing effect by elevating the status of citizen women. Both Patterson and Blok see 451 BC as a key moment for citizen women, being the point at which they formally became indispensable to the continuation of the

\footnotetext{
${ }^{191}$ Alternatively, Plu. Per. 37.3 uses the term Athenaioi (cited by Patterson 2005, 268).

192 Kennedy (2014, 17-18) sees enfranchisement of Perikles' son as indicative of a much broader practice; Plu. Per. 37.ii-v, cited in Rhodes 1981, 332. Bigamy: D.L. 2.26, cited by Patterson 2005, 284; cf. Sealey (1990, 171 n. 10) who dismisses bigamy laws as "fanciful."

${ }^{193}$ The decrees of Nikomenes (schol. Aischin. 1.39) and Aristophon: (Ath. 13.577c), cited in Sealey 1990, 171 n. 11.

${ }^{194}$ Blok 2017, 1.
} 
polis. ${ }^{195}$ Further, the value of citizen women as marriage partners became yet more legally entrenched after the reaffirmation of Perikles' law at the end of the fifth century, with marriage between a citizen and non-citizen outlawed from at least the mid-fourth century. ${ }^{196}$ Before this, such marriages had likely been legal - just unappealing due to their inability to produce citizen children. ${ }^{197}$ Indeed, the enduring importance of the citizen mother in the fourth century is explicit in legal speeches where a woman's status is questioned. In Against Euboulides, for example, Euxitheos must assert his citizen status, his name having been struck off his deme list. As well as citing his own citizenlike behaviour, including participating in his deme and being eligible for civic office (Dem. 57.47-49), and that of his father (Dem. 57.25), he also defends against the suggestion that his mother was not a citizen (Dem. 57.30-36); here, the status of the woman is essential in confirming that of the son. In Against Neaira it is a woman herself who is being prosecuted, having allegedly presented herself as a citizen in order to enrol her non-citizen sons in phratries and marry her non-citizen daughters to Athenian men. ${ }^{198}$ Again, the woman's independent status is important, not only for herself but also as a prerequisite for the eligibility of her children (both male and female) to participate in the community.

Furthermore, Blok and Patterson establish that the vocabulary to describe female citizens was always available, although male and female terms began to diverge in meaning as the gendered nature of civic participation came to the forefront of Athenian consciousness toward the end of the fifth century. ${ }^{199}$ There are three main terms for the female citizen - aste, politis, and Athenaia. For the sixth and majority of the fifth centuries, the masculine plural astoi was the primary term for a group of citizens. Astoi, derived from astu (city) was often used in contrast to xenoi (foreigners) so seems to denote being an insider of the city without any particular political connotations. ${ }^{200}$ More importantly, the masculine plural astoi could be used for a group that included women,

\footnotetext{
195 Blok 2009, 159; Patterson 2009, 268. Kennedy (2014, 26 ff.) also strongly makes this argument, although from the perspective of its detrimental impact on metic women. Previously, citizen children needed only a citizen father (Todd 1993, 177)

196 There is little surviving direct evidence, but Against Neaira (Dem. 59) is premised on mixed marriages being illegal (Sealey 1990, 16; Kennedy 2014, 20).

${ }^{197}$ Rhodes 1981, 332; Kennedy 2014, 20.

${ }^{198}$ Dem. 59, cited by Patterson 2005, 288.

199 Blok 2005, passim and 2017, 147 ff.; Patterson 1981, 151-74 and 2005, 268-70.

${ }^{200}$ Blok 2005, 15-16; Patterson 2005, 169; Patterson 1981, 156-7.
} 
as we have seen from its use in Perikles' law. The feminine plural of astai is also attested, and is the most common word for a group of female citizens. ${ }^{201}$ It was not until the second half of the fifth century that the singular form astos, and its feminine form aste, began to appear, perhaps reflecting a growing conception of citizens as individuals who actively fulfilled the duties, and enjoyed the benefits, of being an insider of the community. ${ }^{202}$

The alternative masculine plural politai, derived from polis, was in the Archaic and early Classical periods synonymous with astoi - that is, it bore no political connotations and was inclusive of both genders. ${ }^{203}$ From the second half of the fifth century, politai rose to become the preferred term for a group of citizens, with this, and its masculine singular form polites, eventually established as the dominant term for the male citizen by the fourth century. ${ }^{204}$ At the same time as this rise in popularity, the masculine forms, politai and polites, came to reflect the strict Aristotelian sense of citizens as those who were judicially and politically active within the polis. ${ }^{205}$ Here we can see the first ideological distinction between masculine and feminine forms of citizen terminology, as the feminine forms, politis and politides, did not denote political rights (for women had none), but instead, like aste, merely framed the woman as an insider of the community. ${ }^{206}$ Furthermore, aste remained the primary term for the individual female citizen, even as polites surpassed astos for the male citizen. ${ }^{207}$ Again, this divergence along gender lines need not undermine an argument for female citizenship, but rather reflects an increased awareness of the gendered nature of citizenship as Athens became more conscious of herself as a democracy. ${ }^{208}$

The most formal term to describe a group of Athenian citizens, appearing regularly in official documents, was Athenaioi. ${ }^{209}$ The official public contexts in which the masculine plural was often used meant that it typically excluded women. ${ }^{210}$ However,

\footnotetext{
201 Patterson 1981, 161.

202 Blok 2005, 14-15.

${ }^{203}$ Blok 2005, 12.

${ }^{204}$ Blok 2005, 8, 15-16; Patterson 1981, 153.

${ }^{205}$ Blok 2005, 12; Patterson 1981160 and 172 n. 28.

206 Patterson 1981, 161.

207 Patterson 1981, 161

${ }^{208}$ Blok 2005, 20 and 29-30; Patterson 2005, 269.

${ }^{209}$ Patterson 1981, 162.

${ }^{210}$ Although, an exception can be found in Plutarch (Per. 37.3) use to describe the parents of citizen children under Perikles law (Patterson 1981, 162-3).
} 
there are several instances of the feminine plural Athenaiai from the fifth and fourth centuries. $^{211}$ The most notable of these is in the decree establishing the priesthood of Athena Nike, which states that the candidate will be chosen from all Athenaiai. ${ }^{212}$ Here, we see the feminine form acting in the same way that the masculine would, in that it describes the type of person who may engage with the polis as a member of its community. ${ }^{213}$ The feminine singular Athenaia is very uncommon, though Blok suggests that this may be because women wished to avoid offending Athena by using a variation of her name to describe themselves. ${ }^{214}$

In addition to the specialised terms (both masculine and feminine), citizenship was often phrased as 'having a share in the polis' ( $\mu \varepsilon \tau \varepsilon \dot{\chi \varepsilon \varepsilon v} \tau \tilde{\eta} \varsigma \pi$ ó $\lambda \varepsilon \omega \varsigma$ or $\mu \varepsilon \tau \varepsilon \dot{\chi} \chi \varepsilon v \tau \tilde{\eta} \varsigma$ $\pi \mathrm{o} \lambda\left(\tau \varepsilon \dot{\alpha} \alpha_{\varsigma}\right) .{ }^{215}$ This brings us to the final affirmation of female citizenship: that, aside from descent from citizen parents, the second major marker of citizenship was participation in the polis, with religion being an essential forum in which citizens could participate. As Nancy Evans says:

Participation in the cultic democracy defined the citizen (male and female), and reinforced a citizen's identity as a member of a family, of a phratry, of a deme, and of the polis. ${ }^{216}$

While men had a variety of means through which they could exercise their 'share' in the polis - via law and politics, as well religion - women did so by primarily by taking part in ritual. However, this does not mean that the social value of women's civic contribution should be underestimated, with women's religion being central to the wellbeing of the polis. Women-only festivals, such as the Thesmophoria, Adonia, and Lenaia, facilitated the fertility that underpinned the community - both that of the female participants who produced the next generation of citizens and of the fields that sustained the state. ${ }^{217}$ The intimacy of these festivals with the interests of the polis is particularly evident in the Thesmophoria. This festival may not have consisted of a city-wide event, rather

\footnotetext{
${ }^{211}$ Blok 2005, 26 n. 104.

${ }^{212} I G \mathrm{I}^{3} 35$. Blok 2005, 26.

${ }^{213}$ Blok $(2009,166)$ emphasises the connotation of independent citizenship here, as the women are called Athenaiai, rather than wives of Athenians.

${ }^{214}$ Blok 2005, 27-28.

${ }^{215}$ Blok 2005, Patterson 1981, 164-6 and 2005, 270.

${ }^{216}$ Evans 2004, 24.

217 Overview of women's festivals: Fantham et al. 1994, 83-96; Blundell 1995, 160-9.
} 
consisting of smaller gatherings grouped according to deme. ${ }^{218}$ Either way, the festival was tightly linked to citizenship and the informal association between a woman and her kyrios' deme. Isaios (3.80) indicates that participation in the festival was not only limited to citizen women, but practically compulsory for them, with all citizen men of means required to fund their wives' engagement in the Thesmophoria. ${ }^{219}$ Indeed, Robert Parker suggests that the Thesmophoria functioned much like the Apatouria as an informal register of citizenship. ${ }^{220}$ Eligibility for priestly office was another marker of the citizen. ${ }^{221}$ Although old religious offices were reserved to members of elite families, as the democracy grew stronger and Athenians more confident in themselves as citizens, democratisation of religion occurred. This is reflected in the priesthood of Athena Nike on the Acropolis, established by decree in either the 440s or $420 \mathrm{~s} \mathrm{BC}$, with candidates drawn from all citizen women, not just those from elite families. ${ }^{222}$ Indeed, there is a clear equivalence between citizen men's eligibility for state offices - whether it be political or religious - and citizen women's eligibility for religious office; just as Euxitheos used his nomination for a priesthood as evidence of his citizen status in Against Euboulides, a woman could reference her nomination for the priesthood of Athena Nike in the same way.

In sum, I think that Blok and Patterson convincingly demonstrate that Athenian women were independently capable of meeting the two main criteria of citizenship: descent from citizen parents and engagement with the polis. Further, I think that it is too soft to call women's citizenship "passive" or "latent." Women were not the passive recipients of citizen status derived from their father or husband, but were themselves the source of their children's eligibility to be members of the polis from at least $451 \mathrm{BC}$. Quite the opposite of passivity, women were also the active facilitators of agrarian fertility through cult, as well as some of Athens' most important religious leaders. Citizen women retained their value as citizens even when not actively participating in the polis via legitimate childbirth or religious activity, with eligibility for civic participation being sufficient to emphasise women's identity as citizens even when they were not directly

\footnotetext{
218 Whitehead 1986, 80.

${ }^{219}$ Discussed by Goff 2004, 75.

${ }^{220}$ Parker 2007, 272.

221 Sourvinou-Inwood 1995, 116.

222 Blok 2009, 165-8; IG I 35.
} 
taking part (just as it was for men). ${ }^{223} \mathrm{I}$ accept that Athenian thought increasingly gave precedence to the male citizen as Athens' understanding of herself as a democracy developed, and that men consistently enjoyed unfettered engagement with the public sphere, whereas women were largely restricted to religion in terms of how their share in the polis could be manifested. But, it is also clear that Athenian women held a very special position within their community - a position so special, and so intimately related to their share in the polis, that we can comfortably describe them as citizens in their own right.

Having established independent female citizenship, there is a convincing case for the andronymic as reflecting the increased prestige of female citizenship from the middle of the fifth century. For one thing, the advertising of female citizenship also occurred in grave-markers at a similar time. Robin Osborne, in his article analysing women's representation in funerary monuments, makes a similar argument. ${ }^{224}$ He suggests that an increase in grave markers commemorating women from the mid-fifth century reflects the increased social value of citizen women after Perikles' reform, and that men were eager to identify their mothers as citizens in order to safe-guard their own status within the community. I here make a slight distinction, with votive offerings attesting to the value of female citizenship to the women themselves, rather than to the men whose status relied on them. Indeed, citizenship was a crucial component of women's independent identities, and a source of social prestige that was increasingly advantageous to promote. The andronymic achieved this by displaying the main criteria of citizenship in the fifth and fourth centuries - descent from two citizen parents. I should note here that naming a citizen husband, rather than a citizen father, still provided evidence of a woman's status, as it meant that she had undergone the scrutiny by her husband's phratry in legitimising her marriage at the Gamelia. The andronymic began to appear regularly at the same time as women's increased representation in grave monuments, not long before the citizenship law of $451 \mathrm{BC}$ that codified citizen women's centrality to the polis. The slight disconnect in chronology, with the uplift in the andronymic beginning in $480 \mathrm{BC}$, several decades before Perikles' law, is not necessarily problematic, given that the law may merely have formalised a pre-existing tendency toward endogamy that began with the advent of democracy. While aristocratic marriages between Athenians and foreigners were

223 See: Sourvinou-Inwood 1995, 116

224 Osborne 1997, passim. 
common in the sixth century, none can be attested from the early fifth, suggesting that Athenians were already beginning to look inward for marriage partners. ${ }^{225}$ The selfconfidence of the Athenians grew over the course of this century as a consequence of their defeat of the Persians and the emergence of the Athenian 'empire,' and as Athens' power and regard for herself rose, so did the value of being an Athenian. This not only explains why Athenian men chose to look inward for a partner, attempting to maintain the value of citizenship by keeping it within the polis, ${ }^{226}$ but also why women were so compelled to identify themselves as citizens at this time. As the value of male citizenship rose, so too did the value of female citizenship. After all, the divergence in how male and female citizens manifested their share in the polis was nothing compared to the growing gulf in status between a person who was Athenian and a person who was not. Even in the fourth century, when the real value of Athenian citizenship was in decline, along with Athens' power and influence over wider Greece, the essential self-conscious distinction between the Athenian and the foreigner remained, as we can see in the court cases that contested citizen status.

As a final note, the primary function of the andronymic as a status symbol and marker of independent female citizenship is supported by similar use of the patronymic by male dedicators on the Acropolis. ${ }^{227}$ Even after the emergence of the demotic after 508 $\mathrm{BC}$, the patronymic never fully disappeared. ${ }^{228}$ It did decline in frequency immediately after the advent of democracy, but it began to re-emerge after $480 \mathrm{BC}$, appearing in conjunction with the demotic, and experienced another surge in popularity after Perikles' reforms. ${ }^{229}$ By the beginning of the fourth century, the Athenian male name settled on a consistent formula, providing both the patronymic and demotic in addition to the personal

\footnotetext{
${ }^{225}$ Eminent sixth-century men with non-Athenian wives: Megakles, Peisistratos and Miltiades (Sealey 1990, 170 n. 4); or, who were the product of mixed marriages: Themistokles, Kleisthenes and Kimon (Rhodes 1981, 332). Osborne (1997, 7) identifies a lack of evidence for foreign marriages after 480 BC, compared to common examples pre- $480 \mathrm{BC}$, as indicating a possible change in marriage patterns. Cf. Kennedy $(2014,18-19)$ who argues for the continuing practice of mixed marriage right up until they were outlawed in the fourth century.

${ }^{226}$ Increased self-regard and "exclusiveness" of Athenians: Osborne 1997, 4-11.

${ }^{227}$ Raubitschek 1949, 476; Winters 1993, 163-4.

228 The Athenaion Politeia (21.4) suggests that the demotic was codified by Kleisthenes at this point. But this is likely incorrect, instead reflecting the demotic's popularity in contemporary fourth century naming practices (Winters 1993, 165; Keesling 1995, 270; Blok 2005, 23).

${ }^{229}$ Raubitschek 1949, 476; Winters 1993, 163 n. 5 and 164. Cf. Whitehead (1986, 71) who acknowledges that the shift to the demotic was not clean, but disagrees that an "intelligible" trend can be determined from early naming patterns.
} 
name. ${ }^{230}$ In my view, this trajectory mirrors women's use of the andronymic rather closely. As noted above, the andronymic does not regularly occur in female offerings before c. $480 \mathrm{BC}$. But after this point, at the same time that the patronymic began to reappear in male offerings, women slowly begin to name male relatives. Then, in the fourth century, when the patronymic was re-established as a formal component of the male name, women also regularly reference a father or husband in the inventory lists. The citizenship law of $451 \mathrm{BC}$ that foregrounded parentage, and the conditions of post-Persian War Athens that encouraged endogamy and increased the value of citizenship, meant that it was in the best interest of all citizens, both male and female, to advertise their status through demonstrating the major pre-requisite: descent from citizen parents. ${ }^{231}$ This parallel between men and women is strengthened by women's use of the demotic. While women did not have their own demotics, they could reference that of a male family member. ${ }^{232}$ It is interesting that both of the pre-480 dedications that include the andronymic also supply the man's demotic. ${ }^{233}$ In comparison, only three out of the eighteen dedications that name a male relative after $480 \mathrm{BC}$ also provide the man's demotic. ${ }^{234}$ Immediately after the advent of democracy, when men were increasingly using the demotic to denote citizen status, women also tended to use the demotic of a male family member to identify themselves. But, later, as the patronymic regained currency with men, and eventually become an essential indicator of citizenship, women tended to reference the andronymic alone. This cross-gender shift towards spotlighting citizen kin - particularly a parent - above formal links to civic institutions reiterates the later emphasis on parentage as the major qualifier for citizenship, thus supporting the andronymic as an articulation of female citizen status. Finally, it is worth noting in passing that men tended to dedicate in their name alone quite frequently in the decades before $480 \mathrm{BC}$, with this dropping off only slightly in the Classical period. ${ }^{235}$ Thus, we

\footnotetext{
${ }^{230}$ For discussion of the patronymic versus the demotic: Raubitschek 1949, 472-6; Winters 1993, 163-4.; Keesling 1995, $269 \mathrm{ff}$.

${ }^{231}$ Raubitschek $(1949,475)$ asserts that Perikles' reforms facilitated the endurance of the patronymic in the male name as a means of denoting citizenship. Reiterated by: Whitehead 1986, 72.

${ }^{232}$ Pomeroy 1995, 118; Blok 2005, 23 n. 83.

${ }^{233}$ Cats. A6 and A9.

${ }^{234}$ Demotic and andronymic: Cats. A29, B7 and B23. Andronymic only: Cats. A25, A27, A30, B2-6, B89, B15-16, B19-20, B23.

${ }^{235}$ Forty-two out of ninety-seven dedications made by men between 510-475 were dedicated under the personal name alone; this number drops slightly between 475-450 (twelve out of thirty-eight), and even further after 450 (Winters 1993, 163-4). Cf. Raubitschek's (1949, 473-4) suggestion that the personal name alone occurred irregularly across all time periods so cannot be used interpretively.
} 
can perhaps see a parallel here with women dedicating by personal name alone at the end of the Archaic period, before one's status as a member of the community was something that needed to be emphasised. I acknowledge that the numbers here are few, so interpretation must be cautious, but given the surrounding evidence, it is plausible to entertain female naming patterns as reflective of male trends, both being increasingly focused on identifying the dedicator as a citizen.

\subsection{Conclusions}

Votive offerings were exceptional in their capacity to act as vehicles of public selfidentification for living women in Archaic and Classical Athens. The religious context, which legitimised women's visibility in the public sphere, and the self-celebrating nature of votive offerings made them the perfect platform from which to advertise one's status. This was reflected in the increased tendency for women to promote their growing value as citizens via the inclusion of the andronymic in the fifth and fourth centuries. Women's interest in promoting themselves was limited by a simultaneous desire to be perceived as adhering to gender ideology. Indeed, the minimising of female dedicators' perceived presence in the sanctuary by dedicating inside Athena's temples, and perhaps also by framing themselves as subordinate to a named male family member, reflects the care with which women needed to navigate the public sphere. Female naming patterns in the Acropolis dedications make clear that Classical Athenian woman aimed for a perception of conspicuous invisibility, rather than a genuine lack of engagement with the public sphere. They would identify themselves as citizens by the inclusion of an andronymic, thus asserting their valued place within the wider community, but would also dull the impact of this expression of personal identity by dedicating within the temple. For all practical purposes, temple offerings would still have been visible to the community, being recorded in the inventory lists and in some instances even utilised during the Panathenaia - but this context allowed them to appear less ostentatiously public. 


\section{Chapter Three: Veiled control over resources}

\subsection{More than just "transmitters of property"}

Just as votive offerings' use of the female personal name and andronymic demonstrates a stronger and more socially valuable public persona for women than ideology would suggest, the mere existence of female dedications reveals another aspect of their hidden agency: women's ability to exert control over property. Women have been viewed as having only "ephemeral" and oblique contact with property, with emphasis placed on women as "transmitters of property" through their ability to convey inherited wealth between men without at any point legally owning the property in their own right. ${ }^{236}$ Also highlighted has been women's indirect access to wealth through their role as managers of household finances, especially during periods when men, the natural leaders of the oikos, were absent; indeed, as Xenophon's Oeconomicus (7.35) suggests, the ideal wife would diligently "receive what comes in and dispense as much of it as must be spent, and watch over as much as is to be kept in reserve, and take care that the amount stored up for a year is not spent in a month." 237 However, the extent of women's independent authority over property has been somewhat obscured by the legal restrictions that limited their formal agency, and the ideological emphasis on men as controllers of property through their role as public economic actors and official owners of oikos property. Direct female control over property is evident in the fact that women were able to dedicate in their own names, sometimes depositing objects of significant value. ${ }^{238}$ I argue that women could, and did, enjoy personal control over significant property, but were required to do so in a way that complied with their prescribed gender role. It is no surprise that women's exclusion from the formal institutions of the public sphere - the phratry, the deme, and so on - also extended to their exclusion from the legal mechanisms used to administer property. But, this did not bar women from engaging with property; rather, appropriate to her ideological role, women's access to resources was typically out of sight, being customary and

\footnotetext{
236 "Ephemeral": Foxhall 2003, 9. "Transmitters of property": Gould 1980, 44-5. Also Harrison 1968, 109.

${ }^{237}$ Kosmopoulou 2001, 283 n. 13; Levick 2012, 100, citing Dem. 50.

${ }^{238}$ As mentioned in Chapter One, I interpret named a female dedicator as indicating direct female agency over the offering. Also, it is worth reiterating that the offerings that survive represent the most expensive, so do not necessarily reflect the quantity of resources available to the average woman.
} 
domestic, or public and commercial but 'off the books. ${ }^{, 239}$ Indeed, religion, which was customary and firmly within women's role, provided an appropriate forum for a woman to conspicuously display the resources which she possessed through votive offerings. ${ }^{240}$ Women seem to have even enjoyed legal control over property when it was in the domestic context of contracts between extended family members, as is the case in Against Spoudias (Dem. 41). Lower-class women - particularly metics and freedwomen, but also poor citizens - routinely engaged in non-customary, non-domestic property transference by working outside the home in order to support themselves and their families. Indeed, although their participation was veiled by avoidance of the formal, public avenues of property transference, votive offerings are indicative of the broader reality of Athenian women as economic agents.

\subsection{Legal restrictions}

First, we must determine the extent to which women could 'own' property. This question is a difficult one, in part because Athenian concepts of ownership were fundamentally nebulous and not always visible in a public context. Further complexity is added by the resources available to a woman, and the way that she may appropriately interact with them, differing depending on her wealth, citizen status and position within her family. However, there were two overarching barriers that frustrated all types of women's engagement with property: firstly, that, whether citizen or non-citizen, a woman had no independent authoritative legal persona, so required the representation of a man - either a kyrios or a prostates - to enter into, or have legal recourse upon the breach of, a contract; and secondly, that her right to dispose of property independently was legally capped at a level that allowed only petty trade. These factors were, of course, founded on and supplemented by the ever-present ideological pressure against women engaging with the public sphere.

\footnotetext{
${ }^{239}$ I am interpreting custom according to Gould's $(1980,46)$ definition, as something that: “embraces roughly the informal patterns of behaviour and the norms and attitudes which are implicit in such behaviour."

${ }^{240}$ While religion was sometimes codified, I feel comfortable referring to it as customary for my purposes because of its inherited nature, being old and slow to adapt (Goff 2004, 22-23).
} 


\subsubsection{Kyrieia}

The legally subordinate ${ }^{241}$ position of even citizen women was founded on them being perpetually under the kyrieia of the men who headed their oikoi - even as they were passed in marriage from their fathers' households to their husbands'. ${ }^{242}$ Being subject to guardianship, women were on the whole unable to legally represent themselves, with Gould going so far as to describe then as "un-person[s]" before the law. ${ }^{243}$ In reality, citizen women were not quite so denigrated as to be legal non-persons - rather, they should be understood as recognised but formally invisible before the law. ${ }^{244}$ Citizen women certainly did engage with legal institutions, although in a more restricted capacity than men: women could not act as witnesses, but they could give evidentiary oaths, speaking to the desire for women's contact with the law to be unseen; they could also attract legal punishment where the penalty was death or slavery (i.e. where it was not monetary); and the law protected from physical harm, although, as Omitowoju posits, discussion of violence against women in the law courts minimises the women themselves, again revealing a desire for female contact with the law to go unseen. ${ }^{245}$ Women's ability to engage with the law in certain circumstances is explicit in Against Spoudias (Dem. 41). This fourth-century court case features multiple women acting as officially recognised legal agents. Firstly, the widow of Polyeuktos is described as having given a loan of 1,800 drachmas from her deceased husband's estate to her son-in-law, Spoudias (Dem. 41.910). Here, the loan is given by the widow in her own right and protected by legally defensible documents. Further, her brothers, who might have been expected to act on her

\footnotetext{
${ }^{241}$ Here I deliberately avoid terms that frame women as "perpetual children" (Sealey 1990, 40-2), "perpetual minors" (Todd 1993, 207) or "permanent minors" (Raaflaub 1998, 32) before the law. Such phrasing, which creates an equivalence between the legal status of women and children, is common among scholars (the above being just a few examples), and has some grounding in Athenian thought (Is. 10.10 and Ar. Pol. 1.1260a9-14 (discussed in Sealey 1990, 40-1)). But, it conceals the extent of women's legal agency, as they could sometimes be recognised as legal authorities whereas children could not (see below).

${ }^{242}$ Although there was an ideal sequence of guardianship (the father or brother, then husband, then, if necessary, son), Schaps $(1979,48-9)$ argues that any relative, or even a male "friend," could act as kyrios if need be. On the complex dynamics of women's movement through different oikoi and kyrieiai see: Cox $1998,86 \mathrm{ff}$.

243 Gould 1980, 45. Similarly, Harrison $(1968,109)$ suggests that an Athenian woman could "never become a full person in her own right," and (Just 1989, 29) that she experienced "complete incompetence before the law."

${ }^{244}$ Sealey 1990, 49.

${ }^{245}$ Summary of legal capacity: Todd 1993, 208. Violence against women in law courts: Omitowoju 2016, passim.
} 
behalf if she were unable to perform the role of legal agent, are described as witnesses rather than kyrioi. ${ }^{246}$ The widow of Polyeuktos was not the only woman to exert legal authority in this case: the wife of the plaintiff also is described as advancing money in order to cover the costs of Polyeuktos' funeral (Dem. 41.11); and Spoudias' wife is represented as having the legal authority to act on behalf of herself and her husband, being alone at the reading of Polyeuktos' will (Dem. 41.17), and to act as a witness by verifying her mother's seals (Dem. 41. 24). It has been argued that this was a domestic issue due to exchange being between family members, and so did not amount to legal authority (the loan being more aligned with gifting practices). ${ }^{247}$ As Cohen notes, the loan is not only described as having been given by the woman, but it was she who possessed the related legal documents, described as being left behind by her at her death, and it is her seal by which they were ratified. ${ }^{248}$ Indeed, the mere fact that the actions of these women were legally authoritative enough to act as evidence in the court setting demonstrates their capacity as legal agents. ${ }^{249}$ Although the private context in which this transaction and surrounding authorisations were conducted was important (perhaps essential) for the appropriateness of these upper-class women's engagement with the law, I follow Cohen in viewing these as reflective of women as unable to overtly represent themselves in nondomestic contexts, but recognised as legal authorities where appropriate. ${ }^{250}$ Although tacitly acknowledged by the law, the need for representation by a kyrios remained a serious handicap that undermined the possibility for complete female autonomy over large-scale transactions, as is demonstrated by a horos for an eranos loan given by a female lender (cited as "horos no. 114A"), laid out by Edward Harris. ${ }^{251}$ This transaction also possibly belongs to a domestic context, with eranos loans typically given to desperate relatives or friends. ${ }^{252}$ However, this female lender enlisted the help of a man, who received the pledge of security, in order to make the loan legally defensible, as she could not herself bring a case against the borrower if he defaulted. ${ }^{253}$ Indeed, as well as

\footnotetext{
246 Cohen 1998, 55-6.

${ }^{247}$ de Ste. Croix 1970, 276.

248 Cohen 1998, 55-6. See also: Harris 1992, 320.

${ }^{249}$ Sealey 1990, 39.

${ }^{250}$ Cohen 1998, 57.

${ }^{251}$ Harris 1992, 310 .

252 Harris 1992, 312.

${ }^{253}$ Harris 1992, 318-9.
} 
demonstrating the legal restrictions placed on women, this horos is a reminder that, in practice, there were many ways for these to be subverted.

Metic women were similarly reliant on the good-will of men when it came to large-scale commerce. On the one hand, a foreign woman in Athens did not need to be constantly in the kyrieia of a man, instead able to be legally recognised as aute autes kuria ("her own kyria") for the purposes of administering the metoikion (metic tax). ${ }^{254}$ This independent legal capacity, which must have occurred in relatively high numbers to warrant the creation of a separate taxation class, ${ }^{255}$ as well as evidence of foreign women's engagement with commerce (such as Neaira in Dem. 59) makes it tempting to view metic women as enjoying more control over resources than citizens. ${ }^{256}$ Indeed, the fact that women could be taxed independently suggests that they were expected to earn money, and had the capacity to do so. ${ }^{257}$ However, Kennedy argues that independent legal status was likely adopted only if circumstances demanded (that is, if a woman were unmarried and had no male relatives in Athens), as metic women ideally fulfilled the same basic gender role as citizens, so should, if possible, be attached to an oikos that could then be taxed as a family unit. ${ }^{258}$ Metoikion rates for a single woman (six drachmas annually) and a man (twelve drachmas annually) were different on the understanding that a man paid for his household, while a woman paid for herself alone. ${ }^{259}$ This demonstrates, as will be reiterated below, that women, when aligned with the oikos, were obscured in the formal records, in this instance amalgamated into her husband's metoikion. Further, like all metics, foreign women had no formal agency in Athenian law, and so required the representation of a male prostates, or Athenian citizen sponsor, to represent them. ${ }^{260}$ Indeed, despite an outward appearance of increased independence through the ability to be one's own master, metic women were in fact more legally vulnerable than citizens, as the law not only did not formally recognise their agency, but did not protect them or respect them as tacit legal authorities as it did for women. ${ }^{261}$ Thus, while foreign women

\footnotetext{
254 Kennedy 2014, 2.

${ }^{255}$ Kennedy 2014, 2.

256 Todd 1993, 209.

${ }^{257}$ Kennedy 2014, 2.

${ }^{258}$ On gender role of metic women: Kennedy 2014, 58.

${ }^{259}$ Kennedy 2014, 2.

${ }^{260}$ Kennedy 2014, 2.

261 On vulnerability of metic women: Kennedy 2014, $97 \mathrm{ff}$.
} 
were perhaps expected to engage with commerce, accumulating the funds necessary to pay their metoikion, both types of women did engage with property, although they were limited in different ways.

\subsubsection{Disposal}

The need for a male legal representative interacts interestingly with a law that limited women's right to alienate property. A passage of Isaios (10.10) states that a woman (or a child) cannot dispose of property above the value of one medimnos of barley. The law is also referenced in Aristophanes' Ecclesiazousae (1024-5), where it is jokingly suggested that kyrioi (rather than women) should not deal in more than one medimnos of barley. ${ }^{262}$ This is not an insignificant amount of capital, estimated as enough to feed a family for just under a week and equating to around three to six drachmas. ${ }^{263}$ Such a limitation, if rigidly enforced, would have excluded women from all but petty trade and the day-to-day transactions required to manage a household. Accordingly, the law has been viewed as permitting only enough freedom to facilitate in practical terms women's domestic role; Schaps in particular sees this law as creating a distinction between small, domestic transactions and an ability to dispose of the "family fortune," which was the exclusive prerogative of the kyrios. ${ }^{264}$ The limit, however, may have had some flexibility. L. J. Kuenen-Janssens suggests that the exact value of the upper limit for female alienation of property is not only difficult for modern scholars to calculate, but would also have been vague and "informal" to the Athenians (as was typical of their approach to law). ${ }^{265}$ Further, there is debate as to whether this limit, though vague, was absolute, or if women could in fact engage in larger transactions provided they had the permission of a kyrios, and also whether permission was needed under this threshold (though this is unlikely). ${ }^{266}$ Despite there being substantially less evidence for high-value disposal by women than by men - or even by women from other periods or parts of Greece - it is evident that, in

\footnotetext{
262 Also mentioned by schol. ad. Ar. Eccl. 1026; Dio Chrys. 74.9.

${ }^{263}$ Value as calculated in: Kuenen-Janssens 1941, 202 ff.; still regularly cited (Schaps 1979, 52; Just 1989, 29; Brock 1994, 341).

264 Schaps 1979, 52.

265 Kuenen-Janssen 1941, 212; supported by Just 1989, 29.

${ }^{266}$ High-value disposal with consent of kyrios: Harrison 1968, 114. Complete inability to dispose of highvalue property: de Ste. Croix 1970, 274-5; Just 1989, 29; Sealey 1990, 37-8; Todd 1993, 208. Against kyrios permission required for small transactions: Schaps 1979, 52; Just 1989, 29; Cohen 1998, 54 n. 6. Brock $(1994,341)$ suggests that even if it were required, in practical terms it would have been "taken for granted most of the time".
} 
some circumstances, female disposal did occur. ${ }^{267}$ For one thing, as the above loans given by Polyeuktos' widow and the woman from horos no. 114A demonstrate, in practice women were disposing of large values of property. Indeed, the loan given in Dem. 41 in particular has been problematic for those who argue against large transactions with kyrios consent, with scholars attempting to frame this as not an act of female disposal. G. E. M. de Ste. Croix suggests that, given the domestic context, it would have been considered more a gift than a legally defensible loan, and Sealey posits that the loan did not come from the widow, with her merely being the practical executor of her husband's estate. ${ }^{268}$ I agree that the domestic context of the loan, in which Polyeuktos' widow extended her natural role as housekeeper to oversee her husband's estate, added legitimacy to her disposal of property. However, it remains evident that her actions were legal in nature and that her independent legal agency was at work. ${ }^{269}$ In addition to legal transactions between family members, there are instances of working women commercially trading in large values (see below for examples). Schaps attempts to negotiate this by arguing that, while no large transaction by a woman - even with kyrios consent - was technically legally valid, if the other party was confident that a woman's kyrios would not intercede, then in practice the transaction went ahead. ${ }^{270} \mathrm{~A}$ lack of formal legal protection for traders is perhaps supported by the need for a male co-signer on horos no. 114A. But, even if tradeswomen technically could not legally engage in commerce, the reality of frequent and high-value disposal, and the absence of evidence for these transactions being challenged, was so far from this official position that it is almost inconsequential. Finally, given my assumption of female agency over offerings from women, expensive, commissioned-for-purpose dedications deposited by women speak for disposal of significant amounts of capital. ${ }^{271}$

Ultimately we must be left with the untidy conclusion that while there is evidence that women were technically not meant to dispose of high values of property, they in practice did - whether this was facilitated by the consent of the kyrios or merely common practice being dissonant with legal fact. Female disposal could have a legal tint, as is the

\footnotetext{
${ }^{267}$ Lack of evidence emphasised particularly by de Ste. Croix 1970, 274-5.

268 De Ste. Croix 1970, 274 and Sealey 1990, 37-8.

${ }^{269}$ Domestic context facilitating legal agency: Cohen 1998, 55-6.

${ }^{270}$ Schaps 1979, 54-5.

${ }^{271}$ Cf. Harris-Cline $(2003,6)$, who views dedications of valuable, non-personal items as facilitated by the kyrios. Also: Sealey 1990, 37.
} 
case in Against Spoudias, so it would not be right to say that it was always extra-legal. But, where it did occur, it was typically legitimised by being domestic (or religious) in nature, or was 'off the books' and likely not defensible in court. As we will see below, this is in line with the customary and domestic nature of women's acquisition of property.

\subsection{Concepts of ownership}

These two restrictions - dependence on a kyrios and formally limited independent disposal - have led some scholars to conclude that women could not formally own "valuable" property, particularly land. ${ }^{272}$ Concepts of ownership are difficult to grasp, as the Athenians rarely wrote about the nature of property directly. A rare and much-cited instance of its articulation can be found in Aristotle's Rhetoric (1361a16-19), where he tangentially mentions ownership while describing the nature of wealth. This has often been taken as an authoritative definition of ownership. ${ }^{273}$ The passage reads:

Wealth consists in abundance of money, ownership of land and properties, and further of movables, cattle, and slaves, remarkable for number, size, and beauty, if they are all secure, liberal, and useful. Property that is productive is more useful, but that which has enjoyment for its object is more liberal. By productive I mean that which is a source of income, by enjoyable that which offers no advantage beyond the use of it - at least, none worth mentioning. Security may be defined as possession of property in such places and on such conditions that the use of it is in our own hands; and ownership as the right of alienation or not, by which I mean giving the property away or selling it. In a word, being wealthy consists rather in use than in possession; for the actualization and use of such things is wealth. ${ }^{274}$

The distinction between possession and ownership, the latter of which required the right of disposal - something that was limited for women - has led some scholars to conclude that women could not legally own property. ${ }^{275}$ Aside from the potential for the aims and nature of the Rhetoric to create a biased view of general ownership, Foxhall argues that Aristotle's discussion of use, as well as disposal, in fact highlights that disposal (which was also customarily limited for men due to the Athenian understanding of oikos property as "held in trust" for the next generation) was in fact only one element of ownership. ${ }^{276}$

\footnotetext{
272 General inability to own "valuable" property: Gould 1980, 44 n. 41; de Ste. Croix 1970, 273-275 and

277. Inability to own land: Schaps 1979, 5; cf. Foxhall 1989, 33.

${ }^{273}$ Harrison 1968, 202; Foxhall 1989, 26-27.

274 Trans: Loeb Classical Library.

275 Gould 1980, 44 n. 41; Foxhall 1989, 26-8; Harrison 1968, 202.

${ }^{276}$ Foxhall 1989, 27-8.
} 
Indeed, Xenophon's Oeconomicus (1.5-11) also phrases ownership in terms of use, rather than merely disposal: "property is that which is useful for supplying a livelihood, and useful things turned out to be all those things that one knows how to use."277 Although the law was disproportionately concerned with disposal, this was not the only test of ownership in the Athenian psyche. Indeed, as in many societies - but especially in Athens where the law was characteristically vague - the lived reality of an individual was not dictated entirely by law. ${ }^{278}$ Harris (among others) has pointed out that a narrow study of the law will never give an accurate picture of Athenian life, and that the law must instead be interpreted holistically by placing it in the context of non-legal evidence:

Laws can only prescribe or proscribe certain actions. They do not describe what life was actually like. Of course, the letter of the law, if rigorously enforced, must be observed. Human beings, however, are always capable of finding devices to enable them to subvert the spirit of the law. ${ }^{279}$

Most significantly, non-codified customary practices, some of which were deeply entrenched in Athenian society, also had an effect on how a person might behave. This is particularly important to understanding the reality of women's lives, something that we have already seen in the matters of guardianship and disposal: while women were formally legally subordinate and unable to engage in large-scale transactions, the reality was very different.

With this in mind, it is clear that not all types of property, or of ownership, were the same in Athens. Particularly, there was a noticeable distinction between individual property, which was often informally associated with an individual through use, and household property, which was at a formal, visible level controlled by the kyrios on behalf of the family unit. The interaction between these two types of property is laid out by Foxhall, who discusses the effect that public and private contexts had on property relationships. She argues that, although special relationships with objects through use might make them understood as 'belonging' to an individual in a domestic context, property was ultimately attached to the household. ${ }^{280}$ Accordingly, the individual

\footnotetext{
277 Trans: Cox 1998, 130.

${ }^{278}$ Greek concepts of ownership as "extremely fluid": Harrison 1968, 52; reiterated by Foxhall 1989, 25.

${ }^{279}$ Harris 1992, 310. Also: Gould 1980, 42 ff.; Foxhall 1989, 25; Cohen1998, 53.

${ }^{280}$ Foxhall 1989, 2, 26 and n. 24 (quoting Ar. Pol. 1.9.3: "property is part of the household"). Cox (1998, 132) also notes property as closely related to the household, with "oikos" in primary sources referring not only to the family members and the physical house, but also household property.
} 
property attachments of subordinate household members were obscured in the public sphere, because the kyrios - the only oikos member who could freely move between the public and private spheres - became the representative of the family group in administering all public transactions involving household property. ${ }^{281}$ Foxhall's interpretation is useful because it does not undercut women's private attachments to items, or suggest that the kyrios was the only family member who could manage communal property - although he was certainly legally and socially empowered to do so with the most directness and ease. As has been mentioned, management of household property was part of women's ideological role, including oversight of shared finances. ${ }^{282}$ Xenophon's Oeconomicus (3.10, 12 and 15) explicitly portrays women as, in ideal circumstances, being partners in management of the household with their husbands. Further, as will be discussed shortly in connection with the dowry (and paid income), the majority of women were not just managers of their husband's resources, but active contributors to communal household wealth. The fact that the dowry remained ideologically attached to the woman, even as it was formally amalgamated with other household wealth and concealed by her husband's public authority, speaks to her having a stake in the economic welfare of the family, an ability to influence how it was utilised. ${ }^{283}$ Indeed, the kyrios ' power, although superior, was in practice likely not absolute; even if not for direct pressure applied by a strong-willed wife, he was morally obliged to care for, and act in the best interests of the free dependents in his household (although this is not to say that he always did). ${ }^{284}$ As Foxhall says, “...in most cases he worked on behalf of his household or in consensus with them - he was not a tyrant." ${ }^{285}$ Indeed, the loan given by Polyeuktos' wife may be seen as an example of women's authority over household finances (although her status as a widow perhaps allowed more control than the average married woman would have). ${ }^{286}$ Thus, while women's ownership may be concealed by her exclusion from the public sphere, this does not mean that property could not be understood as belonging to them.

\footnotetext{
${ }^{281}$ Foxhall 1989, 31.

282 Kosmopoulou 2001, 283 and n. 13.

${ }^{283}$ On women's informal control of communal resources: Cox 1998, 104.

${ }^{284}$ Harrison 1968, 111-2; Just 1989, 28-33.

${ }^{285}$ Foxhall 1989, 31-2 (citing Ar. Pol. (3.4.5)). Also: Harrison 1968, 111-2, Just 1989, 28-9.

${ }^{286}$ On extended authority of widows: Schaps 1979, 56; Todd 1993, 207-10 (citing Hunter 1989, 40-1).
} 
In sum, Athenian concepts of ownership were complex, being vaguely held even for the Athenians themselves. Nevertheless, relationships with property can be understood as underpinned by a series of interwoven and complementary dichotomies: use and disposal; individual and household; private and public; and custom and law. Women were typically associated with the former of each of these pairs, but also had a stake in the latter. Athenians' interaction with property cannot be accessed through a codified definition of legal ownership alone. This is particularly true for female ownership, which was often concealed in a public context due to the assimilation of individual property with the household and women's ideological exclusion from the public sphere, thus requiring the male kyrios to be the public economic actor who undertook large transactions on behalf of the group. This lack of visibility, however, did not exclude women from owning and controlling property; in practice they did so, often in an extra-legal way, but sometimes acting as recognised legal agents within the legitimising domestic context.

\subsection{Means of income and dedications as disposal}

Having established that disposal is not necessary to establish ownership, the remainder of this chapter will nevertheless be concerned with arguing that votive offerings reflect women's capacity to dispose of resources in gender-appropriate circumstances. I do so not in the hopes of meeting the standard of disposal as a prerequisite of control over resources (for women had this by default regardless), but rather in order to give a view of women's economic authority as more extensive than has previously been posited. As mentioned it is undeniable that evidence for female disposal is comparatively scant. But, there is also an unusual disparity between this absence of evidence and the volumes of recorded instances of women acquiring property. This dissonance between input and output of female resources can in part be explained by the amalgamation of a woman's property with that of her household, to then be disposed of on her behalf in the public sphere by her kyrios; for I am convinced by the arguments of Foxhall, and to a lesser extent Schaps, which emphasise the kyrios as the public actor in the transformation of oikos property, resulting in obscured female ownership. ${ }^{287}$ However, given the extent to which women were able to acquire property, I find it unlikely that they would never

${ }^{287}$ Foxhall 1989, passim; Schaps 1979, 48-58. 
dispose of their own resources. Instead, I argue that women's disposal, like every facet of their engagement with public life, was self-consciously invisible, as women conducted their economic business through customary and domestic channels that were appropriate to their gender role - including dedications. Indeed, there were a number of means through which a woman might amass property, some of which were available to all women, and others which relied on belonging to a particular class, either in possessing a certain degree of social prestige or in being so lowly as to warrant (or require) a more relaxed approach to stigmatised behaviour. With each type of income, it is impossible to be sure of the extent to which the capital was owned and utilised by the woman herself, versus absorbed by the economic authority of her kyrios. Certainly, there would have been a significant amount of variation from household to household, not only accounting for the various classes and levels of wealth, but also depending on oikos composition and economic balance between male and female income, and of course the personalities involved. ${ }^{288}$

\subsection{1 'Feminine' property: the dowry and pherne}

The dowry (proix) is perhaps the most significant property attached to a woman. ${ }^{289}$ Although never a formal legal requirement, the dowry was a customary necessity, with its absence being the marker of an illegitimate marriage for citizens. ${ }^{290}$ It provides a pertinent example of the Athenian preference for women's engagement with property to be customary rather than legal, as the dowry is widely accepted as having acted as the daughter's share of the inheritance from her natal oikos (though it was always smaller in value than the inheritance formally allotted to her brothers). ${ }^{291}$ It typically consisted of cash and movable property of some value, such as jewellery, furniture and metal items. ${ }^{292}$ Foxhall argues that women were generally associated with movable, or "invisible," property such as this rather than real estate, although it was not uncommon for the dowry

\footnotetext{
${ }^{288}$ Acknowledging circumstance and personality as factor: Foxhall 2003, 6.

${ }^{289}$ I have opted to exclude property yoked to epikleroi from this discussion; it seems to me too far removed from the woman's immediate authority to suggest she might be able to use it for dedication given that the property was neither within the scope of her formal rights of disposal nor, unlike the dowry, ideologically understood as belonging to her (Todd 1993, 21; cf. Foxhall (2003, 5-6), who argues that the yoked couple in practice used the inheritance before the son came of age).

${ }^{290}$ Foxhall 2003, 8; Kennedy 2014, 98. Cf. Harrison 1968, 48-9.

${ }^{291}$ Harrison 1968, 113; Foxhall 1989, 32 (citing Is. 5.27, where inheritance is posthumously divided among both male and female children, with dowries for the girls); Cox 1998, 117.

${ }^{292}$ Cox 1998, 76.
} 
to be secured against land. ${ }^{293}$ There is debate as to the extent to which the dowry might be considered as belonging to the wife. Several scholars argue that women, as they were incapable of disposing of such valuable property (with the average dowry for an elite family being between thirty to forty minae, with those referenced by the orators ranging between ten and fifty minae), ${ }^{294}$ were not the actual owners of their dowry and did not manage its practical application, which was instead administered by her kyrios. ${ }^{295}$ However, the dowry is sometimes referred to as belonging to the wife in fourth-century legal speeches. ${ }^{296}$ Also, the fact that the dowry went with the woman if the marriage ended suggests that it was understood as more hers than her husband's, regardless of whether it is possible, perhaps even likely, that the kyrios at times, as the public economic actor of the household, utilised a component of his wife's dowry (although it is unclear whether the wife's permission was required in these instances). ${ }^{297}$ This ability to withdraw such a substantial amount of capital from the household funds upon divorce has been seen as ensuring that the wife has economic agency within the household, especially if the dowry is particularly large; ${ }^{298}$ indeed, Foxhall refers to it as “a woman's ultimate act of disposal." 299 The negative impact of a wife choosing to withdraw her dowry is infamously displayed by the failed attempt at divorce by Alkibiades' wife, Hipparete, who was physically carried away from the archon's office by her husband to prevent the loss of her twenty-talent dowry. ${ }^{300}$ Finally, although during day-to-day use the wife's ownership may be obscured by her dowry's amalgamation with general household property, a distinction between the husband's property and the wife's was in some instances preserved. The dowry was likely unable to be confiscated along with the husband's property or counted towards the property thresholds required for the husband's eligibility for certain public offices, and possibly also was unable to be collected against his debts. ${ }^{301}$ Thus, here we

\footnotetext{
${ }^{293}$ Foxhall 2003, 9-10; Foxhall 1989, 33.

${ }^{294}$ Cox 1998, 75; Schaps 1979, 74.

${ }^{295}$ Harrison 1968, 52-54; de Ste. Croix 1970, 275; Schaps 1979, 57 and 74 ff.; Just 1989, 29.

${ }^{296}$ For bibliography see: Harrison 1968, 52 and Foxhall 198938 n. 86 for references.

${ }^{297}$ Belonging to wife: Foxhall 1989, 35 and 2003, 8. Belonging to wife's natal family: Cox 1998, 75. Permission: Harrison 1968, 52.

${ }^{298}$ Fantham et al. 1994, 73; Cox 1998, 69-70; Foxhall 1989, 37; cf. Todd (1993, 210) who is cautious of overemphasising the authority provided by the dowry.

${ }^{299}$ Foxhall 1989, 39; he also emphasises the woman (rather than the male family member who legally represented her when the divorce was registered at the archon's office) as the key agent in the separation, highlighting the agency of the woman.

300 Plut. Alc. 8.1-4. See also Foxhall 1989, 39 and Schaps 1979, 76-7 for cautionary examples of marrying an overly-dowered woman (or epikleros) in literature.

${ }^{301}$ Foxhall 1989, 35-36 and 41-2.
} 
have a substantial source of income for all citizen women, as well as many non-citizens, that was ideologically attached to the female owner, even if her kyrios may at times utilise it; further, it was an asset that gave her economic power within her marriage and sway in how communal resources might be used. As such, it was a potential source for funding dedications.

Along with the dowry a woman brought to the marriage personal items like clothing and jewellery (pherne). These small items, which could be significantly valuable, would also have been understood as belonging to the wife - perhaps even more so than the dowry given their intimate and often exclusive use by the woman. ${ }^{302}$ Despite being conceptually attached to the woman, the kyrios may again have had some control over his wife's pherne, with Schaps emphasising that he could sue his wife for disposing of her personal items without his permission. ${ }^{303}$ Still, the clear ties of ownership between a woman and her pherne possibly allowed for a higher rate of independent disposal, as, in the context of dedication, is suggested by Harris who argues that women tended to deposit personal property, and woven items that they could produce themselves, as they could do so independently, whereas other objects would need to be paid for by their husband or father. ${ }^{304}$ It is true that female agency over small, personal items of property that may have been part of a woman's pherne (or dowry) is reflected in the dedications of the Acropolis, particularly in the inventory items deposited within Athena's temples, but possibly also in the surviving bronze items deposited in the open air. The inventory items are exclusively small, movable items made from valuable materials, with feminine personal items common - jewellery, for example, represented in six of the entries in my catalogue. ${ }^{305}$ Also, one women in the inscription of her open-air offering describes herself as dedicating a himation (presumably deposited in the bronze bowl on which the inscription is written). ${ }^{306}$ So, we can in part agree with Harris that women certainly seem to have had religious agency over their personal items. However, I disagree with her point that women could not utilise other types of property. Firstly, we should be careful not to

\footnotetext{
302 Foxhall 2003, 9.

${ }^{303}$ Schaps 1979, 57. See also: Harrison 1968, 112.

${ }^{304}$ Harris-Cline 2003, passim. Also viewing small items as independently deposited, large items with aide of kyrios: Sealey 1990, 37; Dillon 2002, 14.

${ }^{305}$ Cats. B3, B5, B7, B9, B11, B14.

${ }^{306}$ A26.5.
} 
overstate the connection between women and so-called "raw" offerings - that is, those already owned and used in everyday life (as opposed to "converted" offerings, which were commissioned for purpose) - which were deposited by both sexes. ${ }^{307}$ Further, the large surviving stone monuments deposited in the open air on the Acropolis are unlikely to have been brought with a woman to the marriage and would likely have been commissioned or bought for purpose from an existing selection, which indicates that she must have had control over cash assets. Already discussed is the influence that the dowry itself gave the woman over household finances - this is in addition to the financial power over shared resources granted by her customary role as manager of the oikos. ${ }^{308}$ However, there were other pervasive means by which a woman could acquire non-personal property: work outside the house.

\subsubsection{Paid work and priesthoods}

Various types of women engaged in paid work in Athens. It is true that stigmas associated with labour for both women and men meant that the majority of free female workers were non-citizens. ${ }^{309}$ Indeed, the ideologically un-citizenly nature of work is articulated in Aristotle's Politics (1329a1-6):

The citizens must not live a mechanic or a mercantile life (for such a life is ignoble and inimical to virtue), nor yet must those who are to be citizens in the best state be tillers of the soil (for leisure is needed both for the development of virtue and for active participation in politics). ${ }^{310}$

Further, this ideal of the leisurely citizen was not just philosophical, but had genuine implications in the real world - as we have seen in the questioning of Euxitheos' mother's citizen status due to her engagement in paid work (discussed in Chapter One). However, the example of Euxitheos' mother also shows that citizen women did work and indeed, female citizen workers are attested elsewhere, with Socrates' mother, Phainarete, having worked as a midwife and the plays of Aristophanes in several instances featuring working women. ${ }^{311}$ In order to reconcile this disjunction, the primary sources,

\footnotetext{
$307 \operatorname{Jim} 2014,4$.

${ }^{308}$ Foxhall 1989, 38.

${ }^{309}$ Majority of workforce metics: Kosmopoulou 2001, 283-4; Blundell 1995, 146.

${ }^{310}$ Trans: Loeb Classical Library. For further examples of stigma in literature: Kosmopoulou 2001, $282 \mathrm{n}$. 8; Jim 2014, 174.

${ }^{311}$ Socrates' mother: Pl. Theait. 149a. Aristophanes: Ar. Wasps 238, Thesm. 446-58, and Lys. 463. For discussion of trades undertaken by citizens see: Brock 1994.
} 
and subsequently some modern scholars, suggest that paid work, as something outside of women's ideological role, was avoided where possible and resorted to only during hard times. ${ }^{312}$ However, as Brock points out, the logic of women working only at times of increased social pressure is somewhat flawed. ${ }^{313}$ Firstly, one of the primary sources most often cited as demonstrating that women's labour was a product of necessity, Against Euboulides (Dem. 57.30-1), was motivated by a desire to minimise the ideological stigma attached to paid work, with Euxitheos attempting to attract sympathy from the jury by emphasising that his mother sold ribbons because the family did not "live in the manner we could wish;" indeed, the main interest here is protecting the individual's reputation, not commenting on the nature of work. Further, as Cohen points out, periods of social strain tended to increase social judgements and the interest in limiting civic privileges to legitimate citizens. ${ }^{314}$ Accordingly, women who had an interest in protecting their reputation (particularly their citizen status) might have even more reason, if it were possible, to avoid work during socially difficult periods, rather than to take it up. On a practical note, it also seems unlikely that employers and consumers would be willing to spend more on goods and services during periods of economic recession, meaning that there was no way for a supposed influx of females working to be economically sustainable. ${ }^{315}$ For all but wealthy citizen women, who wore seclusion and unpaid domestic labour as a status symbol, paid work may well have been a common deviation from the often unattainable ideal of the cloistered woman who worked only for the benefit of her own household; this is particularly true for non-citizens who did not need to defend this status by demonstrably citizenly behaviour. While it is possible that difficult times forced some citizen women to expose themselves to potential scrutiny by working outside the house, there would always have been significant numbers of working women in Athens, in good times and bad.

The nature of the stigma attached to working women at least in part reflected the generally un-citizenly nature of paid work, which applied to both men and women. The passage from Politics, for example, stigmatises work for male citizens specifically (for

\footnotetext{
312 Schaps 1979, 19-20; Gould 1980, 48; Kosmopoulou 2001, 284: citing Dem. 57.30 and Ar. Thesm. 446-58.

313 Brock 1994, 344.

314 Cohen 1998, 60-61.

315 Brock 1994, 344.
} 
women would not have been imagined to engage in politics), and the law cited in Against Euboulides (Dem. 57.30), which protects against citizens being ridiculed for trading in the agora, makes no distinction between the degradation attached to male versus female tradespeople. ${ }^{316}$ Rejecting the domestic ideal to work outside the home certainly did also impact public perception of women who worked outside the home, as is demonstrated by Kennedy's discussion of paid work often being conflated with prostitution for metics. ${ }^{317}$ However, this divergence from private life was mitigated by women engaging in trades related to their ideological role as mothers, wives, and unpaid domestic labourers; this translated into female nurses or wet-nurses (the most common profession attributed to working women in Classical Athenian grave-markers), ${ }^{318}$ midwives, ${ }^{319}$ wool-workers, ${ }^{320}$ and traders of domestic products that women could produce themselves, such as bread or ribbons. ${ }^{321}$ Much has been written of the sexual labour of women in Athens, and this was of course also a source of income available to women, although certainly carrying more social stigma than other trades. ${ }^{322}$ But much of the work in which even socially disadvantaged women engaged was non-sexual and did not require the total abandonment of 'respectability.' 323 As Brock and Angeliki Kosmopoulou have pointed out, the archaeological record, particularly tombstones and votive offerings, reveals a degree of social prestige for female workers through monuments that celebrate and identify working women in terms of their profession; indeed, below I discuss several instances of female dedicators naming, even overtly celebrating their professions. ${ }^{324}$ Further, female work was not only in practice common and socially permissible (though still ideologically disparaged), but it could also be lucrative. The disposal limit of a medimnos of barley has prompted scholars to comment that female trade would have been limited to only "small

\footnotetext{
316 Cohen 1998, 59. Against validity of law: Brock 1994, 344 n. 46.

${ }^{317}$ Kennedy 2014, 123 ff.

${ }^{318}$ Kosmopoulou 2001, 285. It is possible that nurses appear most frequently not because they existed in the highest numbers (though they certainly were prolific), but because of the affectionate and often lasting relationship between nurse (who was usually a metic or slave, although sometime a citizen) and child, who would then feel compelled to erect the funerary monument (Kosmopoulou 2001, 285 ff; Brock 1994, 336-7).

${ }^{319}$ Kosmopoulou 2001, 299 ff; Brock 1994, 340.

${ }^{320}$ Kosmopoulou 2001, 300 ff; Brock 1994, 338; Acton 2014, 151 ff.

${ }^{321}$ Brock 1994, 28-9.

${ }^{322}$ Sex work, performing arts (such as music), and physical labour comprised the most stigmatised professions; only the lowest classes of women (i.e. non-citizens) would participate in these trades (Brock 1994, 344).

${ }^{323}$ Emphasised by Kennedy 2014, 123 ff.

${ }^{324}$ Kosmopoulou 2001; Brock 1994.
} 
scale" enterprises and "the most trifling" of transactions. ${ }^{325}$ While this would have been true in some cases - especially given that the stigmatised nature of labour caused many workers to be non-citizen or poor - we should be careful not to underestimate the extent of working women's economic agency. In reality, female income was far from negligible, and evidently had the capacity to exceed the one medimnos limit. Textile production, in particular, was a profitable industry for women who produced luxury woven goods. ${ }^{326}$ For example, Schaps points out that a female cloak-seller, identified by her profession on a tombstone, would have been able to sell her wares for significant sums of money - up to twenty drachmas according to Aristophanes' Wealth (982-3), although this may be exaggerated. To put the scale of this price into perspective, a soldier was usually paid one drachma a day, and workers on the Erechtheion - some of them skilled workers rather than general labourers - made between one and two and a half drachmas a day. ${ }^{327}$ There is also evidence of substantial profits for other types of female traders, with seventy drachmas worth of reeds, recorded in an inscription from the sanctuary of Demeter and Kore at Eleusis as acquired in the course of renovating the site, being sold by a woman Artemis of Piraeus. ${ }^{328}$ Further, the quality of some dedications reiterates the possibility that substantial income was accrued by female workers. For example, the marble basin a large offering from expensive material - deposited by the washerwoman Smikythe as a tithe from her income reflects the extent of female earnings. ${ }^{329}$ To give an indication of cost, an uninscribed marble slab cost between eleven and twenty-three drachmas in the fourth century, and a marble funerary monument cost between ten and twenty drachmas in the same period. ${ }^{330}$ Although it has been suggested that this offering represents the culmination of income received over many years of work, a marble offering like this would still have been a significant investment if Smikythe were genuinely poor and limited to only "the most trifling" means of income. ${ }^{331}$ What is more, three offerings from

\footnotetext{
${ }^{325}$ Sealey 1990, 37; Harrison 1968, 208.

${ }^{326}$ Schaps 1979, 52 and 137 n. 32, citing $I G$ II $^{2}$ 11254. Also on lucrative nature of textile industry: Jim 2014, 172 (citing Vickers 1985, 125 n. 162). Acton $(2014,155-6)$ argues that, contrary to ideology, which dictated that clothing should be produced by unpaid domestic labour, mundane textiles were likely also sold regularly due to an inability for women of oikos to always be "self-sufficient" in meeting clothing needs of the household.

327 Scheidel 2005, 12.

${ }^{328}$ IG II ${ }^{2}$ 1672, line 64, cited by Schaps 1979, 52; Clinton 2005-2008, I.198, II.203.

${ }^{329}$ For discussion of Smikythe as menial worker dedicating valuable item see: Jim 2014, 171-5.

330 Jim 2014, 173 n 132 (citing Nolan 1981, 57-9 and Neilsen et al. 1989).

${ }^{331}$ Representing years of work: Raubitschek 1949, 262; Jim 2014, 172.
} 
the same period name the dedicator as Smikythe, with two of these explicitly labelled as dekatai. ${ }^{332}$ If these were the same washerwoman, then Smikythe's income certainly must have been substantial to warrant multiple expensive offerings - two made from marble and one from bronze.

It is difficult to say whether women retained control over their (sometimes significant) commercial earnings, or if they were to some extent absorbed into general oikos property and then utilised by the kyrios. ${ }^{333}$ Of the known female dedicators of the Acropolis, only two menial workers explicitly adopt their profession as an identifier: Phrygia, a bread-seller and Smikythe, a washerwoman. ${ }^{334}$ The fact that Smikythe identifies her offering as a dekate indicates her agency over her income, as the offering represented a tenth of her income. While Phrygia does not implicitly label her offering as coming from her income, this can perhaps be inferred from the naming of her profession. ${ }^{335}$ A third dedicator, Melinna, is not specific about the type of work she engaged in, but emphasises herself as the key economic actor of her family, with her inscription reading: 336

Melinna, who brought up her family of children by her handicraft and skill

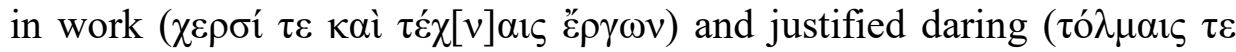
$\delta 1 \kappa \alpha i$ aıs), dedicated to you, Goddess of Works, this memorial of her labours, making a first-offering of a portion of her property, honouring your favour to her. ${ }^{337}$

Melinna's offering dates to right at the end of the Classical period, so may look forward to the increased economic and religious agency of Hellenistic women and should be applied to early- and mid-Classical contexts with caution. This is, however, the most explicit evidence for female agency over income. Melinna celebrates her skill and industriousness, framing herself not only as a worker, but as a businesswoman who makes her own economic decisions - that is, using her "justified daring"; further, she tells us how she used her income to provide for her family. Finally, a fourth dedication, by a

\footnotetext{
${ }^{332}$ Cats. A17-18 and A25.5.

${ }^{333}$ Harris-Cline 2003, 2.

${ }^{334}$ Cats. A8 and A18. I say "menial workers" here to differentiate from the other named 'profession' of priestess which is cited by two women in the inventory inscriptions (Cats. B23 and B25); see below for discussion of priesthoods as 'work'.

${ }^{335}$ See below for more on first-offerings as indicating female agency.

${ }^{336}$ Although not explicitly stated, Melinna's trade was almost certainly handicraft-related, due to dedication to Athena Ergane and explicit celebration of "handicraft" (Jim 2014, 139).

${ }^{337}$ Cat. A31.
} 
woman whose name is mostly lost, does not name her profession and alludes to her saleable skills only in a vague sense, but does celebrate workmanship generally:

It is good for the skilled to exercise their skill in accordance with their craft; for he who has a craft has a better life. [---]e dedicated a dekate to Athena. ${ }^{338}$

This lauding of professional skill, along with the labelling of the offering as a tithe, suggests that the dedicator was herself an artisan. Further, it suggests that the stigma against paid work was not absolute, with work able to be a point of pride for some individuals of all periods (that is, not just in the Hellenistic-facing period of Melinna's explicit self-praise); for these women, their work was a point of pride and a key component of their identity.

While the above workers clearly had the ability to dispose of their income in the form of votive offerings, it is difficult to say whether their class facilitated such financial agency - with, as mentioned above, metics generally being considered to have had greater public economic freedom than citizen women. Phrygia was almost certainly a metic, given that she is named by her ethnic - "The Phrygian." 339 It might also be reasonable to speculate that Melinna was a metic living and working aute autes kuria, as we would perhaps expect that neither a metic with a living male relative, nor a citizen who legally must always have had a kyrios, would shirk her gender role so strongly as to publicly figure herself as the primary contributor to her oikos. ${ }^{340}$ Indeed, the use of aorist here indicates that this offering may have been deposited at the end of Melinna's career, suggesting a long period of her acting as the primary bread-winner for her household. ${ }^{341}$ But we cannot be certain. Similarly, the citizen status of Smikythe and the unnamed women are impossible to decipher. Although there are no proven citizens among the female workers of the Acropolis dedications, given that citizens could work in Athens, it is very possible - likely, even - that some offerings from working women did come from lower-class citizens.

\footnotetext{
${ }^{338}$ Cat. A7.

${ }^{339}$ Dillon 2002, 17.

${ }^{340}$ Kennedy 2014, 26 ff.

${ }^{341} \operatorname{Jim} 2014,139$.
} 
As a final note before moving on to first-offerings, while elite citizens with adequate means likely opted to adhere to ideology and avoid paid work, even they had the potential to receive remuneration for services provided, specifically in the context of religion. The Priestess of Athena Nike received for her service a salary of fifty drachmas in addition to the hides of sacrificed animals, and one obol was supposedly given to the priestess of Athena Polias for every birth or death in Athens (Aristotle Oikonomika 2.2.4.1347a). ${ }^{342}$ Other priestesses are recorded as sometimes receiving meat, wheat, honey, oil, firewood. ${ }^{343}$ Priestly service did not technically constitute a 'profession' in Athens, with appointments typically part-time or temporary, and the role itself was not stigmatised, but was prestigious and citizenly in nature; indeed, priesthoods were ideologically aligned with the other services to the state that Aristotle in the passage above - in contrast to menial labour - deems as fit for citizens. ${ }^{344}$ The distinction between religious roles and other paid work is evident in some priesthoods, which rather than providing income, incurred costs to the individual - such as the need to supply sacrificial animals and food for feasts, or pay for the upkeep of the sanctuary. ${ }^{345}$ Nevertheless, religion provided a means through which even elite citizen women could provide a public service and (sometimes) receive material compensation, cash or otherwise, beyond the domestic property provided by the dowry or pherne (and also gave women a sort of 'professional identity,' as is evident in funerary monuments that identify the deceased by her religious role). ${ }^{346}$

Again, it is difficult to be certain of the extent to which this capital amassed through priestly service was then able to be utilised by the woman. In the temple inventories of the Acropolis two women identify themselves as priestesses: Phanostrate and a second woman whose name is mostly lost. ${ }^{347}$ Similar to the naming of professions by Phrygia and Smikythe, this could allow us to interpret the offering as related to the role, with the dedications in this case deposited to commemorate the tenure of these women's priestly office. However, while dedications that name other professions were

\footnotetext{
${ }^{342}$ Athena Nike: $I G \mathrm{I}^{2} 24$. Athena Polias: Goff 2004, 66.

${ }^{343}$ Other remuneration: Harris-Cline 2003, 2.

${ }^{344}$ Kosmopoulou 2001, 292. Connelly 2007, 17-18 and 29.

${ }^{345}$ Connelly 2007, 167.

${ }^{346}$ Kosmopoulou 2001, 292 ff.

${ }^{347}$ Cats. B23 and B25.
} 
likely paid for by the income from that work, celebration of priestly office served an honorific function that does not directly correlate to the offering having been paid for out of remuneration for priestly service. ${ }^{348}$ The prestigious nature of such income could at the very least be speculated as having, in some circumstances, afforded the woman authority over how it was utilised, similar to the authority over household income given by a substantial dowry - but this is uncertain. Regardless of their domestic control of the resources gained through priesthoods, in the context of their service these women would have publicly managed substantial resources, with practical requirements of festivals and the operation of the sanctuary falling to them. ${ }^{349}$ The individual responsibility placed on female religious leaders is clear in penalties placed on those who were careless in their use of cult funds. ${ }^{350}$ Accordingly, while religion was a special arena that allowed overt participation in activities usually unavailable to women, I would argue that women's competency in this field allows us to infer that the individuals who took up priesthoods were already generally able in the tasks involved; ${ }^{351}$ that is, the large-scale, public management of resources by priestesses in the context of a sanctuary may be seen as an extension of the skills acquired through her role as overseer of her own oikos. After all, religious roles tended to mirror and complement women's lives, ideologically reinforcing their prescribed role. ${ }^{352}$ This is particularly true given that women destined for priesthoods typically belonged to elite families, so the practical skills required for religious service would realistically have been considered during her upbringing. Indeed, Connelly points out that no special training was provided before a girl or woman took up a religious role, with her rather having been prepared throughout her daily life. ${ }^{353}$ Further, the skills required to run a household were ideologically linked to civic responsibilities, such as religious service, in Athenian thought; as Harris says: "The polis and oikos can be seen as parallel worlds, differing only in scale." 354 Thus, we might imagine that even

\footnotetext{
${ }^{348}$ On honorific priestess dedications (mostly Hellenistic): Connelly 2007, 117.

${ }^{349}$ Harris-Cline 2003, 2. All-female festivals also offered opportunities for management, with demewomen electing female officials to oversee the Thesmophoria (Whitehead 1986, 80, citing Is. 8.19-20). ${ }^{350} I G \mathrm{II}^{2}$ 1328; note that this decree is Hellenistic, so should be applied to earlier contexts with some caution.

${ }^{351}$ Although the above decree of punishment for incompetence would suggest not always.

352 Connelly 2007, 30.

${ }^{353}$ Connelly 2007, 29.

${ }^{354}$ Harris-Cline 2003, 3, citing Pl. Pol. 259b-c: "One science covers all these spheres, be it called royal science, political science, or household management: economics."; and Aristotle's suggestion in Ethics $\mathrm{V}$ and Politics I that the polis is modelled on the oikos.
} 
elite women were practiced in procurement and disposal of the sort that would allow them to have agency over their own offerings.

Thus, non-domestic income was available to all types of women - either remuneration for priestly service for the elite or, more commonly, paid work outside of the home for foreigners and non-elite citizens. We have already touched on these roles as indicating female agency over dedications, with the overt naming of professions, general lauding of work, prestigious nature of priesthood, and the founding of religious roles on pre-existing economic capacity indicating that women had the means and ability to fund their own dedication. However, the strongest indicator of direct conversion of female income into votive offerings is the items that explicitly describe themselves as firstofferings.

\subsubsection{Paid work continued: first-offerings}

As mentioned, both Melinna and Smikythe label their offerings as tithes or 'first-fruits' aparchai or dekatai - indicating that their offerings are direct portions of the income that they receive from work. While there are few examples of women who explicitly identify themselves as professionals, the terms aparche and dekate are common among the inscriptions of the surviving open-air items, appearing eighteen times in total out of thirtyeight offerings. ${ }^{355}$ The terms do not appear in the temple inventories, although, as discussed below, this does not necessarily mean that none of these items were intended to be first-offerings. The ubiquity of these labels of aparche and dekate reveal the high numbers of working women who exercised agency over their income, which they personally utilised, and demonstrated their religious obligations over, by dedicating a tithe or first-offerings.

Jim identifies the key features of dekatai and aparchai, which distinguish them from other offerings, as being that they are always: 1) retrospective in nature, so would be given after the motivating event rather than "in anticipation of divine favour"; and 2) prompted by good fortune or a successful enterprise, as opposed to deliverance of danger or misfortune. ${ }^{356}$ This is in addition to the label denoting that the offering was the portion

\footnotetext{
${ }^{355}$ Cats. A2, A7, A9-12, A15, A18-20, A22-3, A25-26.5, A28, A31.

$356 \operatorname{Jim} 2014,2$.
} 
owed to the god from a greater whole of material wealth otherwise enjoyed by the dedicator. ${ }^{357}$ The obligatory (though still ad hoc) process of providing first-offerings was predicated on mortals' indebtedness to the gods for providing the conditions that supported income, or facilitating the particular event that caused a windfall; but firstofferings also reflected gratitude on the part of the dedicant. ${ }^{358}$ The terms aparche and dekate are slightly different in their technical meaning. The former is a 'first-fruits' of any size, whereas the latter is a tithe - literally meaning a tenth - so indicates that the god is owed this particular fraction of the wealth in question. ${ }^{359}$ Indeed, labelling an item as a dekate, where the size of the portion given is clear, has been seen as emphasising the magnitude of the offering more than an aparche does. ${ }^{360}$ Alternatively, the element of the offering being a preliminary share set aside for the god is more emphasised in the term

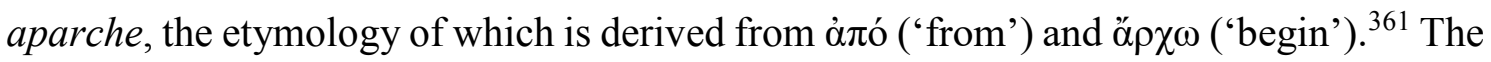
term aparche is found almost exclusively on dedications from the Athenian Acropolis and is always used in a religious context, whereas dekate is attested all over Greece and can be used secularly. ${ }^{362}$ The two terms are, however, roughly synonymous; in practice, a dekate did not always comprise exactly one tenth of income, and an aparche could be made temporally either before or after humans enjoyed their share. ${ }^{363}$ In addition to the lack of clarity in the use of the terms themselves, the difficulty of interpreting firstofferings is exacerbated by the likelihood that there would have been many offerings that were deposited in the spirit of dekatai or aparchai, but cannot be identified as such due to the lack of an inscription explicitly labelling them so. ${ }^{364}$ But, even then, the evidence

\footnotetext{
$357 \operatorname{Jim} 2014,18$.

${ }^{358}$ Ad hoc: Jim 2014, 165. Obligation, indebtedness, and gratitude see: Jim 2014, 68-82. Jim emphasises gratitude in particular, which, along with other element of personal belief, she sees most scholars as unduly minimising in favour of unemotional cause-and-effect ritual.

359 The fact that strict application of the terms aparche and dekate resulted in offerings of differing sizes is demonstrated in a single dedication comprised of two korai (DAA 292). The inscription indicates that one statue is an aparche while the other is a dekate $\left(I G \mathrm{I}^{3}\right.$ 644). Jim $(2014,53)$, following Keesling $(2003$, $9-10,106)$, suggests that the larger is the dekate, and smaller the aparche.

${ }^{360}$ Kaltsas and Shapiro 2008, 60.

361 Jim 2014, 36.

${ }^{362}$ Locality: Ridgway 1987, 402 n. 13; Jim 2014, 23-24. Secular and non-secular: Jim 2014, 52.

Additionally, although not relevant to women's dedications, the term dekate could be applied to military offerings, whereas aparche could not (Ridgway 1987, 402 n. 13; Jim 2014, 52).

${ }^{363} \mathrm{Jim} 2014,14,19$, and 53-54.

$364 \operatorname{Jim} 2014,17-18$, and 167-8.
} 
is substantial, with a third of all offerings from Attica in the fifth century (by both male and female dedicators) being first-offerings. ${ }^{365}$

For women in particular, the terms aparche and dekate are connected to income from paid work. While first-offerings did not strictly need to be in response to labour, in practice they usually were. In a gender neutral context, scholars tend not to equate the first-offerings narrowly with paid work, with Jim describing them as response to a "some success or benefit," Keesling as from "one's wealth or profits," and Parker as from "earnings of various kinds," including a "windfall." 366 Such vague approaches to the aparchai and dekatai are appropriate for men, who had a much broader range of means for acquiring property - and thus of reasons to give thanks - than women did. Indeed, a man might feel compelled to provide the god with their portion from a successful harvest, voyage, hunt, or military campaign ${ }^{367}$ However, the concept of first-offerings does not fit well with the non-commercial ways that women could independently acquire property - namely through the dowry or pherne. ${ }^{368}$ Jim notes that paid work is not always explicit in first-offerings, and that some tithes are rather generally described as coming from one's

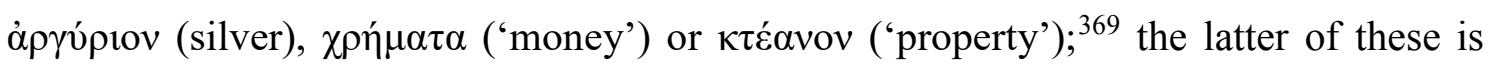
attested in my catalogue, with Thotime describing her aparche as derived from her $\kappa \tau \varepsilon ́ \alpha v o v .{ }^{370}$ This, of course, leaves open the possibility that women sometimes dedicated a portion of their domestic wealth. But this seems to me unlikely, as I am aware of no positive evidence that suggests Athenian women were in practice obliged to dedicate a portion of the dowry that they received upon marriage. As Keesling notes, Herodotus (1.92.1-4) describes offerings given by Croesus of Lydia at Delphi as "the first fruits of his own substance and of his inheritance." Although the dowry is the female equivalent of inheritance, this context of foreign dedication in a Panhellenic sanctuary outside of Attica is too far removed from the present one to be forceful as evidence - quite besides

\footnotetext{
$365 \operatorname{Jim} 2014,131$.

366 Jim 2014, 2; Parker in Boardman et al. 2004, 279. Keesling 2003, 6-10. Cf. van Straten (1981, 92) who in a gender-neutral context discusses dekatai and aparchai under the heading of "work" as the occasion for offering.

367 Boardman et al. 2004, 279; Jim 2014, 149.

${ }^{368}$ Non-property-related reasons for which women dedicate first-offerings later included a dekate upon manumission or aparche as a cult payment (Jim 2014, 151-2. and $251 \mathrm{ff}$.). These circumstances are however specific, identifiable, and not pertaining to income.

$369 \operatorname{Jim} 2014,149-50$.

${ }^{370}$ Cat. A11. Note: the term $\kappa \tau \varepsilon \dot{\varepsilon v o v}$ is reconstructed in this inscription.
} 
the fact that analogy between offerings from male and female modes of inheritance is not absolute. What is more, the pherne almost certainly could not be considered within the circumstances that prompted a first-offering (good fortune, successful enterprise, or windfall) given that it consisted of items already belonging to the woman in her father's oikos. Indeed, in a specifically female context, scholars do tend to view first-offerings as coloured by associations with work. Brunilde Ridgway in her article "Ancient Greek Women and Art: The Material Evidence" describes them as portions of "personal earnings," and Dillon in the glossary of his book on women in religion defines "dekate" as: "“a tenth', usually of proceeds from craftwork or other business, dedicated to a deity." ${ }^{371}$ Finally, it is more likely that Thotime merely used the general term $\kappa \tau \varepsilon \dot{\varepsilon} \alpha v o v$ to reference wealth that she had accrued through paid work (or priestly service) due to the fact that there is positive evidence for first-offerings as associated with work.

Three of the four catalogue items discussed above as explicitly referencing work also described their dedications as first-offerings: Smikythe names her profession on her dekate, the unknown woman uses hers to generally laud the virtues of work, and Melinna's aparche celebrates her labour having allowed her to raise her children. ${ }^{372}$ Further, notwithstanding the fact that citizens did work outside the home if necessary, the association of first-offerings with paid work is supported by this type of dedication generally being attributed to dedicators who were more likely to be metics, and thus belonging to the demographic that was most represented in Athens' paid work-force. Indeed, only one of the Acropolis dedicators who indicates that they were a citizen by including the demotic - the most certain indicator of citizenship - also labels their offering as a dekate. ${ }^{373}$ Even then, this example is dubious as, due to the incomplete nature of the inscription, the gender of the dedicator is not beyond doubt. ${ }^{374}$ Further, this argument is somewhat precarious given the small pool of open-air female dedicators who include the demotic in the first place. ${ }^{375}$ But even if we lower the bar to make the andronymic, which has been established as a marker of citizenship, the test of a citizen women, this adds only one more dedicator to the pool of likely citizens whose dedications

\footnotetext{
${ }^{371}$ Ridgway 1987, 402 n. 13; Dillon 2002, 369.

${ }^{372}$ Cats. A7, A18 and A31.

${ }^{373}$ Cat. A9.

374 Raubitschek 1949, 226-7.

375 Cats. A6, A9 and A29.
} 
are marked as first-offerings. ${ }^{376}$ Thus, with women who mark themselves as citizens unlikely to dedicate dekatai or aparchai, this type of offering is most often deposited by dedicators who do not name a male family member, so are more likely to be foreign and thus working class. This trend is vague, given that some women who exclude the patronymic were likely citizens, and that workers could be either citizen or non-citizen; still, it is a discernible pattern, and one worth noting - especially in the context of positive evidence associating first-offerings with female work. In light of the flexibility of the terms aparche and dekate, and the fact that first-offerings were ad hoc and self-motivated, it is possible that the words were sometimes applied to dedications in connection with non-commercial wealth. But, given the more restricted (and socially scrutinised) nature of female property, there is no evidence to suggest that first-offerings of non-commercial property were the norm for women.

Women overtly referencing paid work or identifying an object as a first-offering appear consistently throughout the surviving offerings, the first appearing in c. 525-10 $\mathrm{BC}$ and the last after $350 \mathrm{BC} .{ }^{377}$ However, the discussion of aparchai and dekatai has so far been limited to the surviving offerings. Indeed, whereas the trend towards inclusion of the andronymic is consistent between surviving and inventory items, there is a sharp disjunction between the surviving offerings and inventories in terms of work. The first possible reason for this could have been a shift in ideology, with the surviving items occupying an earlier period than the inventories. Stigmas against work permeated Athenian ideology since the Archaic period, but the pressure to act in a citizenly way not to engage in labour and, for a woman, generally not to engage with the public sphere - increased throughout the fifth and fourth centuries. ${ }^{378}$ Thus, the greater need for women to appear domestic and invisible in the Classical period may have prompted workers to avoid indicators of their labour. Indeed, this was a precarious time for workers, with working citizens like Euxitheos' mother needing to have their status defended in the law courts (Dem. 57.30-36), and metics, who represented the majority of workers, being at their most socially marginalised (as is reflected in the outlawing of mixed marriages). ${ }^{379}$ This would be a convincing argument were it not for the fact that female workers

\footnotetext{
${ }^{376}$ Cat. A25.

377 Cats. A2 and A31.

${ }^{378}$ Kosmopoulou 2001, 284.

${ }^{379}$ Kennedy 2014, 97 ff.
} 
continued to otherwise be identified and celebrated in archaeological sources. The case for Melinna's offering, which was contemporaneous with the inventory lists, shows us that at least some women in Athens continued to publicise and celebrate their working status in votive offerings. ${ }^{380}$ Further, there are abundant examples of fourth-century grave-markers that identify women by their professions. ${ }^{381}$ While social pressure possibly did have an effect, I see it as more likely that the difference in context between the surviving items and inventories caused workers to be under-represented. The elite nature of the inventory items may well have meant that menial workers - even those who clearly made a substantial living, such as Smikythe - were excluded from the socially elite practice of depositing rich offerings inside Athena's temples. Indeed, the only type of offering that might be analogous with first-offerings from paid work are those from the elite 'profession' of the priestess. ${ }^{382}$ Additionally, it is possible that some dedications recorded in the inventories were deposited as aparchai or dekatai, but either the dedicator did not label it as such in the inscription, or, they did, but this information was not carried over into the inventory list. The potential for information included on the object to later be omitted has already been discussed in reference to the andronymic. ${ }^{383}$ Indeed, having served in an honorific office is within the scope of known motivators for aparchai in Attica - yet, the two self-identified priestesses in the inventories do not label their offering as such. ${ }^{384}$ It could be speculated that these were instances of the function of offerings being left undisclosed or lost during transcription, tentatively opening the possibility that more inventory items are actually unidentified aparchai or dekatai from other nondomestic means of income. However, this perhaps stretches the evidence too far.

In sum, the full extent of paid work for women is demonstrated in their frequent use of the terms aparche and dekate to label offerings as the portion of their income owed to the god. Indeed, this type of offering strongly implies agency over income from paid work. For one thing, it figures the woman as responsible for discharging the religious responsibilities attached to work - that is, ensuring that the gods had their share. Also, it acts as an example of the women disposing of their own income, as they converted it to

\footnotetext{
${ }^{380}$ Cat. A31.

${ }^{381}$ For examples see the catalogue in Kosmopoulou (2001, 306 ff.).

382 Cats. B23 and B25.

383 See Chapter Two.

384 Jim 2014, 150-1.
} 
offerings to dedicate in their own name. Although first-offerings from women disappear during the mid- and late-Classical periods, this was primarily due to the nature of the inventory lists, which were skewed towards the elite so unlikely to include ideologically stigmatised workers. The practical continuation of aparchai and dekatai is supported by the consistent representation of workers outside of the inventory lists in the fourth century, despite the increased stigma and social scrutiny at this time.

\subsection{Conclusions}

With all types of property attached to women there remains the unanswerable question of the extent to which the wealth she acquired was then hers to use as she pleased, or whether it reverted to her kyrios, who, as the public economic actor of the household, possessed superior abilities as to the practical use of household income. Women's access to property certainly was restricted, both ideologically by her exclusion from the public sphere, and legally by her legally subordinate position and capped formal means of disposal. However, the volume of evidence demonstrating the various ways that women could attract property, and the high values of wealth involved in some of these methods particularly the dowry, but also the fruitful nature of certain commercial enterprises speak for women's ability to own and control property. And, indeed, all classes of women could do this. For elite women, the domestic context provided a legitimate forum for recognised legal agency (especially, perhaps, for widows). Further, the customarily female role of household manager, and the sway that women had over household property due to their contribution through the dowry, meant that even elite women would likely have had some control over household resources (although, the extent would depend on personality and circumstances). For non-elite women, both citizen and non-citizen, paid work was a consistent reality of life and substantial source of income which, at least in some cases, would have been administered by the woman herself - as the example of Melinna explicitly shows. In my view, female disposal by gender-appropriate (and thus typically, though not always, extra-legal) means is the invisible reality that balances the scales that, if we take law and ideological biases as the complete picture, are illogically tipped by the large volumes of female income that we can see in the sources. Votive offerings, being firmly within the ambit of women's ideological role, thus provided an 
appropriate means for women not only to exert practical control over their resources, but, due to the duel function of dedication, to display their wealth to the wider community. 


\section{Conclusion}

As this thesis has demonstrated, the position of ancient Athenian women was a complicated one. In order to access the actual lives of women we must not only navigate the nebulous construction of class, in which women might behave differently according to a complex matrix of factors, but also negotiate the interplay between ideology and reality, as women attempted to exercise their agency and assert their value while still appearing to be good examples of their sex. This is in addition to the scarcity of sources and historic issues involved with studying women.

The difficult nature of class is evident in the different focuses of my second and third chapters. The second was concerned with citizen women and their interest in articulating their social value by the public advertisement of citizenship via the andronymic. While not all citizen women were wealthy and elite, this demonstrates citizenship as a divider in Athenian thought and a source of value for those who possessed it. The third chapter, while it included instances of access to property for all types of women, spotlighted non-elites in their connection to paid work. While the majority of the female workforce was foreign, all types of free women - both non-citizens and citizens (apart from those who had the means or social capital to fulfil the ideal of physical seclusion) - routinely engaged in paid work. The different ways that various women interacted with property shows class as a dividing factor for female behaviour. Even elite women who might not degrade themselves by engaging in paid work were able to exercise control over property through domestic and customary means; a family context allowed for legally recognised female authority over resources, inheritance could be received customarily through the dowry and accordingly add more influence to women's natural role as financial managers of oikos property, and the legitimising forum of religion allowed for extensive control of resources through priesthoods and the deposition of expensive offerings in sanctuaries. Non-elite women, in addition to these inherently feminine avenues for property management, were able to engage in paid labour that was technically extra-legal, but nevertheless was socially validated and could represent significant financial value. Indeed, these non-elite working women were unabashed regarding their engagement with the public sphere through labour, in multiple instances overtly celebrating themselves as workers. This demonstrates not only that paid work, even for women, must in practice not have been as stigmatised as ideological sources 
make it seem, but also that non-elite women were perhaps not so concerned with entirely eliminating their invisibility from the public sphere as the most wealthy, aristocratic citizens might be.

In both of these chapters, women - particularly elite citizens - can be seen attempting to reconcile the reality of their behaviour with the ideological edict of invisibility in the public sphere, which became more acute in the fifth and fourth centuries. At this time, women's offerings moved inside Athena's temples and the andronymic - as well as denoting citizenship - aligned dedicators with their domestic role by identifying them in terms of their family relationships. The continued dedication of often expensive offerings, however, and the increased emphasis on displaying citizen status reveals a simultaneous reality of citizen women as both possessing status within their community and continuing to engage with it through the publicly visible practice of dedication. Offerings that reference paid work also disappear from the mid-fourth century (with the exception of Melinna's dedication), although this is perhaps more likely due to the nature of the evidence than a deliberate attempt to mask a dedicator's status as a public worker. However, women's engagement with property in general reveals that their behaviour was as much about appearing not to engage with the public as actually being excluded from it. Indeed, votive offerings themselves were a permissibly visible form of female disposal due to their legitimising religious context. Further, even women's commercial activity, although it took place outside of the home and is widely displayed in votive offerings, avoided formal engagement with the public sphere by being legally 'off the books'; this gave women's work an appearance of petty trade, despite substantial sums sometimes being involved, which perhaps helped it to seem less significant in its violation of gender ideology.

To conclude, the votive offerings dedicated on the Acropolis tell us three things about Athenian women: firstly, that female citizens had independent social status and were valued within their community; secondly, that all types of women had a variety of means for amassing property and the ability to (generally) extra-legally dispose of it in significant amounts - one of these courses of disposal being dedication itself; and thirdly, that this reality of practical agency within the public sphere needed to be mitigated and legitimised in order to be ideologically palatable. Indeed, it is this active attempt by most 
types of women to make themselves appear conspicuously invisible that hides them from our sources and makes them difficult to glimpse if we do not look a little deeper. 


\section{Catalogue A. Surviving votive offerings from female dedicators}

A1 AVI 0848; BAPD 8632

Dedicator: -a (no andronymic or demotic)

Black-figure plate showing Athena with painted inscription

c. $550 \mathrm{BC}$

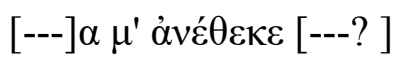

"[...] a dedicated me."

BAPD 8632; NM 2411; Boardman et al. 2004, 308.

A2 IG $\mathrm{I}^{3} 615 ; D A A 232$

Dedicator: Ergokleia (no andronymic or demotic)

Reason for dedication: aparche

c. 525-510 BC

Two fragments of marble pillar monument

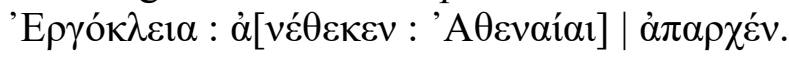

"Ergokleia dedicated [me] to Athena as an aparche."

$D A A$ 232; Dillon 2002, 15; Kaltsas and Shapiro 2008, 50 (image); Avramidou 2015, cat. 18.

\section{A3 IG $\mathrm{I}^{3} 555$}

Dedicator: Timagora (no andronymic or demotic)

c. 525-500 BC

Handle of wide, shallow bronze bowl, possibly a chernibeion

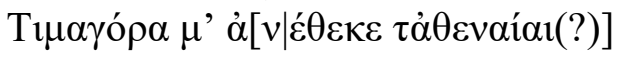

"Timagora dedicated me to Athena."

Kaltsas and Shapiro 2008, 59 (image); Avramidou 2015, cat. 8.

\section{A4 IG $\mathrm{I}^{3} 683 ; D A A 3$}

Dedicator: Iphidike (no andronymic or demotic)

c. $510-500 \mathrm{BC}$

Three fragments of marble column monument

Base for sculpture by Archermos (famous Chian sculptor)

'А

"Archermos the Chian made me. Iphidike dedicated me to Athena Protector of the City."

$D A A$ 3; Dillon 2002, 15; Kaltsas and Shapiro 2008, 52 (image); Avramidou 2015, cat. 20.

\section{A5 IG I $\mathrm{I}^{3} 656 ; D A A 81$}

Dedicator: $[\mathrm{Ph}]$ sakythe (no andronymic or demotic)

c. $510-500 \mathrm{BC}$

Two fragments of low marble base

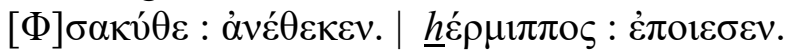

"[Ph]sakythe dedicated [me]. Hermippos made [me]."

$D A A$ 81; Dillon 2002, 15; Avramidou 2015, cat. 19. 
A5.5 IG I 609*

Dedicator: Chionis (no andronymic or demotic)

c. $510-500 \mathrm{BC}$

Base of three tripiods

Xíovis : ỏ $\lambda[-\longrightarrow-\dot{\alpha} v \varepsilon \dot{\varepsilon}] \theta \varepsilon \kappa \varepsilon v$.

"Chionis dedicated ---?"

Avramidou 2015, cat. 17.

A6 IG I $\mathrm{I}^{2} 677 ; D A A 201$

Dedicator: Myrrhine (father's name missing; deme: Phrearios)

c. $500 \mathrm{BC}$

Capital of marble_pillar monument

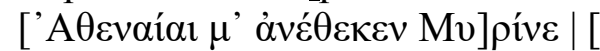

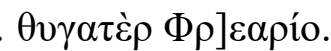

"Myrine, [daughter of ?, from Phr] earios, dedicated me to Athena."

DAA 201 (image); Avramidou 2015, cat. 27.

A7 IG $\mathrm{I}^{2} 678 ; D A A 224$

Dedicator: -e (no andronymic or demotic)

Reason for dedication: dekate

c. $500 \mathrm{BC}$

Three fragments of either a marble pillar monument (likely) or rectangular base

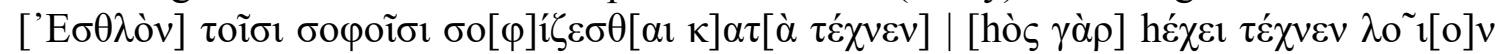

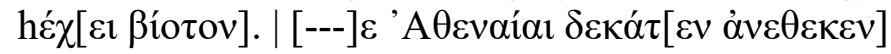

"It is good for the skilled to exercise their skill in accordance with their craft; for he who has a craft has a better life. [---]e dedicated a dekate to Athena."

$D A A 224$ (image).

A8 $\quad I G \mathrm{I}^{3} 546$

Dedicator: Phrygia (no andronymic or demotic)

c. $500 \mathrm{BC}$

Miniature bronze shield showing gorgeion

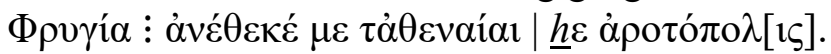

"Phrygia the bread-seller dedicated me to Athena"

van Straten 1981, 81; Dillon 2002, 16-17; Boardman et al. 2004, 302; Kaltsas and Shapiro 2008, 65 (image); Avramidou 2015, cat. 5.

A9 IG $\mathrm{I}^{3} 800 ; D A A 191$

Dedicator: Philea (uncertain) (andronymic: Chairedemos [uncertain]; demotic:

Athmonon)

Reason for dedication: dekate

c. $500-490 \mathrm{BC}$

Two fragments of marble pillar monument

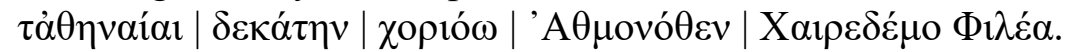

"Phileia, [daughter? Wife?] of Chairedemos from the region Athmonon to Athena as dekate."

DAA 191; Boardman et al. 2004, 277. 
A10 IG $\mathrm{I}^{3} 814 ; D A A 33$

Dedicator: Kalis (male or female name) (no andronymic or demotic)

Reason for dedication: dekate

c. $500-490 \mathrm{BC}$

Marble column monument

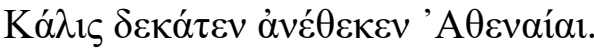

"Kalis dedicated a dekate to Athena."

DAA 33 (image); Dillon 2002, 15; Avramidou 2015, cat. 29.

A11 IG $\mathrm{I}^{3} 703 ; D A A 284$

Dedicator: Thotime (no andronymic or demotic)

Reason for dedication: aparche in fulfilment of vow

c. $500-490 \mathrm{BC}$

Two fragments of marble_pillar monument

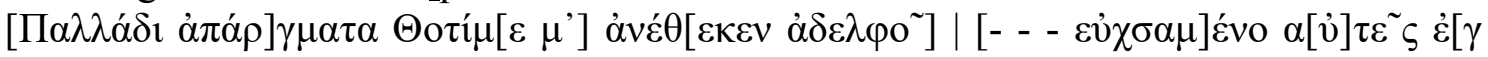
$\kappa \tau \varepsilon \alpha ́ v o v]$.

"Thotime dedicated me as aparche to Pallas for her brother... in accordance with her prayer, from her wealth."

DAA 284; Avramidou 2015, 22.

A12 IG $\mathrm{I}^{3} 565$

Dedicator: Kapanis (male or female name) (no andronymic or demotic)

Reason for dedication: dekate

c. $500-490 \mathrm{BC}$

Wide, shallow bronze bowl with handles

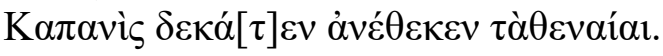

"Kapanis dedicated a dekate to Athena."

Kaltsas and Shapiro 2008, 60-1 (image); Avramidou 2015, cat. 10.

A13 IG $\mathrm{I}^{3} 572$

Dedicator: Myrto (no andronymic or demotic)

c. $500-490 \mathrm{BC}$

Vertical strap handle from bronze oinochoe

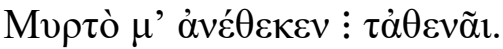

"Myrto dedicated me to Athena."

Kaltsas and Shapiro 2008, 64 (image); Avramidou 2015, cat. 13.

A13.5 IG I 577

Dedicator: Smikra (no andronymic or demotic)

c. $500-480$

Kylix

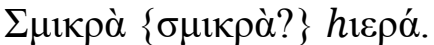

"Smikra [dedicated] an offering."

Avramidou 2015, cat. 16. 
A14 Unpublished; Kaltsas and Shapiro 2008, 54.

Dedicator: Peithylla (no andronymic or demotic)

c. $525-470 \mathrm{BC}$

Wide, shallow bronze bowl (lekanis-shaped)

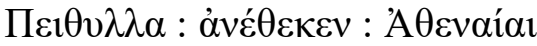

"Peithylla dedicated [me] to Athena."

Kaltsas and Shapiro 2008, 54 (image); Avramidou 2015, cat. 37.

A14.5 IG I 571

Dedicator: Himera (no andronymic or demotic)

c. $500-480 \mathrm{BC}$

Bronze oinochoe

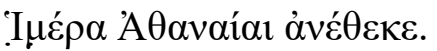

"Himera dedicated [me] to Athena."

Avramidou 2015, cat. 12.

A15 IG $\mathrm{I}^{3} 767 ; D A A 25$

Dedicator: Empedia (no andronymic or demotic)

Reason for dedication: dekate

c. $490 \mathrm{BC}$

Marble column monument

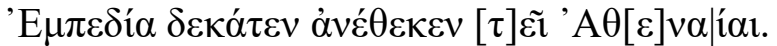

"Empedia dedicated a dekate to Athena."

DAA 25 (image); Dillon 2002, 15; Avramidou 2015, cat. 24.

\section{A16 IG $\mathrm{I}^{3} 560$}

Dedicator: Nikatta or Nika (no andronymic or demotic)

c. $500-480 \mathrm{BC}$

Section of rim from bronze phiale

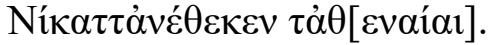

"Nik\{att\}a dedicated [me] to Athena."

Kaltsas and Shapiro 2008, 55 (image); Avramidou 2015, cat. 9.

\section{A17 IG $\mathrm{I}^{3}$ 700; DAA 93}

Dedicators: ?, Phyrne and Smikythe (no andronymic or demotic)

c. $500-480 \mathrm{BC}$

Two fragments of low marble base

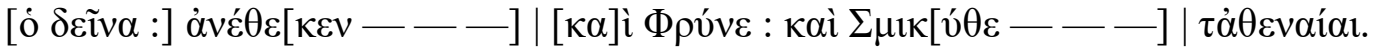

"?, and Phryne and Smikythe dedicated... to Athena."

$D A A$ 93; Dillon 2002, 15; Avramidou 2015, cat. 21. 
A18 IG I $\mathrm{I}^{3} 794 ; D A A 380$

Dedicator: Smikythe (no andronymic or demotic)

Reason for dedication: dekate

c. $490-480 \mathrm{BC}$

Complete limestone pedestal for marble basin

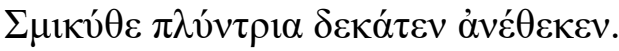

"Smikythe the washer-woman dedicated as a dekate."

$D A A$ 380; Dillon 2002, 15; Kaltsas and Shapiro 2008, 51 (image); Jim 2014, 140; Avramidou 2015, cat. 26.

A19 IG $\mathrm{I}^{3}$ 921; DAA 348; SEG 29.41

Dedicator: Kallikrite (no andronymic or demotic)

Reason for dedication: aparche

c. $490-480 \mathrm{BC}$

Two fragments of marble basin

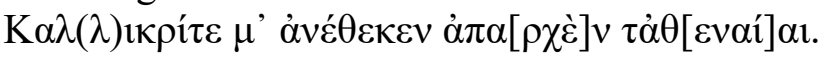

"Kallikrite dedicated me as an aparche to Athena."

$D A A 348$ (image); Dillon 2002, 15; Avramidou 2015, cat. 33.

A20 IG $\mathrm{I}^{3} 547$

Dedicator: Lysilla (no andronymic or demotic)

Reason for dedication: aparche

c. $500-475 \mathrm{BC}$

Small bronze disc, has been identified as cymbal due to hole for strap

$\Lambda v ́ \sigma 1 \lambda \lambda \alpha \dot{\alpha} \pi \alpha \rho \chi \dot{\varepsilon} v$ 'A $\theta \varepsilon v \alpha i ́ \alpha 1$.

"Lysilla [dedicated me] as an aparche to Athena."

Dillon 2002, 17; Kaltsas and Shapiro 2008, 53 (image); Jim 2014, ch. 5 n. 87; Avramidou 2015 , cat. 6 .

A21 IG $\mathrm{I}^{3} 813 ;$ DAA 258

Dedicator: Pheido (no andronymic or demotic)

c. $480 \mathrm{BC}$

Marble pillar monument

$\Phi \varepsilon 1 \delta o ̀ ~ \mu ’ ~ \alpha ́ v \varepsilon ́ \theta \varepsilon \kappa \varepsilon v$.

"Pheido dedicated me."

DAA 258; Dillon 2002, 15; Avramidou 2015, 28.

A22 IG $\mathrm{I}^{3} 536$

Dedicator: Glyke (no andronymic or demotic)

Reason for dedication: dekate

c. $480 \mathrm{BC}$

Bronze statue base

$\Gamma \lambda \hat{\kappa} \varepsilon \delta \varepsilon \kappa \alpha ́|\tau \varepsilon v \tau \dot{\alpha} \theta \varepsilon v \alpha i ́ \alpha|<1>$.

"Glyke [dedicated] a dekate to Athena."

Dillon 2002, 13; Jim 2014, 166-7; Avramidou 2015, cat. 1. 


\section{A23 IG $\mathrm{I}^{3} 548$ bis}

Dedicator: Glyke (no andronymic or demotic)

Reason for dedication: dekate

c. $480 \mathrm{BC}$

Handle of bronze mirror

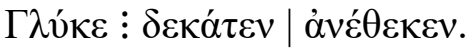

"Glyke dedicated a dekate."

Dillon 2002, 13; Jim 2014, 166-7; Avramidou 2015, cat. 7.

\section{A24 IG $\mathrm{I}^{3} 537$}

Dedicators: Chalchis and Thethis (no andronymic or demotic)

c. $480 \mathrm{BC}$

Decorated bronze base of figurine

X $\alpha \lambda \chi i \varsigma \varsigma \alpha \alpha i ̀ ~ \Theta \varepsilon ́ \theta ı \varsigma ~ A \theta \varepsilon \mid$.

"Chalchis and Thethis [dedicated me] to Athena."

Kaltsas and Shapiro 2008, 66 (image); Avramidou 2015, cat. 2.

A24.5 IG I 537

Dedicator: Klearete (no andronymic or demotic)

c. $480 \mathrm{BC}$

Bronze base

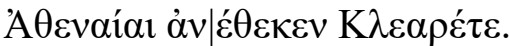

"Klearete dedicated [me] to Athena."

Avramidou 2015, cat. 3.

A25 IG $\mathrm{I}^{3}$ 934; DAA 369

Dedicator: Kallisto (father: Naukydes; no demotic)

Reason for dedication: aparche

c. $480-470 \mathrm{BC}$

Four fragments of elaborate marble basin

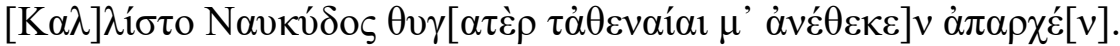

"Kallisto, daughter of Naukydos, dedicated me as an aparche to Athena."

$D A A 369$ (image); Dillon 2002, 17; Avramidou 2015, cat. 34.

\section{A25.5 IG I 574}

Dedicator: Smikythe (no andronymic or demotic)

Reason for dedication: dekate

c. $475 \mathrm{BC}$

Bronze hydria

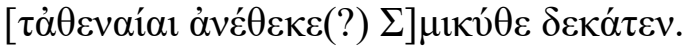

"Smikythe dedicated [me] as a dekate to Athena."

Avramidou 2015, cat. 15. 


\section{A26 IG $\mathrm{I}^{3} 540$}

Dedicator: Meleso (no andronymic or demotic)

Reason for dedication: dekate

c. $480-470 \mathrm{BC}$

Small bronze statue of Athena

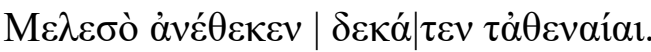

"Meleso dedicated [me] as a dekate to Athena."

Dillon 2002, 16 (image); Avramidou 2015, cat. 4.

A26.5 IG I 567

Dedicator: Meliteia (no andronymic or demotic)

Reason for dedication: dekate

c. $475-450 \mathrm{BC}$

Bronze lekane

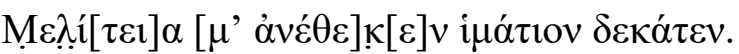

"Meli[tei]a dedicated me, a himation, as a dekate."

Avramidou 2015, cat. 11.

\section{A27 IG $\mathrm{I}^{3} 858 ; D A A 297$}

Dedicators: Aris[t]omache and Charikleia (father: Glaukinos; no demotic)

c. $470-450 \mathrm{BC}$

Marble pillar monument

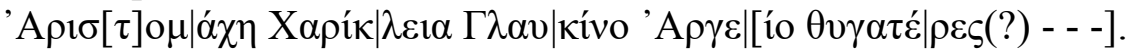

"Aristomarche and Charikleia daughters of Glaukinos the Argive."

$D A A$ 297; Dillon 2002, 17; Avramidou 2015, cat. 31.

\section{A28 IG $\mathrm{I}^{3} 857 ;$ DAA 298}

Dedicator: Mikythe (no andronymic or demotic)

Reason for dedication: dekate as fulfilment of vow

c. $470-450 \mathrm{BC}$

Marble pillar monument

Base for sculpture by artist Euphron (name attested on other large Acropolis dedications)

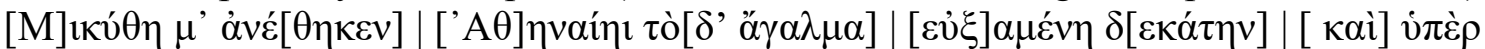

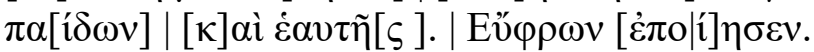

"Mikythe dedicated me as an agalma to Athena, having promised a dekate, on behalf of her children and herself. Euphron made me."

$D A A 298$ (image); Dillon 2002, 15; Avramidou 2015, cat. 30.

\section{A29 IG $\mathrm{I}^{3} 888 ; D A A 378$}

Dedicator: ? (husband: Eumelides; deme: Sphettios)

c. $450 \mathrm{BC}$

Marble pillar monument

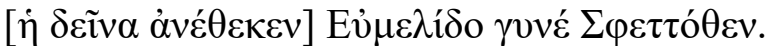

"[Name lost], wife of Eumelides of Sphettios [dedicated me]."

$D A A$ 378; Dillon 2002, 17; Avramidou 2015, cat. 32. 
A30 IG $\mathrm{I}^{3} 894 ; D A A 194$

Dedicator: ? (husband: Prepis; no demotic)

c. $430-420 \mathrm{BC}$

Marble pillar monument

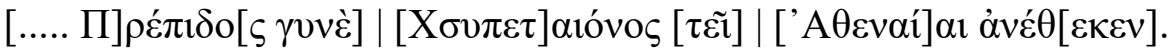

"The wife of Prepis dedicated [me] to Athena."

DAA 194; Dillon 2002, 17.

\section{A31 IG II $^{2} 4334$}

Dedicator: Melinna (no andronymic or demotic)

Reason for dedication: aparche

After c. $350 \mathrm{BC}$

Square marble base

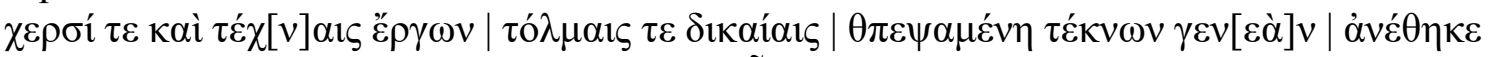

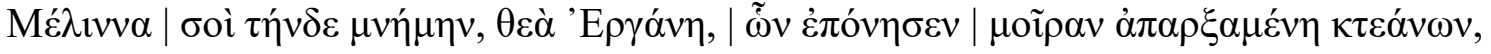
| $\tau \mu \tilde{\omega} \sigma \alpha \chi \alpha \dot{\rho} \rho ı \sigma \eta ́ v$.

"Melinna, who brought up her family of children by her handicraft and skill in work and justified daring, dedicated to you, goddess of Works, this aparche, making a first-offering of a portion of her property, honouring your favour to her."

Boardman et al. 2004, 278; Jim 2014, 139.

A32 IG II $^{2} 4326$

Dedicator: Meneia (no andronymic or demotic)

Reason for dedication: inspired by a vision

Mid- $4^{\text {th }}$ century

Unknown object

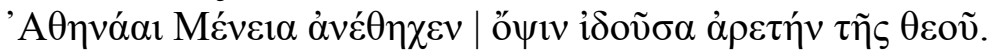

"Meneia has dedicated this to Athena, having seen the arete of the goddess in a vision." van Straten 1981, 77.

*Avramidou's article was only discovered at a late stage, so these items have been added to the catalogue as sub-numbers in order to avoid re-numbering all catalogue items. 


\section{Catalogue B. Temple inventory entries attesting votive offerings from female dedicators}

The date given is the year of the inventory, not of the dedication. Text from $I G$ and translations from Harris 1995.

B1 IG $\mathrm{I}^{3} 341$, line 6

Dedicator: Paapis E- (no andronymic or demotic)

406/5 BC

Gold phiale

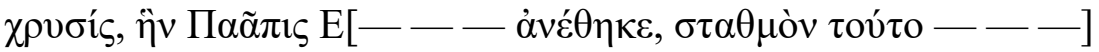

"A gold phiale, which Paapis E- dedicated; weight of this: --- dr."

Harris V.346

B2 IG II ${ }^{2} 1388$, lines 24-6

Dedicator: Kleostrate (father: Nikeratos; no demotic)

405/4 BC

Silver incense burner with bronze supports

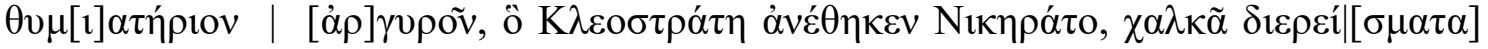

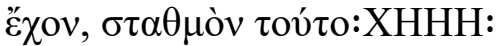

"A silver incense-burner, which Kleostrate, daughter of Nikeratos, dedicated, having bronze supports; weight of this: $1300 \mathrm{dr} . "$

Harris V.274

B3 IG II ${ }^{2} 1388$, lines 70-1

Dedicator: Axiothea (husband: Sokles; no demotic)

402/1 BC

Gold_ring

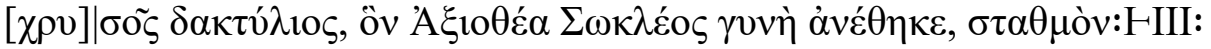

"A gold ring, which Axiothea, wife of Sokles, dedicated; weight: 1 dr. 3 ob."

Harris V.148

B4 IG $\mathrm{II}^{2} 1388$, lines 37-9

Dedicator: Aristomache (father: Aristokles; no demotic)

402/1 BC

Gold olive-wreath

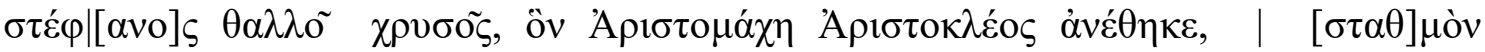

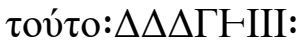

"A gold olive-wreath, which Aristomache, daughter if Aristokles, dedicated, weight of this: 36 dr. 3 ob."

Harris V.424 
B5 IG II ${ }^{2} 1400$, lines 65-71

Dedicators: Kleito and Dexilla (Kleito's husband: Aristokrates, son of Oulis, son of Kimon; no demotic. Dexilla: no andronymic or demotic)

Beginning 4th century BC

Painted box containing gold and silver jewellery, and glass and precious stones set in gold and silver

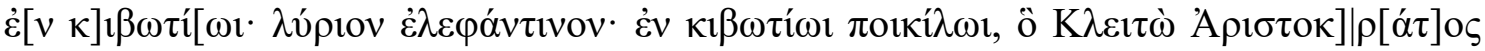

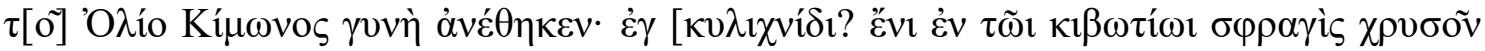

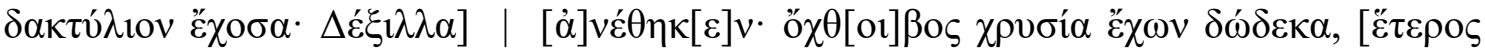

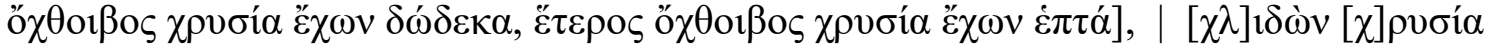

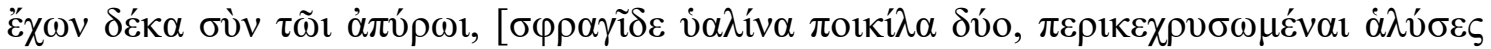

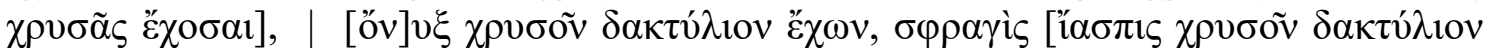

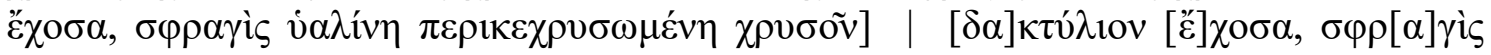

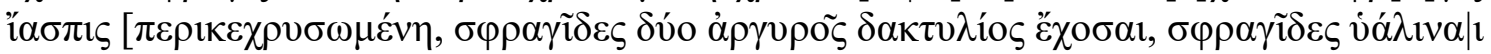

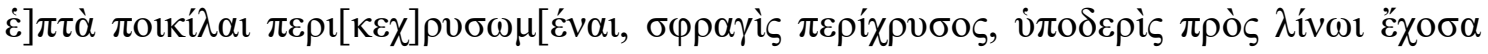
.......]

"In a painted box, which Kleito, wife of Aristokrates, son of Oulios, son of Kimon, dedicated, in which box there is a container in which there is a sealstone set in a gold ring, which Dexilla dedicated. A neckband having 12 golf pieces on it, and another having 7 gold pieces. A choker having 10 gold pieces including some unfired. Two coloured glass seals having gold chains, an oxyn having a gold ring, a jasper seal having a gold ring, a glass seal set in gold having a gold ring, a jasper seal set in gold, two seals having silver rings, seven coloured glass seals set in gold, a seal set in gold, a necklace with ---"

Harris II.37

B6 IG II ${ }^{2} 1388$, lines 79-80 and $I G \mathrm{II}^{2}$ 1400, lines 64-5

Dedicator: Thaumarete (husband: Timonides; no demotic)

398/7 BC

Box containing ivory lyre and plectrum

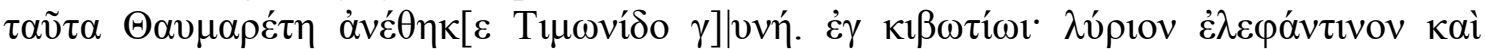
$\pi \lambda \tilde{\eta} \kappa \tau \rho \circ \nu[\hat{\eta} \lambda \varepsilon \varphi \alpha \nu \tau \omega \mu \dot{\varepsilon}] \mid$ vov $\xi u ́ \lambda \iota v o v$.

"These things Thaumarete, wife of Timonides, dedicated; in a box: an ivory lyre and ivory plectrum."

Harris II.71

B7 IG $\mathrm{II}^{2} 1388$, lines 27-8

Dedicator: Polyippe (father: Meleteon of Acharnai)

398/7 BC

Two gold bracelets

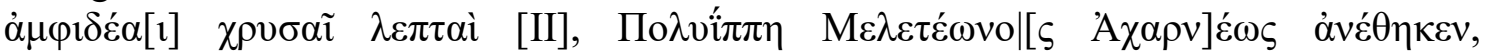

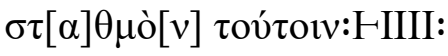

"2 fine gold bracelets, which Polyippe, daughter of Meleteon of Acharnai, dedicated; weight of these: $1 \mathrm{dr} .4 \mathrm{ob} . "$

Harris V.130 
B8 IG $\mathrm{II}^{2} 1388$, lines 55-7

Dedicator: Lysimache (son: Telemachos; no demotic)

398/7 BC

Silver phiale bearing gorgoneion

[ $\sigma \tau \alpha \theta \mu \mathrm{òv} . .$.$] | HFF :$

"A silver phiale, which Lysimache, mother of Telemachos, dedicated; on which is the gorgoneion; weight: $3+$ dr."

Harris V.317

B9 IG $\mathrm{II}^{2} 1400$, lines 51-2

Dedicator: Glyke (father: Archestratos; no demotic)

397/6 BC

Earrings, two gold rings, and a set stone

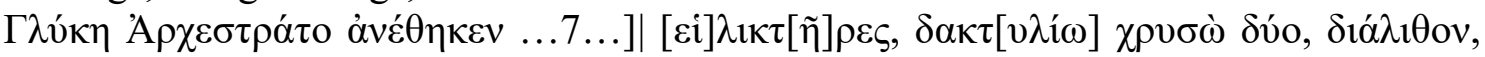

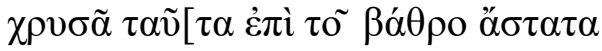

"Glyke, daughter of Archestratos, dedicated [---] earrings, two gold rings, a set stone, these gold things upon the base, unweighed."

Harris V.156

B10 IG $\mathrm{II}^{2}$ 1401, lines 31-2

Dedicator: Aristola (no andronymic or demotic)

397/6 BC

Silver phiale

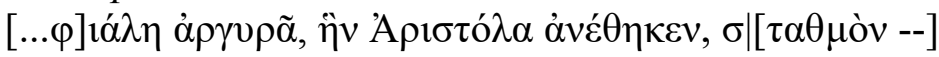

"A silver phiale, which Aristola dedicated; weight ---"

Harris V.311

B11 IG II ${ }^{2}$ 1409, line 14; JHS 58 (1938) 77

Dedicator: Aspasia (no andronymic or demotic)

395/4 BC

Gold tiara on wooden mount

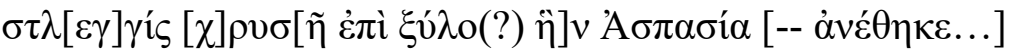

"1 gold tiara on a wooden mount, which Aspasia dedicated."

Harris V.421

B12 IG II $^{2} 1415$, lines 18-19

Dedicator: Smikythe (no andronymic or demotic)

$375 / 4 \mathrm{BC}$

Ivory cow figurine

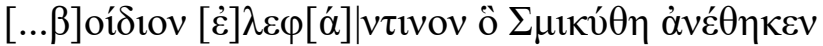

"Ivory cow, which Smikythe dedicated."

Harris V.101 
B13 IG II 2 1424a, lines 359-60

Dedicator: Philto (no andronymic or demotic)

375/4 BC

Unfired gold nugget

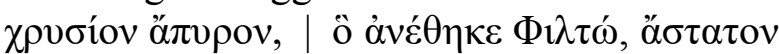

"An unfired gold nugget, which Philto dedicated, unweighed."

Harris VI.28

B14 IG II $^{2}$ 1424a, lines 360-1

Dedicator: Archedike (no andronymic or demotic)

374/3 BC

Gold ring

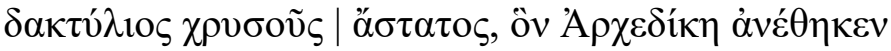

"A gold ring, unweighed, which Archedike dedicated."

Harris VI.23

B15 IG II ${ }^{2}$ 1424a, lines 355-6

Dedicator: Not provided (husband: Glaukon; no demotic)

374/3 BC

Silver phiale

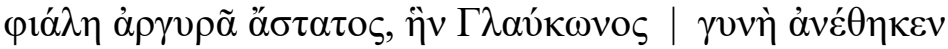

"A silver phiale, unweighed, which the wife of Glaukon dedicated."

Harris VI.34

B16 IG $\mathrm{II}^{2} 1424 \mathrm{a}$, lines 356-7

Dedicator: Demo (husband: Akoumenos; no demotic)

374/3 BC

Silver phiale

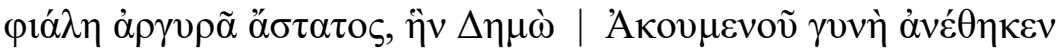

"A silver phiale, unweighed, which Demo, wife of Akoumenos, dedicated."

Harris VI.35

B17 IG II ${ }^{2}$ 1424a, lines 354-5

Dedicator: Eukoline (no andronymic or demotic)

374/3 BC

Silver phiale

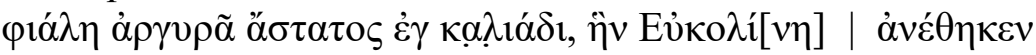

"A silver phiale, unweighed, in a case, which Eukoline dedicated."

Harris VI.36

B18

Dedicator: Aristoboule (no andronymic or demotic)

374/3 BC

Silver phiale

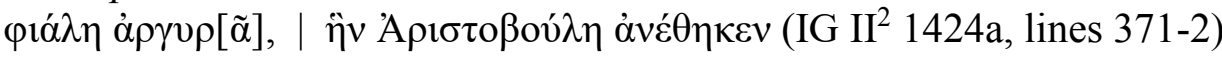

"A silver phiale, which Aristoboule dedicated."

Harris VI.37 
B19 IG II $^{2}$ 1429, lines 50-1

Dedicator: Kallikleia (husband: Thoukydides; no demotic)

374/3 BC

Gold wreath

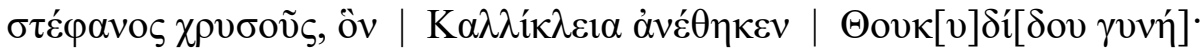

"A gold wreath, which Kallikleia dedicated, the wife of Thoukydides."

Harris VI.66

B20 IG $I^{2}$ 1472, lines 7-10

Dedicator: Nikylla (husband: Presbias; no demotic)

c. $319 / 8$ BC

Small silver phiale

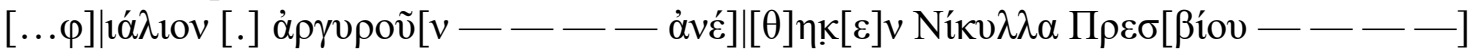

"A small silver phiale --- which Nikylla [wife of] Presbias dedicated."

Harris VI.39

B21 IG II $^{2} 1472$, lines 10-15

Dedicator: Nikagora (husband: Philistides; demotic: Paiania)

c. $319 / 8 \mathrm{BC}$ (the inscription shows that this object was dedicated by Nikagora in or before $326 / 5 \mathrm{BC})$

Small silver phiale

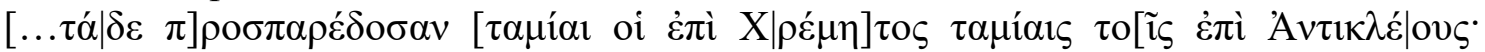

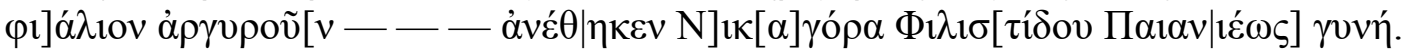

"The treasurers in the year of Chermes [326/5] made an additional contribution of these following things to treasuries in the year of Antikles (325/4): A small silver phiale --which Nikagora, wife of Philistides of Paiania, dedicated."

Harris VI.40

B22 IG $\mathrm{II}^{2} 1456$, lines 6-7

Dedicator: Phylarche (no andronymic or demotic)

314/3 BC

Small gold shield

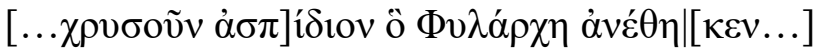

"A little gold shield, dedicated by Phylarche."

Harris VI.5 


\section{B23 IG II $^{2} 1456$, lines 27-32}

Dedicator: the priestess Phanostrate (father: Anak[---]; no demotic)

Possibly to celebrate tenure of priesthood

314/3 BC;

But, inscription shows that these objects were dedicated by Phanostrate by at least $341 / 0$ Object with five gold pieces attached

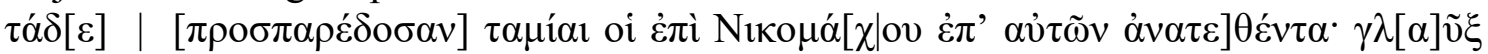

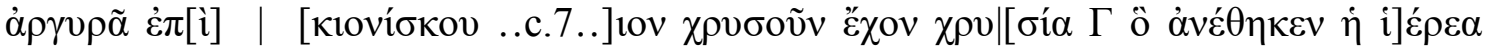

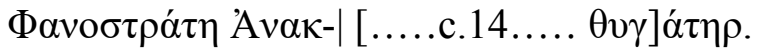

"The Treasurers in the year of Nikomachos [341/0] made an additional contribution of the following objects, which were dedicated in the period of their office. A silver owl on a small column; an object having five gold pieces which the Priestess Phantostrate, daughter of Anak[---], dedicated."

Harris VI.18

B24 IG II $^{2} 1456$, lines 14-16

Dedicator: Ionike (no andronymic or demotic)

After 314/3 BC

Embossed silver phiale

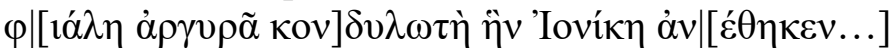

"A silver embossed phiale, which Ionike dedicated."

Harris VI.38

B25 IG II $^{2} 1489$, lines 19-22

Dedicator: the priestess [---]strate (no andronymic or demotic)

Possibly to celebrate tenure of priesthood

307/6 BC

Silver phiale

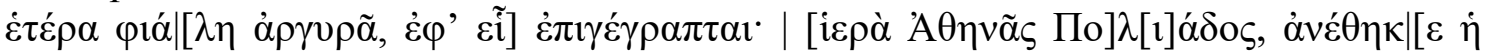

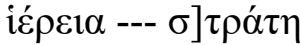

"Another silver phiale, on which is inscribed 'Sacred to Athena Polias'; the priestess [--]strate --- dedicated it."

Harris VI.47 


\section{Works Cited}

All primary source translations are taken from the Loeb series unless otherwise noted.

Acton, Peter. Poiesis: Manufacturing in Classical Athens. New York: Oxford University Press, 2014.

Aleshire, Sara. The Athenian Asklepieion: The People, their Dedications, and the Inventories. Amsterdam: J. C. Gieben, 1989.

Avramidou, Amalia. "Women Dedicators on the Athenian Acropolis and their Role in Family Festivals: The Evidence for Maternal Votives between 530-450 BCE." Cahiers "Mondes Anciens" 6 (2015): 1-29.

Beard, Mary. "Adopting an Approach II.” In Looking at Greek Vases, edited by Tom Rasmussen and Nigel Spivey, 12-26. Cambridge: Cambridge University Press, 1991.

Blok, Josine. 'Becoming Citizens: Some Notes on the Semantics of 'Citizen' in Archaic Greece and Classical Athens." Klio 87 no. 1 (2005): 7-40.

Citizenship in Classical Athens. Cambridge: Cambridge University Press, 2017.

“Perikles' Citizenship Law: A New Perspective.” Historia 58, no. 2 (2009): 141170.

Blundell, Sue. Women in Ancient Greece. Cambridge, MA: Harvard University Press, 1995.

Boardman, John et al. "Greek Dedications." In Vol. 1 of Thesaurus Cultus et Rituum Antiquorum, 269-318. Los Angeles: The J. Paul Getty Museum, 2004.

Borgers, Olaf. "Religious Citizenship in Classical Athens.” BABESCH 83 (2008): 73-97.

Bremmer, Jan. "Plutarch and the Naming of Greek Women." AJP 102, no. 4 (Winter, 1981): 425-6.

Brock, Roger. "The Labour of Women in Classical Athens." CQ 44, no. 2 (1994): 336346.

Burton, Joan. "Women's Commensality in the Ancient Greek World." $G \& R$ 45, no. 2 (Oct. 1998): 143-165.

Cohen, David. "Seclusion, Separation, and the Status of Women in Classical Athens." $G \& R, 36$ no. 1 (Apr., 1989): 3-15.

"Tyranny or the Rule of Law? Democratic Participation in Legal Institutions in Athens." In A Companion to Greek Democracy and the Roman Republic, edited by Dean Hammer. Chichester: Wiley Blackwell, 2015. 
"Women, Property and Status in Demosthenes 41 and 57." Dike 1 (1998): 53-61.

Connelly, Joan. Portrait of a Priestess: Women and Ritual in Ancient Greece. Princeton: Princeton University Press, 2007.

Cox, Cheryl Anne. Household Interests: Property, Marriage Strategies, and Family Dynamics in Ancient Athens. Princeton, NJ: Princeton University Press, 1998.

Davidson, James. "Bodymaps: Sexing Space and Zoning Gender in Ancient Athens." G\&H 23, no. 3 (Nov. 2011): 597-614.

de Polignac, François. "Sanctuaries and Festivals." In A Companion to Archaic Greece, edited by Kurt Raaflaub and Hans van Wees, 427-443. Malden, MA: WileyBlackwell, 2009.

de Ste. Croix, G. E. M. "Some Observations on the property Rights of Athenian Women." CR 20, no. 3 (Dec., 1970): 273-278.

Dillon, Mathew. Girls and Women in Classical Greek Religion. London and New York: Routledge, 2002.

Evans, Nancy. "Feasts, Citizens, and Cultic Democracy in Classical Athens." Ancient Society 34 (2004): 1-25.

Fantham, Elaine et al. Women in the Classical World. New York and Oxford: Oxford University Press, 1994.

Foxhall, Lin. "Female Inheritance in Athenian Law." Women and Property in Ancient Near Eastern and Mediterranean Societies, conference proceedings edited by Deborah Lyons and Raymond Westbrook, 1-11. Washington D.C.: Harvard University's Center for Hellenic Studies, 2003. Url: https://chs.harvard.edu/CHS/article/display/1219 44.

"Household, Gender and Property in Classical Athens." CQ 39, no. 1 (1989): 22-

Garland, Robert. Introducing New Gods. London: Duckworth, 1992.

Goff, Barbara. Citizen Bacchae: Women's Ritual Practice in Ancient Greece. Berkeley: University of California Press, 2004.

Gomme, A. W. "The Position of Women in Athens in the Fifth and Fourth Centuries." CP 20, no. 1 (Jan., 1925): 1-25.

Gould, John. "Law, Custom and Myth: Aspects of the Social Position of Women in Classical Athens.” JHS 100, Centenary Issue (1980): 38-59.

Harris, Diane. The Treasures of the Parthenon and Erechtheion. Oxford: Oxford University Press, 1995. 
Harris-Cline, Diane. "Women and Sacred Property: The Evidence from Greek Inscriptions." Women and Property in Ancient Near Eastern and Mediterranean Societies, conference proceedings edited by Deborah Lyons and Raymond Westbrook, 1-11. Washington, D.C.: Harvard University's Center for Hellenic Studies, 2003. Url: https://chs.harvard.edu/CHS/article/display/1219

Harris, Edward. "Women and Lending in Athenian Society A 'Horos' Re-Examined." Phoenix 46, no. 4 (1992): 309-321.

Harrison, A. R. W. The Law of Athens. Vol. 1, The Family and Property. Oxford: Clarendon Press, 1968.

Humphreys, S. C. The Strangeness of Gods: Historical Perspectives on the Interpretation of Athenian Religion. Oxford: Oxford University Press, 2004.

Hurwitt, Jeffrey. The Athenian Acropolis. Cambridge: Cambridge University Press, 1999.

James, Sharon and Sheila Dillon. "Introduction." In A Companion to Women in the Ancient World, edited by Sharon James and Sheila Dillon, 1-3. Malden, MA: WileyBlackwell Publishing, 2012.

Jim, Theodora. Sharing with the Gods: Aparchai and Dekatai in Ancient Greece. Oxford: Oxford University Press, 2014.

Just, Roger. Women in Athenian Law and Life. London and New York: Routledge, 1989.

Kaltsas, Nikolaos and Alan Shapiro (eds). Worshiping Women: Ritual and Reality in Classical Athens. New York: Alexander S. Onassis Public Benefit Foundation (USA), 2008.

Kamen, Deborah. Status in Classical Athens. Princeton: Princeton University Press, 2013.

Karoglou, Kyriaki. Attic Pinakes: Votive Images in Clay. Oxford: Archaeopress, 2010.

Katz, Marilyn. "Ideology and 'The Status of Women' in Ancient Greece." History and Theory 31, no. 4 (1992): 70-97.

Keesling, Catherine. Monumental Private Votive Dedications on the Athenian Acropolis, Ca. 600-400 B.C. PhD thesis (Classical Art and Archaeology), The University of Michigan, 1995.

The Votive Statues of the Athenian Acropolis. Cambridge: Cambridge University Press, 2003.

Kennedy, Rebecca. Immigrant Women in Athens: Gender, Ethnicity, and Citizenship in the Classical City. New York: Routledge, 2014. 
Kosmopoulou, Angeliki. “'Working Women': Female Professionals on Classical Attic Gravestones." The Annual of the British School at Athens 96 (2001): 281-319.

Kron, Uta. "Priesthoods, Dedications and Euergetism: What Part did Religion Play in the Political and Social Status of Greek Women." In Religion and Power in the Ancient World, conference proceedings edited by Pontus Hellström and Brita Alroth, 139182. Uppsala: Uppsala Studies in Ancient Mediterranean and Near Eastern Civilizations, 1996.

Kuenen-Janssens, L. J. "Some Notes upon the Competence of the Athenian Woman to Conduct a Transaction." Mnemosyne 9, no. 3 (1941): 199-214.

Lambert, S. D. The Phratries of Attica. Ann Arbor: The University of Michigan Press, 1993.

Lefkowitz, Mary R. and Maureen B. Fant. Women's Life in Greece and Rome. London: Duckworth, 1982.

Levick, Barbara. "Women and Law." In A Companion to Women in the Ancient World, edited by Sharon L. James and Sheila Dillon, 96-106. Malden, MA: Wiley-Blackwell Publishing, 2012.

Lewis, David M. "Notes on Attic Inscriptions (II): XXIII. Who Was Lysistrata?" ABSA 50 (1955): 1-36.

Llewellyn-Jones, Lloyd. "House and Veil in Ancient Greece.” BSAS 15 (2007): 251-258.

Loraux, Nicole. The Children of Athena: Athenian Ideas about Citizenship and the Division between the Sexes. Translated by Caroline Levine. Princeton: Princeton University Press, 1993.

Meyer, Elizabeth. Metics and the Athenian Phialai-Inscriptions. Volume 208, Historia Einzelschriften. Stuttgart: Franz Steiner Verlag, 2010.

Nevett, Lisa. "Towards a Female Topography of the Ancient Greek City: Case Studies from Late Archaic.” G\&H 23 no. 3 (Nov., 2011): 576-596.

Omitowoju, Rosanna. "The Crime that Dare not Speak its Name: Violence against Women in the Athenian Courts." In The Topography of Violence in the Greco-Roman World, edited by Werner Riess and Garrett Fagan, 113-135. Ann Arbor: University of Michigan Press, 2016.

Osborne, Robin. "Law, the Democratic Citizen and the Representation of Women in Classical Athens." Past \& Present no. 155 (May 1997): 3-33.

Patterson, Cynthia. "Athenian Citizenship Law." In The Cambridge Companion to Ancient Greek Law, edited by Michael Gagarin and David Cohen, 267-89. Cambridge: Cambridge University Press, 2005. 
Pericles' Citizenship Law of 451-50 B.C. New York: Arno Press, 1981.

Pomeroy, Sarah. Goddesses, Whores, Wives, and Slaves: Women in Classical Antiquity. New York: Schocken Books, 1975.

"Women's Identity and the Family in the Classical Polis." In Women in Antiquity: New Assessments, edited by Richard Hawley et al., 111-21. Oxford: Taylor and Francis, 1995.

Raaflaub, Kurt. "The Transformation of Athens in the Fifth Century." In Democracy, Empire, and the Arts in Fifth-Century Athens, edited by Deborah Boedeker and Kurt A. Raaflaub, 15-41. Cambridge, MA: Harvard University Press, 1998.

Raubitschek, A. E. Dedications from the Athenian Acropolis: A Catalogue of the Inscriptions of the Sixth and Fifth Centuries B.C. Cambridge, MA: Archaeological Institute of America, 1949.

Rayo, Diane. Sappho's Lyre: Archaic Lyric and Women Poets of Ancient Greece. Berkeley C.A.: University of California Press, 1991.

Reeder, Ellen. "The Catalogue." In Pandora: Women in Classical Greece. Princeton: Princeton University Press, 1995.

Rhodes, P. J. A Commentary on the Aristotelian Athenaion Politeia. Oxford: Clarendon Press, 1981.

Richter, Donald C. "The Position of Women in Classical Athens." CAMWS 67, no. 1 (Oct. - Nov., 1971): 1-8.

Ridgway, Brunilde Sismondo. "Ancient Greek Women and Art: The Material Evidence." AJA 91, no. 3 (Jul. 1987): 399-409.

Rouse, W. H. D. Greek Votive Offerings. Cambridge: Cambridge University Press, 1902.

Sealey, Raphael. Women and Law in Classical Athens. Chapel Hill and London: The University of North Carolina Press, 1990.

Schaps, David. Economic Rights of Women in Ancient Greece. Edinburgh: Edinburgh University Press, 1979.

"The Woman Least Mentioned: Etiquette and Women's Names." $C Q 27$, no. 2 (1977): 323-330.

Scheidel, Walter. "Real Slave Prices and the Relative Cost of Slave Labour in the GrecoRoman World." AS 35 (2005): 1-17.

Sommerstein, Alan. Talking about Laughter: And Other Studies in Greek Comedy. Oxford: Oxford University Press, 2009. 
Sourvinou-Inwood, Christiane. "Male and Female, Public and Private, Ancient and Modern." In Pandora, edited by Ellen Reeder, 111-120. Princeton: Princeton University Press, 1995.

Studies in Girls' Transitions: Aspects of the Arkteia and Age Representation in Attic Iconography. Athens: Kardamista, 1988.

Todd, S.C. The Shape of Athenian Law. Oxford: Clarendon Press, 1993.

van Straten, F. “Gifts for the Gods.” In Faith, Hope and Worship, edited by H. S. Versnel, 65-151. Leiden: E. J. Brill, 1981.

'Votives and Votaries in Greek Sanctuaries.' In Oxford Readings in Greek Religion, edited by R. Buxton, 191-225. Oxford: Oxford University Press, 2001.

van Wees, Hans. "The Invention of the Female Mind: Women, Property and Gender Ideology in Archaic Greece." Women and Property in Ancient Near Eastern and Mediterranean Societies, conference proceedings edited by Deborah Lyons and Raymond Westbrook, 1-26. Washington D.C.: Harvard University's Center for Hellenic amidStudies, 2003. Url: https://chs.harvard.edu/CHS/article/display/1219

Vlassopoulos, Kostas. "Athenian Slave Names and Athenian Social History.” ZPE Bd. 175 (2010): 113-144.

Wagner, Claudia. "The Worship of Athena on the Athenian Acropolis: Dedications of Plaques and Plates." In Athena in the Classical World, edited by Susan Deacy and Alexandra Villing, 95-104. Leiden: Brill, 2001.

Wagner-Hasel, Beate. "Women's Life in Oriental Seclusion? On the History and Use of a Topos." In Sex and Difference in Ancient Greece and Rome, edited by Mark Golden and Peter Toohey, 241-252. Edinburgh: Edinburgh University Press, 2003.

Whitehead, David. The Demes of Attica, 508/7-ca.250 B.C.: A Political and Social Study. Princeton, New Jersey: Princeton University Press, 1986.

Winters, T. F. “Kleisthenes and Athenian Nomenclature.” JHS 113 (1993): 162-165. 